Cornell University Law School Scholarship@Cornell Law: A Digital Repository

$11-2016$

\title{
Don't End or Audit the Fed: Central Bank Independence in an Age of Austerity
}

Neil H. Buchanan

George Washington University Law School

Michael C. Dorf

Cornell Law School, michaeldorf@cornell.edu

Follow this and additional works at: http://scholarship.law.cornell.edu/facpub

Part of the Banking and Finance Law Commons, and the Law and Economics Commons

\section{Recommended Citation}

Neil H. Buchanan and Michael C. Dorf, "Don't End or Audit the Fed: Central Bank Independence in an Age of Austerity," 102 Cornell Law Review (2016)

This Article is brought to you for free and open access by the Faculty Scholarship at Scholarship@Cornell Law: A Digital Repository. It has been accepted for inclusion in Cornell Law Faculty Publications by an authorized administrator of Scholarship@Cornell Law: A Digital Repository. For more information, please contact jmp8@cornell.edu. 


\title{
DON'T END OR AUDIT THE FED: CENTRAL BANK INDEPENDENCE IN AN AGE OF AUSTERITY
}

\author{
Neil H. Buchanan $\dagger^{\ddagger}$ \&ichael C. Dorf $\ddagger$
}

The Federal Reserve (the Fed) is the central bank of the United States. Because of its power and importance in guiding the economy, the Fed's independence from direct political influence has made it a target of ideologically motivated attacks throughout its history, with an especially aggressive round of attacks coming in the wake of the 2008 financial crisis and ongoing today. We defend Fed independence. We point to the Fed's exemplary performance during and after the 2008 crisis, and we offer the example of a potential future crisis in which Congress fails to increase the debt ceiling to show how the Fed's independence makes it the only entity that can minimize the damage during crises (both marketdriven and policy-induced). We further argue that the Fed's independence is justtfied to prevent self-dealing by politicians, even when no crisis is imminent. Although the classic justification for Fed independence focuses on the risk that political actors will keep interest rates lower than appropriate for the long-term health of the economy, we show that Fed independence addresses the risk of self-dealing and other pathologies even when, as now, political actors favor tighter monetary policy than appropriate for the long-term health of the economy.

INTRODUCTION $\ldots \ldots \ldots \ldots \ldots \ldots \ldots \ldots \ldots \ldots \ldots \ldots \ldots$

I. AN INDEPENDENT CENTRAL BANK: THE STRUCTURE AND POWERS OF THE FED . .................... 12

A. Structure of the Fed ................. 15

B. Powers of the Fed $\ldots \ldots \ldots \ldots \ldots \ldots \ldots \ldots, 16$

$\dagger$ Professor of Law, The George Washington University Law School, and Senior Fellow at the Taxation Law and Policy Research Institute, Monash University.

$\ddagger$ Robert S. Stevens Professor of Law, Cornell Law School. The authors thank Sherry Colb, Peter Conti-Brown, Cynthia Farina, Robert Hockett, Martin Lederman, Dina Mishra, Saule Omarova, Steven Shiffrin, Lawrence Solum, Jed Stiglitz, Lynn Stout, Charles Whitehead, David Zaring, and the participants in the Georgetown Constitutional Law Colloquium for helpful comments and conversations. Zachary Baum, Chelsea Kirkpatrick, Justin Mungai Ndichu, Neela Pack, and Christina Reda provided excellent research assistance. 
C. Why Is the Fed Independent, and What Does That Entail?......................... 21

II. CRITICISMS OF THE FED ................... 25

A. Statutory Authority................. 25

B. Transparency $\ldots \ldots \ldots \ldots \ldots \ldots \ldots \ldots, 30$

C. Substantive Priorities ................. 35

III. How THE FED SAVED THE ECONOMY, AND WHY IT

Might Have To Do So AgAin .............. 43

A. The Fed, the Existential Crisis of 2008-09, and the Aftermath ..................... 44

B. The Debt Ceiling and the President's Options During a Standoff .................... 51

C. The Dangers of Requiring the Fed to Use Its Full Powers ....................... 59

IV. JUSTIFYING FED INDEPENDENCE $\ldots \ldots \ldots \ldots \ldots \ldots \ldots, 63$

A. From Expertise to Self-Dealing........... 65

B. Pathology and Spandrels ............... 73

C. An Insider/Outsider Role ............... 79

CONCLUSION $\ldots \ldots \ldots \ldots \ldots \ldots \ldots \ldots \ldots \ldots \ldots, 83$

\section{INTRODUCTION}

During the financial crisis of 2008 and for much of the deep recession that followed, the Board of Governors of the Federal Reserve System (the Fed) ${ }^{1}$ took crucial steps to prevent the United States and the global economy from falling into a depression. Elected officials also acted. The Bush administration quickly devised the Troubled Assets Relief Program (TARP), which Congress first rejected but then enacted. ${ }^{2}$ In its first

1 Congress established the Federal Reserve System in 1913 to serve as the central bank of the United States. The Fed's key functions include formulating the country's monetary policy, maintaining the stability of the financial system, containdng systemic risks, regulating financial institutions, and providing various financial services to depository financial institutions and to the federal government. The Fed consists of a central, independent government agency (the Board of Governors), the Federal Open Market Committee (FOMC), and twelve regional Federal Reserve Banks. The Board of Governors and the FOMC effectuate monetary policy in pursuit of maximum employment, stable prices, and moderate longterm interest rates. See 12 U.S.C. \& 225a (2012); FED. RESERVE SYS., ROLES AND RESPONSIBILITIES OF FEDERAL RESERVE DIRECTORS 11 (2013), http://www.federalre serve.gov/aboutthefed/directors/pdf/roles_responsibilities_FINALweb013013. pdf [https://perma.cc/KE87-PB67].

2 The first version of the Emergency Economic Stabilization Act, debated in the House as H.R. 3997, was voted down 228-205 on September 29, 2008. See On Concurring in Senate Amendment with an Amendment: H.R. 3997 to Amend the Internal Revenue Code of 1986 to Provide Earnings Assistance and Tax Relief to members of the Uniformed Services, Volunteer Firefighters, and Peace Corps Volunters, and for Other Purposes, GovTRACK, https://www.govtrack.us/congress /votes/110-2008/h674 [https://perma.cc/K46D-CNZG] (vote tally). A second 
months in office, the Obama Administration sought and obtained a substantial package of spending aimed at stimulating the economy. ${ }^{3}$ And building on efforts begun by President Bush, President Obama rescued the U.S. automobile industry by arranging for federal government-backed debtor-in-possession financing for General Motors. ${ }^{4}$ Yet these efforts were modest in scale relative to those of the Fed. ${ }^{5}$ Moreover, after Republicans in Congress succeeded in limiting the size of the fiscal stimulus program such that it was too small from the outset, ${ }^{6}$ politicians of both parties too quickly set their sights on deficit reduction. ${ }^{7}$ Tea Party-affiliated congressional Repub-

version, H.R. 1424, passed the Senate on October 1, 2008 and the House 263-171 on October 3, 2008. See H.R. 1424 (110th): Paul Wellstone Mental Health and Addiction Equity Act of 2007, GOVTRACK, https://www.govtrack.us/congress/ votes/1 10-2008/h681 [https://perma.cc/GF6P-E8EV] (vote tally for bill creating TARP).

3 See American Recovery and Reinvestment Act of 2009, Pub. L. No 111-5, 123 Stat. 115 (2009).

4 See In re Gen. Motors Corp., 407 B.R. 463, 480 (Bankr. S.D.N.Y. 2009); CONG. OVERSIGHT PANEL, SEPTEMBER OVERSIGHT REPORT: THE USE OF TARP FUNDS IN THE SUPPORT AND REORGANIZATION OF THE DOMESTIC AUTOMOTIVE INDUSTRY 4-19 (2009), http://www.gpo.gov/fdsys/pkg/CHRG-11 1shrg51964/html/CHRG-111 shrg51964.htm [https://perma.cc/8J62-GD9S]; U.S. DEP'T OF THE TREASURY, AGENCY FinANCIAL REPORT: FISCAL YEAR 2009 144-49 (2009), http://www.treasury. gov/about/organizational-structure/offices/Mgt/Documents/09AFR_Treasury_ Tagged_07.pdf [https://perma.cc/T5NU-TTNL]; PRESIDENT'S AUTO TASK FORCE, OBAMa ADMINISTRATION NEW PATH TO VIABILTTY FOR GM \& CHRYSleR 2-3, https:// www.whitehouse.gov/assets/documents/Fact_Sheet_GM_Chrysler_FIN.pdf [https://perma.cc/72UP-KR6U]; Brent J. Horton, The TARP Bailout of GM: A Legal, Historical, and Literary Critique, 14 TEX. REV. L. \& POL. 217, 249 (2010).

5 Monetary policy was roughly an order of magnitude larger than fiscal policy. See generally CONG. OVERSight PANEL, MARCh Oversight REPORT: THE Final REPORT OF THE CONGRESSIONAL OVERSIGHT PANEL 162-64 (2011), http://www.gpo. gov/fdsys/pkg/CHRG-1 12shrg64832/pdf/CHRG-112shrg64832.pdf [https:// perma.cc/EH46-G6ZX] (quantifying measures taken by the Fed); OFFICE OF THE SPECIAL INSPECTOR GEN. FOR THE TROUBLED ASSET RELIEF PROGRAM, SIG-QR-09-03, GUARTERLY REPORT TO CONGRESS 4, 38, 140, 152, 156 (2009), http://www.sigtarp. gov/Quarterly\%20Reports/July2009_Quarterly_Report_to_Congress.pdf [https:/ /perma.cc/R44J-WZ6U] (quantifying TARP assistance and Fed programs).

6 See, e.g., Paul Krugman, Opinion, Franklin Delano Obama?, N.Y. Times (Nov. 10, 2008), http://www.nytimes.com/2008/11/10/opinion/10krugman. html [https://perma.cc/WEP6-CLED]; Paul Krugman, Opinion, Let's Get Fiscal, N.Y. TIMES (Oct. 16, 2008) http://www.nytimes.com/2008/10/17/opinion/17 krugman.html [https://perma.cc/T24W-4XVF]; Lawrence Summers, Opinion, Mr. Obama's Stimulus Plan Must Aim for Long-Term Results, WASH. POST (Dec. 28, 2008), http://www.washingtonpost.com/wp-dyn/content/article/2008/12/26/ AR2008122601299.html?nav=HCmoduletmv [https://perma.cc/S243-3FDJ] ("In this crisis, doing too little poses a greater threat than doing too much.").

7 See Budget Committee Mid-Session Hearings Fiscal Year 2014: Hearing on the Impact of Poltical Uncertainty on Jobs and the Economy Before the S. Comm. on the Budget, 113th Cong. 751 (2013) (testimony of Chad Stone, Chief Economist, Center on Budget and Policy Priorities), https://www.gpo.gov/fdsys/pkg/CHRG113shrg85902/pdf/CHRG-1 13shrg85902.pdf [https://perma.cc/VC5X-4LA5]; 
licans repeatedly threatened not to raise the debt ceiling-and thus raised the specter of a first-ever default by the government of the United States-in order to obtain deep cuts in government spending. ${ }^{8}$ With the political system thus deploying fiscal policy at first too timidly and then counterproductively, it was left to the Fed to steer the economy through recovery via monetary policy.

The Fed answered the call. In the early days of the crisis, the Fed interpreted its statutory mandate to permit bailouts of key firms, ${ }^{9}$ and for years thereafter the Fed kept real inter-

Spend Less, Owe Less, Grow the Economy: Hearing Before the Joint Econ. Comm. 112th Cong. (2011) (testimony of Chad Stone, Chief Economist, Center on Budget and Policy Priorities) https://www.gpo.gov/fdsys/pkg/CHRG-112shrg67929/ pdf/CHRG-1 12shrg67929.pdf [https://perma.cc/8TY4-Z7VJ]; Neil H. Buchanan, Good Deficits: Protecting the Public Interest from Deficit Hysteria, 31 VA. TAX REv. 75, 78 (2011) [hereinafter Buchanan, Good Deficits]; Neil H. Buchanan, Finally, Prominent Economists Are Admitting that the Policy Debate Should Not Focus on the Debt and Deficit: The Folly of Thinking Too Far Ahead, JUSTICIA.COM: VERDICT (Jan. 31, 2013), https://verdict.justia.com/2013/01/31/finally-prominent-economists-are-admitting-that-the-policy-debate-should-not-focus-on-the-debt-anddeficit [https://perma.cc/6NG5-FHPF]; Jon Hilsenrath, Course of Economy Hinges on Fight over Stimulus, WALL ST. J. (July 26, 2010, 12:01 AM), http:// www.wsj.com/articles/SB10001424052748704720004575376923163437134 [https://perma.cc/LXM7-VBS4] (quoting Rep. Paul Ryan rejecting government intervention); Christina Romer, Now Isn't the Time to Cut the Deficit, N.Y. TIMES (Oct. 23, 2010), http://www.nytimes.com/2010/10/24/business/24view.html ?_r=0 [https://perma.cc/Z9WR-UHCE].

8 See Neil H. Buchanan \& Michael C. Dorf, Bargaining in the Shadow of the Debt Ceiling: When Negotiating over Spending and Tax Laws, Congress and the President Should Consider the Debt Ceiling a Dead Letter, 113 COLUM. L. REV. SIDEBAR 32, 33 (2013) [hereinafter Buchanan \& Dorf, Bargaining in the Shadow]; Neil H. Buchanan \& Michael C. Dorf, Borrowing by Any Other Name: Why Presidential "Spending Cuts" Would Stll Exceed the Debt Ceiling, 114 COLUM. L. REv. SIDEBAR 26, 31-33 (2014) [herelnafter Buchanan \& Dorf, Borrowing by Any Other Name]; Neil H. Buchanan \& Michael C. Dorf, How to Choose the Least Unconstitutional Option: Lessons for the President (and Others) from the Debt Ceiling Standoff, 112 ColUM. L. REv. 1175, 1176 (2012) [hereinafter Buchanan \& Dorf, How to Choose]; Neil H. Buchanan \& Michael C. Dorf, Nullifying the Debt Ceiling Threat Once and for All: Why the President Should Embrace the Least Unconstitutional Option, 112 COLuM. L. REv. SIDEBAR 237, 240 (2012) [hereinafter Buchanan \& Dorf, Nullifying the Debt Ceiling Threat]; Jonathan Weisman, Republicans Pledge New Standoff on Debt Limit, N.Y. Times (May 15, 2012), http://www.nytimes.com/ 2012/05/16/us/politics/gop-pledges-new-standoff-on-debt-limit.html?_r=0 [https://perma.cc/K9MX-PPG3] (reporting House Speaker John Boehner's vow to oppose any increase in the debt celling unless it was offset by spending cuts).

9 Jose Gabilondo, Financial Hospitals: Defending the Fed's Role as a Market Maker of Last Resort, 36 SEATTLE U. L. REV. 731, 783-85 (2013); Thomas O. Porter, II, Note \& Comment, The Federal Reserve's Catch-22: A Legal Analysis of the Federal Reserve's Emergency Powers, 13 N.C. BANKING INST. 483, 485, 504-05 (2009). Contra Chris Isidore, Why They Let Lehman Die, CNN MONEY (Sept. 15, 2008, 4:54 PM), http://money.cnn.com/2008/09/15/news/companies/why_ bear_not_lehman/ [https://perma.cc/9L4V-K68Z]. 
est rates negative to flood the economy with essential liquidity. ${ }^{10}$

Yet the Fed was not rewarded with anything like universal praise. On the contrary, in recent years, Fed critics on both the left and the right have issued calls to "end" or "audit" the Fed. ${ }^{11}$ The substantive criticisms include the following: The Fed exercises power in excess of its statutory mandate, as when it created special purpose vehicles to bail out troubled firms during the early days of the financial crisis; ${ }^{12}$ it creates money "out of thin air," as when it pursued its policy of "quantitative easing" to stimulate the economy during the deep recession that followed that crisis; ${ }^{13}$ by design and in practice, it favors the

10 See generally Brett W. Fawley \& Christopher J. Neely, Four Stories of Quantitative Easing, 95 FED. RES. BANK ST. LOUIS REV. 51 (2013), https://research.st louisfed.org/publications/revlew/13/01/Fawley.pdf [https://perma.cc/6D4MQAA7] (describing central bank policies for providing monetary stimulus below the so-called zero lower bound of interest rates).

11 See, e.g., Federal Reserve Transparency Act of 2013, S. 209, 113th Cong. (2013) (calling for "a full audit of the Board of Governors of the Federal Reserve System and the Federal reserve banks by the Comptroller General of the United States"); RON PAUL, END THE FED 141 (2009) ("The Federal Reserve should be abolished because it is immoral, unconstitutional, impractical, promotes bad economics, and undermines liberty."); MARC LABONTE, CONG. RESEARCH SERV., R42079, FEDERAL RESERVE: OVERSIGHT AND DISCLOSURE ISSUES 6-12 (2016) thereinafter LABONTE, FEDERAL RESERVE: OVERSIGHT AND DISCLOSURE ISSUES] (describing recent enacted and proposed legislation concerning increased oversight and disclosure requirements for Fed activities); Chad Emerson, The Illegal Actions of the Federal Reserve: An Analysis of How the Nation's Central Bank Has Acted Outside the Law in Responding to the Current Financial Crisis, 1 WM. \& MARY BUS. L. REV. 109, 133 (2010) (arguing that the Fed should be subject to "a comprehensive and independent audit"); Lisa Lerer \& Julie Hirschfeld Davis, Romney Calls for Fed Audit as Party Mulls Platform Plank, BLoOMBerG (Aug. 20, 2012, 2:57 PM), http:// www.bloomberg.com/news/2012-08-20/romney-calls-for-fed-audit-as-partymulls-platform-plank.html [https://perma.cc/4CVS-EYK3] (quoting then-presidential candidate Mitt Romney saying he "would like to see the Fed audited").

12 See, e.g., Arthur W.S. Duff, Central Bank Independence and Macroprudential Policy: A Critical Look at the U.S. Financial Stability Framework, 11 BERKELEY Bus. L.J. 183, 212 (2014) (describing criticisms of the Fed's creation of a wholly owned limited liability company designed to purchase distressed assets from Bear Stearns); Emerson, supra note 11, at 129 ("[T]he Fed's attempt to conceal an illegal purchase of AIG assets through the use of a wholly-controlled LLC is, at best, a surreptitious attempt to circumvent the meaning of the Federal Reserve Act and, at worst, an intentional and purposeful violation of the law."); Alexander Mehra, Legal Authority in Unusual and Exigent Circumstances: The Federal Reserve and the Financial Crisis, 13 U. PA. J. Bus. L. 221, 236 (2010) (arguing that the creation of special purpose vehicles exceeded the Fed's authority under the Federal Reserve Act). But see Gabilondo, supra note 9, at 783-85 (arguing that the use of special purpose vehicles was legal); Porter, supra note 9, at 509 ("Section 13(3) grants the Fed expansive authority in 'unusual and exigent circumstances,' without requiring a stringent legal standard be met in order to respond to crises.") (footnote omitted).

13 See, e.g., PAUL, supra note 11, at 8-11 (characterizing Fed actions as the "Ben Bernanke printing press" that created "trillions in new money out of thin air" 
interests of banks over the interests of less powerful firms and individuals; ${ }^{14}$ and it tends to over-emphasize its inflation-fighting mandate over its employment-promoting mandate. ${ }^{15} \mathrm{Al}$ though critics on the left and right disagree about exactly what is wrong with the Fed's substantive priorities and performance, they offer similar procedural critiques: the Fed, they complain, is politically unaccountable and opaque.

Some of the foregoing criticisms are legitimate. ${ }^{16}$ Furthermore, if the Fed deserves praise for its response to the 2008 crisis and its aftermath, it must also share the blame for creating the crisis in the first place. Although it appropriately maintained low interest rates to sustain a weak economy during the administration of George W. Bush, ${ }^{17}$ it failed to provide the

without creating "any new wealth"); John P. Cochran, Fractional Reserve Banking and Central Banking as Sources of Economic Instability: The Sound Money Alternative, 11 INDIAN J. ECON. \& BUS. 543, 544-45 (2012) (arguing that "economic growth driven by money . . . creation is short term only; an artificial boom cannot last"); Chris Isidore, Gingrich: U.S. Should Reconsider the Gold Standard, CNN MONEY (Jan. 18, 2012, 4:06 PM), http://money.cnn.com/2012/01/18/news/economy/ gingrich_gold_standard/index.htm [https://perma.cc/8EKX-N3K3] (promoting the gold standard).

14 See Eric A. Posner \& Adrian Vermeule, Crisis Governance in the Administrative State: $9 / 11$ and the Financial Meltdown of 2008, 76 U. CHI. L. REV. 1613, 1625 (2009) ("Critics argued . . . that the bill favored the rich-the investment banks, their managers, their shareholders-at the expense of the taxpayer, while providing no relief to distressed homeowners ... . I). But cf. David Wessel, Inside Dr. Bernanke's E.R., WALL ST. J. (July 24, 2009, 12:13 PM), http://www.wsj.com/ articles/SB10001424052970204271104574292094147841898 [https:// perma.cc/852W-RKC2] (quoting former Federal Reserve Board Chairman Ben Bernanke saying, "I care about Wall Street for one reason and one reason only: because what happens on Wall Street matters to Main Street.").

15 See Marc Labonte, Cong. Research Serv., R41656, Changing the Federal RESERVE'S MANDATE: AN ECONOMIC ANALYSIS 9 (2013), http://fas.org:8080/sgp/crs/ misc/R4 1656.pdf [https://perma.cc/KZ93-XUA9] [hereinafter LABONTE, CHANGING THE FEDERAL RESERVE'S MANDATE]; Gabilondo, supra note 9, at 749-50; Daniel L. Thornton, The Dual Mandate: Has the Fed Changed Its Objective?, 94 FED. RES. BANK OF ST. LOUIS REV. 117, 117, 130 (2012), https://research.stlouisfed.org/ publications/review/12/03/117-134Thornton.pdf [https://perma.cc/94E7KY8L]; Press Release, Bd. of Governors of the Fed. Reserve Sys. (Jan. 25, 2012), http://www.federalreserve.gov/newsevents/press/monetary/20120125c.htm [https://perma.cc/7YWR-KWUT] (arguing that employment is driven primarily by nonmonetary factors).

16 But some are not. In particular, the contention that the Fed creates money out of thin air is an almost comically distorted description of how money comes into existence. Indeed, If one understands what money is and the role of a central bank, saying that money is created out of thin air is not a criticism but merely a colorfully misleading metaphor. See infra Part I.

17 The Fed's low interest rate policy has been criticized from the political right, as some observers claimed that low interest rates alone inexorably led to the housing bubble. See, e.g., Lawrence H. White, Federal Reserve Policy and the Housing Bubble, 29 CATO J. 115, 115-19 (2009) ("IT]he Federal Reserve's expansionary monetary policy supplied the means for unsustainable housing prices 
necessary oversight of systemically important financial institutions, which were especially in need of such oversight in a lowinterest rate environment. ${ }^{18}$

Nonetheless, even if some precisely targeted reforms of the Fed can be justified based on the experience of the recent past, calls to audit or end the Fed are quite misplaced. ${ }^{19}$ Although

and unsustainable mortgage financing."); John B. Taylor, How Government Created the Financial Crisis, WALL ST. J. (Feb. 9, 2009, 12:01 AM), http://www.wsj. com/articles/SB123414310280561945 [https://perma.cc/YU5S-3UBA] (arguing that Fed actions led to and worsened the crisis). With appropriate oversight, however, there is no reason to think that low interest rates-which were justified as a macroeconomic policy matter-would have led to the mortgage crisis.

18 The Financial Crisis and the Role of Federal Regulators: Hearing Before the H. Comm. on Oversight and Gov't Reform, 110th Cong. 15-16 (2008) (reporting former Fed Chair Alan Greenspan's admission that he had put too much faith in market forces); see also FIN. CRISIS IngUIRY COMM'N, THE FINANCIAL CRISIS IngUIRY REPORT: Final REPORT OF THE NATIONAL COMMISSION ON THE CAUSES OF THE FinanCIAL AND ECONOMIC CRISIS IN THE UNITED STATES 52-66 (2011), http://www.gpo.gov/ fdsys/pkg/GPO-FCIC/pdf/GPO-FCIC.pdf [https://perma.cc/VF2D-9N4R] (noting the lack of effective regulation and the failure of federal officials to identify systemic risk); Bryan J. Orticelli, Note, Crisis Compounded by Constraint: How Regulatory Inadequacies Impaired the Fed's Bailout of Bear Stearns, 42 CoNN. L. REV. 647, 650-51 (2009) (arguing that fragmented regulatory authority contributed to the Fed's inability to anticipate systemic risk). As Professor Saule Omarova observes, the very power to exempt financial institutions from Section 23A of the Federal Reserve Act, 12 U.S.C. \$ 371 1c (2006) (amended 2010), that some critics claim the Fed abused in bailing out firms, played a key role in creating the risky "shadow banking" regime in the lead-up to the crisis. See Saule T. Omarova, From Gramm-Leach-Bliley to Dodd-Frank: The Unfulfilled Promise of Section 23A of the Federal Reserve Act, 89 N.C. L. REv. 1683, 1702-29 (2011).

19 Campaigning as an economic populist (when not campaigning as a racist, misogynist, and xenophobe), Republican presidential candidate Donald Trump has repeated the calls by others in his party to "audit the Fed," but at least one commentator opined "that Trump's heart isn't really in it." Jeff Spross, Donald Trump is Shockingly Sane on the Federal Reserve, THE WEEK (Apr. 26, 2016), http://theweek.com/articles/620637/donald-trump-shockingly-sane-federalreserve [https://perma.cc/PQ2Y-FV3M]. Given the hyperbolic and opportunistic nature of Trump's policy pronouncements, we would not hazard a guess as to his true druthers, if he even has any. We would note, however, that Trump's signature contribution to public debate about the government debt was the one idea that may be more dangerous than subjecting the Fed to greater political control. Specifically, Trump suggested pressuring holders of Treasury securities to accept less than full payment, see Binyamin Appelbaum, Donald Trump's Idea to Cut National Debt: Get Creditors to Accept Less, N.Y. TIMES (May 6, 2016), http:// www.nytimes.com/2016/05/07/us/politics/donald-trumps-idea-to-cut-nation al-debt-get-creditors-to-accept-less.html?_r=2 [https://perma.cc/UA3U-H2P7], thus jeopardizing the credit rating of U.S. debt. Trump subsequently pretended not to have meant what he obviously said, but the incoherence of his explanation, see Neil H. Buchanan, The Trump Debt Repudiation Walk-Back Is Actually Funnier Than His First Insane Idea, DORF ON LAW (May 10, 2016, 7:35 AM), http:// www.dorfonlaw.org/2016/05/the-trump-debt-repudiation-walk-back-is.html [https://perma.cc/XD2A-JPS5], simply underscores that Trump has little understanding of economic policy. 
different in their details, ${ }^{20}$ at a minimum such proposals aim to curtail Fed independence, thus subjecting monetary policy to greater supervision by elected officials. ${ }^{21}$

Subjecting the Fed to close political oversight would likely have harmful, perhaps even disastrous, consequences. Any country or, as in the case of the European Union, transnational political unit, that maintains its own currency, needs a central bank that is independent of close political oversight in order to ensure that politicians do not manipulate the monetary system for short-term political gain at the risk of inflicting long-term economic damage. The classic worry is that incumbents will provide excessive economic stimulus in the months leading up to an election, even when the best economic analysis would call for tightening the spigot. ${ }^{22}$ Accordingly, although the Fed is a

20 Several bills have been proposed over the years calling for the Fed to be audited. See, e.g., Federal Reserve Transparency Act of 2015, S. 264, 114th Cong. (2015) (calling for "a full audit of the Board of Governors of the Federal Reserve System and the Federal reserve banks by the Comptroller General of the United States"); Federal Reserve Transparency Act of 2015, H.R. 24, 114th Cong. (2015) (same); Federal Reserve Transparency Act of 2014, H.R. 24, 113th Cong. (2014) (same); Federal Reserve Transparency Act of 2013, S. 209, 113th Cong. (2013) (same); see also Audit the Fed Act of 2013, H.R. 33, 113th Cong. (2013) (proposing reform of the manner in which the Comptroller General audits the Board of Governors); Bernie Sanders, To Rein in Wall Street, Fix the Fed, N.Y. TimEs (Dec. 23, 2015), http://www.nytimes.com/2015/12/23/opinion/bernie-sanders-torein-in-wall-street-fix-the-fed.html?_r=0 [https://perma.cc/NE3C-YFM7] ["We need to ... require the Government Accountability Office to conduct a full and independent audit of the Fed each and every year.").

21 We use the term "Independence" to connote the fact that the Fed does not answer directly to the president or to Congress, but not to suggest that, as currently structured, outside actors, including political actors, have no influence on the Fed. If meant to imply economic expertise divorced from other constraints, we agree with Peter Conti-Brown's assessment that "independence' . . . is a concept without much analytical content." PETER CONTI-BROWN, THE POWER AND INDEPENDENCE OF THE FEDERAL RESERVE xii (2016). The very complexity of the Fed's structure belies the image of the Fed as a single expert actor. See id. at 8 ("[T]he Fed is one of the most organizationally complex entities in the federal government ... [,] a 'they,' not an 'it [ " . . . "). We nonetheless find the term "independence" useful as a shorthand for the degree of autonomy from elected officials that the Federal Reserve system enjoys relative to typical federal agencies within the executive branch.

22 Even as he deconstructs the concept of Fed independence, Conti-Brown aptly summarizes the standard justification for it:

Fed independence is the separation, by statute, of the central bankers (specifically the Fed Chair) and the politicians (specifically the president) for purposes of maintaining low inflation.... [C]itizens in a democracy naturally prefer a prosperous economy. Politicians please us by giving us that prosperity, or at least trying to take credit for it. But when there is no prosperity to be had, politicians will resort to goosing the economy artificially by running the printing presses to provlde enough money and credit for all. The shortterm result is reelection for the politicians. The long-term result is 
creation of Congress rather than the Constitution itself, its independence can be justified with structural arguments similar to those typically offered to justify the independence of the Article III judiciary. Just as we cannot fully trust majoritarian politics to safeguard the constitutional rights of minorities, so we cannot trust venal politicians who have incentives timed to the political cycle to set monetary policy timed to the business cycle, all the while keeping in mind longer-term goals of growth and stability.

Ironically, however, in the current climate the harmful consequences of ending or auditing the Fed would not flow from the profligacy of politicians but from their foolish commitment to austerity. We need the Fed to be independent now in large part because subjecting it to close scrutiny by politically accountable actors would likely lead to unduly tight monetary policy. The Fed could no longer use monetary policy to counteract the baleful effects of ideologically driven tight fiscal policy. It would become part of the problem rather than part of the solution. Thus, even if the standard justification of the Fed's independence envisions the Fed tilting against too-loose monetary preferences among politicians, from an economic perspective, that justification applies equally when politician's preferences point in the opposite direction. Either way, the Fed serves as an important counterweight to politically motivated excess.

Is this reversal of the standard justification for central bank independence merely ironic, or does it raise a deeper problem of democratic accountability? So long as we can point to structural reasons for Fed independence, we have an answer to whatever "counter-majoritarian difficulty" such independence raises. ${ }^{23}$ But if our best justification for Fed independence is that politicians frequently make bad economic decisions, then the argument for Fed independence has no logical stopping point. Politicians make bad decisions in many areas. They under-invest in infrastructure; they deny climate change; they subsidize industries that harm human health; they enact criminal laws that destroy the lives of nonviolent offenders and their families; and so forth. If the risk of merely

Id. at 2 .

worthless money that wreaks havoc on our economic, social, and political institutions.

23 Alexander Bickel coined the term "counter-majoritarian difficulty" to describe the uneasy place of judicial review in a basically democratic system. ALEXANDER M. BICKEL, THE LEAST DANGEROUS BRANCH 16 (1962). We use it here to associate Fed independence with judicial independence. 
sub-optimal policies emerging from the political process justifies lodging power in expert agencies subject to little or no political oversight, then there will be very little room for governance by elected officials.

Can Fed independence be justified on grounds that do not also justify technocracy across the board? This Article argues that it can be.

Even though we currently live in an age in which surprisingly large numbers of policy makers are committed to economic austerity, the classic worry that political actors, if given the chance, will loosen credit when they ought to tighten it is real and could recur. Just as Vincent Blasi has argued that one ought to take a "pathological perspective" by designing constitutional rules governing free speech to protect against the worst of times, even if we usually live in good times, ${ }^{24}$ so too here, our government institutions regarding the economy should be constructed for the long run. And in the long run, political actors have incentives to manipulate monetary policy-and to try to intimidate the Fed in an attempt to change regulatory outcomes-to their advantage. Therefore, even if one disagrees with our economic analysis, and approves of austerity, the Fed's independence should be protected.

Our point is not simply that political actors will slight the long-term health of the economy for short-term gains. After all, political actors have incentives to focus on the short run with respect to many policy areas. Under-investment in infrastructure results in part from the fact that the benefits of infrastructure projects are spread out over many years or even decades. ${ }^{25}$ Likewise, addressing environmental problems may require current sacrifices to benefit future generations. ${ }^{26}$ If the shortsightedness of politicians were the only justification for Fed independence, then the argument really would amount to advocacy for technocracy tout court.

24 Vincent Blasi, The Pathological Perspective and the First Amendment, 85 COLUM. L. REV. 449, 449-50 (1985).

25 Infrastructure projects produce immediate benefits in the form of construction and ancillary jobs, but political considerations often distort the distribution of these benefits. For example, the government may pour money into building a new bridge in a powerful House member's district while neglecting needed rail improvements across many districts of less influential members. Moreover, the short-term benefits of infrastructure projects that are cost-justified in the long term may be smaller than the short-term benefits to current constituents of tax cuts or transfer payments.

26 See generally Neil $\mathrm{H}$. Buchanan, What Kind of Environment Do We Owe Future Generations?, 15 LEWIS \& CLARK L. REV. 339, 361-67 (2011). 
But political control of a central bank does not merely create a risk of shortsighted policy. It creates a risk of political self-dealing of the same sort that, in other contexts, is thought to justify departures from majoritarianism in the name of constitutional democracy. We have already mentioned the independent judiciary as guarantor of minority rights as a constitutionally enshrined example of this sort of institutional design. There are also subconstitutional examples, such as the use of special prosecutors to investigate and prosecute highranking executive officials and the use of politically-independent election commissions or ostensibly neutral courts to supervise the election process. Although these kinds of institutions have been implemented imperfectly in the United States, they rest on some of the same basic logic that justifies an independent Fed: incumbent elected officials ought not to be permitted to use the tools of government to gain unfair advantage in political contests. As John Hart Ely famously put the point in defending representation-reinforcing judicial review, counter-majoritarianism is easiest to justify when it serves to prevent the "ins" from exploiting their position to stay "in." 27

In addition, the sheer scale of the problems that a central bank must confront-encompassing the entire economy and posing risks of catastrophe such as hyperinflation or depression-and the speed with which it must act in the face of an emergency, call for an institution that can respond with alacrity. It might be thought that, following the logic of Federalist No. 70, the "Energy in the Executive" permits the president to oversee a central bank that can respond to financial crises rapidly and effectively. ${ }^{28}$ But because of the need to calm markets in troubled times, the Fed's policymaking board-indeed the Federal Reserve System as a whole-has sensibly been given policy independence, with political accountability ultimately deriving from the appointment and removal processes for Fed governors and regional bank presidents as well as Congress's power (which it has thus far wisely chosen not to exercise) to change the statutory mandate of the Fed (indeed, to dismantle the Fed entirely) at any time, subject to the reactions of the public and the financial markets to any meddling with the Fed's historical mandate and powers. ${ }^{29}$ Indeed, as we ex-

\footnotetext{
27 JOHN HART ELY, DEMOCRACY AND DISTRUST 101-04 (1980).

$28 C f$. THE FEDERALIST No. 70 (Alexander Hamilton) (arguing that an energetic, unitary executive promotes political accountability and sound management).

29 See supra note 1.
} 
plain at greater length below, in general and in times of crisis, the Fed's status as an entity that is not really a part of any of the three branches of government enables it to act as an independent counterparty to transactions with the more directly presidentially accountable (and thus politically manipulable) Treasury Department.

Although it is possible to imagine some of the current regulatory responsibilities of the Fed being reallocated to more directly accountable government agencies, independence contributes substantially to its ability to perform its key function as a central bank. As we argue in Part I, moreover, the interactions between the Fed's regulatory responsibilities and its mandate to conduct monetary policy writ large make sense of the Fed's current, broad portfolio.

This Article examines and responds to critiques of Fed independence in four parts. Part I presents a brief schematic overview of the structure and powers of the Fed. Part II catalogues the main criticisms of the Fed, distinguishing those that, if valid, could be addressed by modest statutory changes, from those that fundamentally challenge Fed independence. Part III explains how the Fed used its powers during the 2008 financial crisis and its aftermath to stabilize the economy, and how it might play an essential role in rescuing the economy in the event that the United States finds itself unable to pay its bills due to debt ceiling brinksmanship. Part IV then elaborates on the argument for Fed independence even in an era of austerity, explaining how an independent central bank fits in the overall constitutional design. We conclude by identifying a connection between contemporary anxiety about Fed independence and a longstanding but deeply problematic strain of Jeffersonian and Jacksonian populism dating to the earliest days of the American Republic.

AN INDEPENDENT CENTRAL BANK: THE STRUCTURE AND POWERS OF THE FED

The Federal Reserve System is the central bank of the United States. Like the Bank of England, the Bank of Japan, and the European Central Bank (as well as the national central banks that the latter institution replaced, including the Bundesbank and the Banque de France), the Fed was created to control the levers of monetary policy, most importantly including setting interest rates (and thus controlling the supply 
of money). ${ }^{30}$ In turn, these responsibilities for carrying out monetary policy at the macroeconomic level require that it have significant regulatory powers over the banking system.

The roots of the Fed date back to the earliest years of the Republic. The First Bank of the United States-the earliest predecessor to the Fed-served a number of vital functions, but it was not a central bank in the modern sense. ${ }^{31}$ In any event, its charter expired in 1811 , leaving the United States without a nationally chartered bank until 1816, when the Second Bank of the United States was created. ${ }^{32}$ In the intervening period, the United States nearly lost the War of 1812 , partly because its efforts were severely hampered by the lack of enthusiasm of state-chartered private banks for providing credit to the federal government. ${ }^{33}$ Consequently, following the war, President James Madison, whose Jeffersonian Republican Party had previously opposed the Bank, signed into law the bill creating the Second Bank of the United States. ${ }^{34}$ A few years later, Chief Justice John Marshall pithily alluded to this history in $\mathrm{McCul}$ loch v. Maryland, when he wrote that "a short experience of the embarrassments to which the refusal to revive [the First Bank] exposed the government, convinced those who were most prejudiced against the measure of its necessity, and induced the passage of the" law chartering the Second Bank. ${ }^{35}$

Nonetheless, President Andrew Jackson vetoed legislation that would have renewed the Second Bank's charter, offering populist and xenophobic reasons. ${ }^{36}$ In the nearly eight decades between the cessation of operations of the Second Bank and the establishment of the Federal Reserve, the federal government continued to develop a system to regulate banks. For example, during and after the Civil War, Congress passed a

30 See KEVIN D. HOOVER, APPLIED INTERMEdiATE MACROECONOMICS 624-25 (2012).

31 See generally Roger T. JOHNSON, Historical BEgINNINGS . . THE FEDERAL RESERVE 7-8 (Mary Jane Coyle \& Suzanne Cummings eds., 2010) (noting the basic and limited functions of the First Bank).

32 See Ralph C.H. Catterall, The Second Bank of the United States 1 (1903).

33 See id. ("The Second Bank of the United States owed its origin to the disasters of the war of $1812 \ldots$...).

34 See id. at 21 (noting that Madison signed the bill after vetoing a similar one the previous year).

3517 U.S. (4 Wheat.) 316, 402 (1819).

36 President Andrew Jackson, Veto Message Regarding the Bank of the United States, Yale LaW Sch.: The AVAlon PROJECT (July 10, 1832), http://avalon. law.yale.edu/19th_century/ajveto01.asp [https://perma.cc/6XPD-58BH]. 
series of banking statutes, ${ }^{37}$ which were most directly aimed at allowing the federal government to borrow money to finance the war effort, but which also established a national currency, created a national banking system, set up a system to regulate commercial banks, and enacted other important regulatory and policy innovations. ${ }^{38}$ At the same time, however, the lack of a federal central bank left the states to regulate banking in parallel with the much weaker federal regulatory system. The monetary system changed and largely improved over time, but the progress was halting and sporadic.

The history of this period is, not coincidentally, littered with periodic financial crises (then called "panics"), which bled over from Wall Street to Main Street and became severe economic depressions. Among the worst of these were the Panic of 1873 and the Panic of 1907,39 the latter of which finally moved Congress to create a central bank for the United States, ${ }^{40}$ which came into being in 1913.

Even though the political climate in 1913 finally allowed the creation of a central bank for the United States, Jacksonian distrust of centralized financial power remained a potent force. In particular, the popular appeal of political figures such as William Jennings Bryan was based in large part on the public's fear of Wall Street and worries about the power of banks over people's lives. As a result, the country's new central bank was not called "The Bank of the United States," or "The Central Bank of America." Instead, President Wilson chose the anodyne name "Federal Reserve System." That political sensitivity carried over from the naming of the central bank to the creation of a rather byzantine structure.

37 The National Banking Act, ch. 106, 13 Stat. 99 (1864); The National BankIng Act, ch. 58, 12 Stat. 665 (1863). See also Act of July 13, 1866, 14 Stat. 98, 146-47.

38 The brief histortcal summary in this paragraph and the next two are common knowledge. For a good introduction, see generally JOHNSON, supra note 31 .

39 See 1873: Off the Ralls, HARV. Bus. SCH. (2012) http://www.library. hbs.edu/hc/crises/1873.html [https://perma.cc/SAE5-D99K]; 1907: The Bankers' Panic, HARV. BUS. ScH. (2012) http://www.library.hbs.edu/hc/crises/ 1907.html [https://perma.cc/YC38-VJ3E].

40 See Jon R. Moen \& Ellis W. Tallman, The Panic of 1907, FED. RES. HIST. (Dec. 4, 2015), http://www.federalreservehistory.org/Events/DetailView/97 [https://perma.cc/DE69-M9BK] (noting that the Panic of 1907 spurred the monetary reform movement that led to the establishment of the Federal Reserve System). 


\section{A. Structure of the Fed}

Given the fear of centralizing financial power in New York or Washington, the new Federal Reserve System was created to give the appearance of a nationwide structure, based on what looks like a confederation of twelve regional Federal Reserve banks. ${ }^{41}$ Although they would be part of the federal government, these regional banks were located in important cities across the country, generally reflecting regional population patterns in $1913 .{ }^{42}$

However, had those regional banks been an important part of the policymaking apparatus (or, for that matter, if they had even been helpful in connecting local economies with the central bank), one would have expected to see the creation of more regional federal reserve banks as the economic and demographic centers of gravity in the United States moved westward. Instead, more than a century after its creation, the same twelve Federal Reserve Banks continue to operate, and no new banks have come into existence. It is particularly notable that the only Federal Reserve regional bank in the western half of the United States is in San Francisco, even as regional banks continue to operate in, for example, Richmond, Cleveland, and Kansas City. ${ }^{43}$

The only policymaking power bestowed on regional banks is through their presidents' service as voting members of the Federal Open Market Committee (FOMC). ${ }^{44}$ The voting membership of that committee always includes five presidents of the regional banks, four of whom serve on a one-year rotating basis, with the president of the New York Fed always sitting as a voting member. By contrast, the Board of Governors of the Federal Reserve System consists of seven presidential appoin-

41 The regional banks are located in Boston, New York, Philadelphia, Cleveland, Richmond, Atlanta, Chicago, St. Louis, Minneapolis, Kansas City, Dallas, and San Francisco. The Twelve Federal Reserve Districts, THE FED. RESERVE BD. (Dec. 13, 2015), http://www.federalreserve.gov/otherfrb.htm [https://perma.cc/ 6D7F-XJBJ].

42 HOOVER, supra note 30 , at 625.

43 The regional banks have opened some "branch" banks in major cities such as Miami (a branch of Atlanta's regional Fed) and Los Angeles (a branch of San Francisco's), but those operations are entirely devoted to most mundane tasks. See The Atlanta Fed, FED. RES. BANK OF ATLANTA, https://www.frbatlanta.org/ about/atlantafed.aspx [https://perma.cc/BQY8-WAKV]; Our History, FED. RES. BANK OF S.F. (2016), http://www.frbsf.org/our-district/about/our-history/ [https://perma.cc/3CKN-4TLR]. Certainly, no policy decisions are made even at the regional bank level, much less at the branch level.

44 See G. THOMAS WOODWARD, CONG. RESEARCH SERV., No. 96-672 E, MONEY AND THE FEDERAL RESERVE SYSTEM: MYTH AND REALTTY (1996), http://home.hiwaay.net/ - becraft/FRS-myth.htm [https://perma.cc/TD2N-FXAG]. 
tees, each having a vote on the FOMC and each serving a fourteen-year term. ${ }^{45}$ The President appoints one of those governors as the chairperson of the Fed, for a four-year renewable term, subject to confirmation by the Senate. ${ }^{46}$

The real policymaking power in the Federal Reserve, then, resides in the Board of Governors, which is located in Washington. Although the regional presidents vote on the FOMC, they are, by design, outnumbered by the presidentially appointed governors of the system. Effectively, therefore, the Fed is run as a central bank, from the nation's capital.

\section{B. Powers of the Fed}

Even as the United States was hampered by frequent panics in the pre-Fed period, the country was emerging as a global economic power. Accordingly, the Fed's designers sought to construct an institution with powers commensurate to the nation's role in the global economy. ${ }^{47}$ They bestowed upon it powers that would allow the Fed to intervene when necessary to prevent the financial system from spinning out of control. Financial stability is its central concern.

The Fed is commonly referred to as the "lender of last resort" to signify that the Fed will lend money to key financial players when private sector actors cannot or will not do so, and when the financial system cannot otherwise withstand the disruption that would come from the collapse of a systemically important institution. ${ }^{48}$ The financial system occasionally comes under severe pressure and is in danger of collapse because banks or other financial institutions unexpectedly find themselves short of funds needed to continue operating. For example, if a large bank were to announce an unexpected loss or other worrying news, other banks (in what is known as a "contagion effect") could find that their depositors withdraw more funds from their accounts than they would otherwise wish to withdraw, simply as a matter of caution. This can then create a series of "runs" on banks, all of which need more money on hand than usual to prevent default. None of those institutions would necessarily have engaged in any unwise behavior that would have precipitated the crisis, but all are in

45 Board Members, BD. GOVERNORS FED. RES. SYS., http://www.federalreserve. gov/aboutthefed/bios/board/default.htm [https://perma.cc/8Y2B-WGQL] (last updated Sept. 12, 2014).

4612 U.S.C. \& 241 (2014).

47 See generally JoHNSON, supra note 31 , at 22-32 (describing the political development of the Federal Reserve Act of 1913).

48 CONTI-BROWN, supra note 21, at 151-53. 
danger of collapse because of the interconnected nature of the financial system.

Any such situation poses risks for the real economy as well, because even the most basic operations of a modern business rely on the availability of ready credit. Businesses typically pay their suppliers and employees on a predictable (and legally enforceable) schedule, rather than having to wait until their accounts receivable actually become cash in hand because those businesses have relationships with banks that smooth out cash flows. Moreover, when banks begin to pull back on loans that would have financed other businesses' expansions, or when fewer home mortgages are offered, and so on, the effects cascade onto those whose transactions are contingent on the original loan being completed. (For example, the sellers of House A cannot buy their dream home, House B, unless the buyer of House A receives the loan necessary to close the deal. If that deal falls through, the seller of House $B$ is similarly unable to proceed with her plans to buy House $\mathrm{C}$, and so on.)

These risks are inherent in any financial system because every creditor-debtor relationship is predicated on the ability of the rest of the financial system to provide flows of funds to enable business to be transacted. Therefore, the lender-of-lastresort role of the Federal Reserve is fundamental to its effectiveness as the primary regulator of the U.S. financial system. ${ }^{49}$

Giving the Fed the power to lend money wherever and whenever needed to prevent a crisis, however, necessarily raises two related questions. First, where does the Fed get the money necessary to inject into the financial system when it is needed? And second, if the Fed can put new money into the system at will, might the Fed not run the risk of creating too

49 Notably, the European Central Bank (ECB), which began operating in 1999 in conjunction with the euro, was not formally given the power to act as the lender of last resort for its member countries and banks. European financial crises over the last several years ultimately led the ECB's chairman to declare in 2012 that his institution would do "whatever it takes" to bring stabillty to the Eurozone's financial system. This announcement that the ECB was taking on the lender-oflast-resort role calmed the markets almost immediately. Although many problems remain in Europe, the ECB's decision to act more like the Fed was a major step forward. See generally Gerhard Illing and Phillip König, The European Central Bank as Lender of Last Resort, DIW ECON. BULL., Nov. 2014, at 16, 27-29 https://www.diw.de/documents/publikationen/73/diw_01.c.488640.de/ diw_econ_bull_2014-09-3.pdf [https://perma.cc/B77R-CFET] (describing the possible role of the ECB in future financial crises). 
much money, thus raising the possibility that it would inadvertently set off an inflationary spiral?50

The answer to the first question-where does the money come from?-is counterintuitive but ultimately unavoidable in any economy that is not simply a barter system. Every government, whether or not it nominally ties its currency to a commodity such as gold or silver, and whether or not it creates a central bank, ultimately has the power to create money where money did not exist before. Certainly, every central bank must have that power in order to fulfill its central role as lender of last resort, or else it too would be powerless to break out of the market contagions and other threats that arise in the financial system. When everyone else is pulling back, the central bank must be able to extend itself and do what others cannot or will not do.

As a technical matter, the Fed can create money simply by buying assets from private and government actors, with those actors accepting a check from the Fed. Why does the counterparty accept a check from the Fed? Because it is a check from the Fed, and the Fed is the guarantor of money. Money is, ultimately, an exercise in group psychology. ${ }^{51}$ The Fed thus creates money by "injecting" newly created funds into the financial system, in so doing accumulating assets on its balance sheet, which are matched on the liability side by the Fed's legal requirement to stand behind its money, that is, the dollars that it has created. 52

The second question noted above-if the Fed can create money at will, how can we guarantee that it will not create too much money? - raises the key issue underlying all of modern monetary policy. The answer, however, is generally provided not by having the Fed concern itself directly with the number of dollars that it has created (although it certainly keeps close

50 Although it is beyond the scope of this article, we note here that there is no direct connection between the creation of money and inflation, much less between money growth and hyperinflation. See Paul Krugman, Opinion, Way Off Base, N.Y. TIMES: THE CONSCIENCE OF A LIBERAL (Oct. 7, 2011, 3:15 PM), http://krugman.blogs.nytimes.com/2011/10/07/way-off-base-2/?_r=0 [https://perma.cc/ 9DC7-82E8].

51 See, e.g., Neil H. Buchanan, Money Is Magic, Dorf ON LAW (Feb. 7, 2013, 10:15 AM), http://www.dorfonlaw.org/2013/02/money-is-magic.html [https:// perma.cc/6QTF-LLH8].

52 If someone presents a dollar-a "Federal Reserve Note"-for payment, the Fed is obligated to pay that person in dollars. That is, the obligation to "honor its debts" is simply a requirement that the Fed pay dollars for dollars. It is thus easy to understand why confusion and cynicism about the role of central banks persists. Even though the system can be inherently stable, it is easy to describe it as a shell game. 
track of all such "monetary aggregates"), but with the indirect effect that its asset purchases have on interest rates. That is, when the Fed buys (and sometimes sells) government bonds, it can make the prices of those bonds go up or down. Because the interest rates on bonds are inversely related to the bonds' prices, the Fed can directly target interest rates for government bonds. ${ }^{53}$ For example, if the Fed believes that the interest rate is too low, it can sell bonds, pushing down the price of those bonds and thus pushing up their interest rate. ${ }^{54}$

Although the Fed can also adjust other levers of monetary policy (changing the interest rate on loans that it makes directly to commercial banks, ${ }^{55}$ as well as changing the rules that allow commercial banks to turn deposits into loans), 56 the Fed carries out its monetary policy role almost exclusively through its purchases and sales of government bonds through "open market operations." Those operations allow the Fed to control interest rates, and (as noted above) concomitantly determine how much money the Fed creates.

Together, these mechanisms enable the Fed to create as much money as is necessary to keep the economy healthy, and no more. The Federal Reserve Act requires the Fed to engage in policies to promote "stable prices," which means that if the Fed needs to create money to avert a crisis (through its key role as lender of last resort), it must continually ensure that its preand post-crisis actions recalibrate the setting of interest rates and the creation of money to keep the economy from overheating and thus igniting inflation. ${ }^{57}$

Importantly, however, the Federal Reserve Act requires the Fed (acting through the FOMC) to do more than guard against the possibility that inflation will get out of control. The Fed must "promote effectively the goals of maximum employment,

53 See William J. Baumol \& Alan S. Blinder, Macroeconomics: PRinciples and Policy 249-87 (10th ed. 2006).

54 Although we refer to "the interest rate" as if there were only one such rate, there are many rates, including credit card rates, mortgage rates, corporate bond rates, state and local bond rates, and federal Treasury bond rates. The interest rate that the Fed directly targets is called the Fed Funds Rate, which is the rate on overnight loans between banks. This rate is not directly important for consumer and business transactions, but other rates tend to rise or fall in concert with the Fed Funds Rate. In Part II, we discuss Quantitative Easing, a program in which the Fed sought to move the interest rates on longer-term securities.

55 This is called the discount rate. See BAUMOL \& BLINDER, supra note 53, at 258.

56 The Fed has the power to set "reserve requirements," which determine how much money banks must keep "on reserve" to meet daily cash requirements, rather than lending the money for profit. Id.

57 See 12 U.S.C. \$ $225 a(2014)$. 
stable prices, and moderate long-term interest rates."58 That is, in addition to worrying about inflation (which, again, means worrying about interest rates), the Fed must also attempt to balance concerns about inflation with concerns about unemployment. One sure way to keep prices low, after all, would be to push up interest rates, but that would lead to increases in unemployment. By law, however, the Fed must strike a reasonable balance between inflation and unemployment.

What constitutes such a reasonable balance? Congress spoke to this issue with the Full Employment and Balanced Growth Act of 1978,59 in which it specified that the president should aim for zero percent inflation and three percent unemployment from 1988 onward. ${ }^{60}$ Congress further instructed the Fed to coordinate its monetary policy with the president's policy, thus at least committing the Fed to those goals at one step of remove. In practice, however, those goals have never been met. The unemployment rate briefly dipped below four percent during 2000, but it has never reached three percent, and it has averaged above five percent even in non-recessionary years. ${ }^{61}$ Similarly, the inflation rate has been generally positive (though still quite low) throughout this period. Perhaps more importantly, the Fed several years ago announced a policy goal of two percent inflation-not as a maximum, but as a specific target-based on economic research suggesting that there are needlessly high costs to trying to achieve zero inflation, and that a stable positive inflation target would afford the Fed greater latitude in responding to crises. ${ }^{62}$

$58 I d$.

59 Full Employment and Balanced Growth Act of 1978, Pub L. No. 95-523, 92 Stat. 1887 (codified as amended at 15 U.S.C. $\$ \S 3101-52$ (2014)) (also called the Humphrey-Hawkins Full Employment Act).

60 Rich Karlgaard, The 10\%-10k Conundrum, FORBES (Nov. 12, 2009, 5:22 PM), http://www.forbes.com/sites/digitalrules/2009/11/12/the-10-10k-conun drum/ [https://perma.cc/YF79-3A8S].

61 See Unemployment Rate in the United States from 1990 to 2015, STATISTA, http://www.statista.com/statistics/193290/unemployment-rate-in-the-usasince-1990/ [https://perma.cc/NJW7-WS7Y]. The annual unemployment rate in 2000 was four percent, but for five months of that year it was slightly below that figure. See Labor Force Statistics from the Current Population Survey, U.S. DEP'T LABOR, http://data.bls.gov/timeserles/LNS14000000 [https://perma.cc/Q4Q2VGNY] (set parameters to "2000" to see monthly data).

62 R.A., Why the Fed Targets 2\% Inflation Rate, ECONOMIST: THE ECONOMIST EXPLAINS (Sept. 13, 2015, 11:31 AM), http://www.economist.com/blogs/econo mist-explains/2015/09/economist-explains-7 [https://perma.cc/YRK3-Z9LT]. Recently, the "real" Interest rate has been negative. But because the real rate is the difference between nominal interest rates and the inflation rate, a higher rate of inflation would have allowed the Fed to reduce real interest rates even more than it was able to in a lower-inflation environment. See infra note 110 . 
Even though the specific targets in the 1978 law have not been achieved (and might not even be achievable), the Fed is still required to engage in a balancing act, applying its delegated power to set interest rates and to regulate the financial system to minimize both inflation and unemployment. ${ }^{63}$ Disagreements about the relative weights that the Fed has put on unemployment versus inflation have fueled some of the criticisms of the Fed that we describe in Part II below.

Indeed, some critics of the Fed believe that it should have no policy discretion at all, and that the Fed should instead become nothing more than the employer of a group of technicians who enact a mechanical monetary rule that is set in law by Congress. We next explain why the Fed should not only continue to be given the latitude to adjust policy by applying its reasoned judgment, but that such judgment will be best exercised in an environment where the Fed is largely protected from direct influence by political actors.

\section{Why Is the Fed Independent, and What Does That Entail?}

As we explained in the preceding subpart, the Fed's raison d'etre (based on what might be thought of as its "origin story" in the aftermath of the series of financial panics in the 19th and early 20th centuries) creates a series of related imperatives in the Fed's structure and policy goals. Because the Fed must be able to prevent financial crises, it must be able to provide "liquidity"- that is, to create new money-when the various actors in the financial system simultaneously engage in selfprotecting (and individually rational) actions that could create catastrophic cascading effects. But if the Fed is to be the lender of last resort, it must be mindful that its emergency lending activities can have effects on the money supply and perforce on interest rates. Thus, in order to do its primary job-to prevent financial and economic crises-the Fed must either coordinate with some other (already-extant or hypothetical) agency that is setting money supply and interest rates on a non-emergency basis, or the Fed itself must be given the power to control the money supply and interest rates in both good

63 Even though the Federal Reserve Act specifies "price stabllity" as a goal of the Fed, see What Are the Federal Reserve's Objectives in Conducting Monetary Policy?, BD. GOVERNORS FED. RES. SYS., http://www.federalreserve.gov/faqs/mo ney_12848.htm [https://perma.cc/4C67-QXB9] (last updated June 15, 2016), that does not necessarily require the inflation rate to be zero. Prices can rise at a predictable rate and be "stable" in a meaningful sense. 
times and bad. As a practical matter, even if those roles were separated, the two agencies would need to act effectively as one in order to follow their respective and related policy mandates. And once Congress has given the Fed control over monetary policy in general, it makes sense that the Fed should be required to consider the effects of its policy choices not just on inflation but on unemployment, growth, and other economic policy goals as well.

Having said all of that, however, there is nothing in our account to this point that would require a central bank to be politically independent. That is, the power to create and control the monetary system, which in the United States is an enumerated power of Congress, ${ }^{64}$ could be directly carried out by Congress itself, as part of its ongoing legislative agenda. Just as Congress has not created a politically insulated board to control fiscal policy (taxing and spending), 65 it could decide that it wants to take regular votes on monetary policy issues, setting interest rates directly or indirectly by majority votes in both houses of Congress (subject to the usual Article I, Section 7 rules of presidential vetoes and overrides). Although members of Congress generally possess no expertise in monetary policy, our system of governance does not require expertise, but only democratic representation.

Congress has wisely concluded, however, that its lack of expertise in monetary policy is good reason to delegate its authority to an expert body. Even so, the various duties that the Fed currently carries out, especially the highly essential function of setting interest rates that we described in subpart I.B above, could in principle be delegated to the executive branch. The Treasury Department already bears responsibility for creating physical coins and currency, ${ }^{66}$ and it also carries out various delegated functions of fiscal policy, including borrowing funds to finance federal budget deficits (as we discuss in Part III below). Congress could thus further delegate to Treasury or some other executive branch agency the authority not only to implement aspects of monetary policy but to formulate it as well, so long as Congress complied with the minimal re-

64 U.S. ConsT. art. I, \& 8 ("Congress shall have . . . [the] Power . . . [t]o coin money [and] regulate the (vlalue thereof . . . .").

65 But see Buchanan, Good Deficits, supra note 7, at 126-27 (proposing that Congress create a "fiscal Fed").

66 See Coins and Currency, U.S. DEP'T TREASURY, http://www.treasury.gov/ services/Pages/coins-currency.aspx [https://perma.cc/773R-UR7K]. 
quirement of articulating some "intelligible principle" to guide the agency. ${ }^{67}$

Running monetary policy through either of the political branches, however, would leave open the possibility that the vicissitudes of electoral politics could lead to monetary policy decisions that are keyed to short-term political gains, leading to short-term economic volatility and threatening to undermine longer-term stability and growth. Indeed, the classic argument in favor of a politically insulated monetary authority, as noted in the Introduction, has always been based on the concern that political actors would tend to create too much money, thus risking ever-rising inflation. History is littered with examples of exactly this kind of catastrophe. ${ }^{68}$

As we describe in Parts III and IV, however, this is not the only possible reason to set up the monetary authority as a politically independent agency. Especially in the current political environment, it turns out that the Fed can act as an appropriate counterbalance against political winds that would slow the economy down.

In any event, the current structure of the Fed creates the kind of policy independence that we think is now more important than ever. Although we recognize that independence is a matter of multidimensional degree rather than a simple on/off proposition, ${ }^{69}$ we think it clear that along the most relevant. dimensions, the Fed counts as relatively independent, rather than relatively accountable to the president or to Congress. The terms of the Fed's governors are long (fourteen years) and staggered, so that no single president is likely to be able to

67 E.g., Whitman v. Am. Trucking Ass'ns., 531 U.S. 457, 472 (2001) (quoting J. W. Hampton, Jr., \& Co. v. United States, 276 U.S. 394, 409 (1928)). Such an intelligible principle could look exactly like the current Federal Reserve Act's requirement to strive for maximum employment, price stabllity, and moderate interest rates. "Intelligible" need not mean "specific."

68 The Revolutionary War era spawned the term "not worth a Continental" to refer to worthless currency, reflecting the creation of large amounts of money by the Continental Congress. See The Revolutionary War to the War of 1812, TAX ANALYSTS, http://www.taxhistory.org/www/website.nsf/Web/THM 1777?Open Document [https://perma.cc/G47M-X3QA]. Interwar Germany also famously experienced hyperinflation (and a serious depression) that led to catastrophic political and human consequences. See Mamta Badkar, 10 Hyperinflation Horror Stories of the 20th Century, BUS. INSIDER (Mar. 19, 201 1, 10:09 AM), http:// www.businessinsider.com/10-hyperinflation-stories-of-the-20th-century-2011$3 ? o p=1$ [https://perma.cc/K7ML-M4ZG]. In the 1980s, Argentina experienced extreme hyperinflation that rose to $12,000 \%$ in 1989 . See id.

69 See infra text accompanying notes 172-182. 
reshape the Fed's policy preferences on a wholesale basis. ${ }^{70}$ And even if the president could do so, he would not be able to demand the resignations of Fed governors who subsequently act contrary to the president's immediate preferences.

Similarly, the other voting members of the FOMC are presidents of the regional Federal Reserve Banks. The selection process for regional bank presidents involves even less direct input from the political branches. ${ }^{71}$ Although we agree with critics who suggest that the regional presidents should also be presidentially appointed (and, like the Fed's governors, subject to confirmation by the Senate), ${ }^{72}$ the FOMC under either system possesses the ability to act independently. Voting in an unpopular way cannot result in firing or censure.

Even so, the Fed can still fairly be described as accountable in an important sense. All of the voting members have undergone rigorous public vetting, and all of them have reason to be judicious in making policy choices because they are under intense scrutiny at all times. Moreover, everyone knows that the Federal Reserve exists by act of Congress, and that Congress could at any time change the degree of independence under which the Fed operates, including shutting it down entirely. Reining in the Fed in that way is rightly controversial, and it is understood that efforts to make even modest changes to the Fed (or to the rules governing monetary policy more generally) should be undertaken with great care because of the possible effects of such momentous changes on financial markets and the broader economy. Indeed, we argue throughout this Article that the Fed ought not be made substantially more accountable than it currently is. Even so, the Fed is always on notice that it is not truly free to act only on its own judgment. By contrast with members of the federal judiciary, whose life tenure and salary protection could not be eliminated except by a

70 The possibility of early resignations can create simultaneous appointment opportunities for a president. Even so, a president's ability to change monetary policy through the appointments process is by design much more limited than his ability to control policy made through more directly accountable agencies. See Who Are the Members of the Federal Reserve Board, and How Are They Selected?, BD. GOVERNORS FED. RES., https://www.federalreserve.gov/faqs/about_125 91.htm [https://perma.cc/5GZ5-YgUC] (last updated July 22, 2015).

71 See How Is a Federal Reserve Bank President Selected?, BD. GoverNors FED. RES., https://www.federalreserve.gov/faqs/how-is-a-federal-reserve-bankpresident-selected.htm [https://perma.cc/4P4G-WYK7] (last updated Jan. 25, 2016).

72 See Peter Conti-Brown, Opinion, To Fix the Fed, Simplify It, N.Y. Times (July 29, 2015), http://www.nytimes.com/2015/07/29/opinion/to-fix-the-fed-sim plify-it.html [https://perma.cc/UA8Q-Q76N]. 
constitutional amendment, the Fed's independence could be modified or revoked by ordinary legislation.

In addition, Congress has required that the Fed's chair testify regularly before the relevant committees of the House and Senate, which gives the Fed and Congress the opportunity to engage in (sometimes highly contentious) public exchanges about policy goals.

In these very important senses, therefore, the Fed is politically accountable but policy independent. ${ }^{73}$ This policy independence, however, is currently under attack. Implementing the critics' proposals to undermine Fed independence would harm the Fed's ability to act as a necessary counterweight to other policymakers, especially during a real or potential crisis, as we describe below in Parts III and IV. Before coming to those arguments, in Part II we summarize the proposals of the Fed's critics.

II

CRITICISMS OF THE FED

Proposals to "end" or "audit" the Fed come from critics on both the right and the left. In some respects the various critiques converge, but they also differ on key points. Perhaps more important than sorting conservative from progressive critiques of the Fed is the task of sorting along another axis: between those critiques that, if credited as fair, could be addressed by relatively minor statutory amendments and those that pose a challenge to Fed independence with respect to its fundamental role in making monetary policy decisions, to act as a lender of last resort, and to coordinate its regulatory role with its policymaking role. This Part briefly describes the leading objections with an eye to this latter dichotomy. Because we conclude that some of the criticisms, if credited, really would set the stage for seriously curtailing Fed independence, we turn in the subsequent Parts to underscoring the practical and theoretical grounds for supporting such independence.

\section{A. Statutory Authority}

During and after the 2008 financial crisis, various critics complained that the Fed acted beyond its statutory authority. The most common complaint was that the Fed created dummy entities in order to purchase private assets that it lacked the power to purchase directly. This criticism tends to focus on the

73 See id. 
bailouts of two systemically important financial institutions: Bear Stearns (in the lead-up to the crisis) and AIG (at the height of the crisis). The critics argue that while the Fed has the emergency power to extend credit on favorable terms, ${ }^{74}$ the power of the Fed (and the regional banks in the Federal Reserve System) to purchase assets generally extends only to government-issued instruments, ${ }^{75}$ with such powers as the Fed does have to purchase private assets circumscribed by collateral requirements, time limits, and other constraints. ${ }^{76}$ According to one critic, in creating special-purpose vehicles to bail out Bear Stearns and AIG, "the Fed attempted to use legal trickery to disguise its illegal purchases of private assets from these companies," and thus "acted outside the scope of its statutory authority by effectively purchasing assets that did not fall within the narrow purchase authority provided by the Federal Reserve Act." 77 Other commentators draw similar conclusions. ${ }^{78}$

Are the critics right? Were the Bear Stearns and AIG bailouts illegal? We think the answer is not entirely clear-cut. We agree that the transactions were loans in form but purchases in substance. Yet it does not obviously follow that they were illegal. The law sometimes disregards form in favor of function, but not always. Moreover, at the relevant time, no statutory provision expressly forbade the Fed from using its lending authority to accomplish de facto purchases. The argument for finding in the Federal Reserve Act a tacit prohibition on asset purchases rests on the assumption that if Congress meant to delegate purchase authority to the Fed it would have done so expressly because where Congress did delegate such authority, it came with limits. Silence in this context, goes the argument, is a denial of authority.

Nonetheless, two factors point in the other direction. First, the very idea of emergency lending authority connotes some flexibility. Part of what makes an emergency an emergency is the fact that prior actions did not or could not prepare for the existing circumstances. Thus, one might think that emergency

74 See Federal Reserve Act \$ 13(3), 12 U.S.C. § 343 (2006).

75 See Federal Reserve Act $\S 14(\mathrm{~b}), 12$ U.S.C. $\$ 355$ (2006).

76 See 12 U.S.C. $\$ 344$ (2006) (authorizing secured purchase of bills of exchange backed by certain non-perishable agricultural products, provided the assets are held by the Fed for no longer than ninety days).

77 Emerson, supra note 11 , at 128.

78 See, e.g., Duff, supra note 12, at 202 n.59 (arguing that the Fed circumvented the limits on its purchase authority); Mehra, supra note 12, at 235-36 (arguing that the Fed disguised forbidden purchases as authorized loans). 
authority should be treated as sufficiently elastic to meet the pressing needs of the moment. As Adam Levitin explains, while it is true that the Fed's lending authority was envisioned as authorizing measures to provide liquidity rather than to ensure the solvency of particular firms, during crises (including the last crisis), the line between liquidity and solvency blurs. ${ }^{79}$

Second, as Eric Posner and Adrian Vermeule note, even if the best reading of the statutes would render the Bear Stearns and AIG bailouts unlawful, standard administrative law doctrine grants to agencies the power to adopt a reasonable construction of the statutes they administer, even if that construction is not the construction that a court would give the statutes considering the matter de novo. ${ }^{80}$ They acknowledge that the AIG bailout was "a loan in form" but "a purchase in substance." ${ }^{11}$ Nonetheless, they conclude that "[a] court might find that, in the circumstances, the Fed's implicit interpretation of the statute to permit purchases of distressed nonbank firms in emergency conditions was reasonable." 82

We think it is, at the very least, uncertain whether the Fed's bailouts of Bear Stearns and AIG were legal. However, even if one is persuaded that the Fed acted beyond its statutory authority, and thus illegally, that does not necessarily point to any systemic problem calling for a systemic remedy. The argument that the Fed's actions were legal is at least nonfrivolous, and it should hardly come as a surprise that agencies occasionally assert powers beyond their statutory mandates. When an agency does so, absent judicial intervention, the proper remedy is for Congress to clarify prospectively that the agency either possesses or lacks the relevant power.

Here Congress chose the latter course. Section 1101(a) of the Dodd-Frank Act ${ }^{83}$ amended Section 13 of the Federal Reserve Act to clarify that henceforward any Fed "program or

79 After acknowledging that Section 13 of the Federal Reserve Act was not intended as a bailout mechanism, Levitin explains that "the difficulty that the Fed encountered when dealing with AIG was that liquidity and solvency support bled Into each other." Adam J. Levitin, In Defense of Bailouts, 99 GEo. L.J. 435, 498 (2011). Moreover, quite apart from technical considerations, Levitin cautions that "binding ourselves to eschew [lender-of-last-resort] behavior [by our central bank] would amount to an economic suicide pact." Id. at 499.

80 See Chevron U.S.A., Inc. v. Natural Res. Def. Counc1l, Inc., 467 U.S. 837, 843 n.9 (1984) (announcing the presumption that Congress delegates authority to the agencies it has created to interpret legal questions that cannot be resolved by "traditional tools of statutory"); Posner \& Vermeule, supra note 14, at 1630.

81 Posner \& Vermeule, supra note 14, at 1630.

82 Id.

83 Dodd-Frank Wall Street Reform and Consumer Protection Act, Pub. L. No. 111-203, Title XI, \& 1101(a), 124 Stat. 1376, 2113 (2010). 
facility that is structured to remove assets from the balance sheet of a single and specific company" is ineligible for the sort of emergency lending that the Fed used in combination with the creation of a special purpose vehicle during the financial crisis. ${ }^{84}$

Whether that was the right judgment is also uncertain. If one thinks, as we do, that the Bear Stearns and AIG bailouts were important measures to stabilize the economy, then one would want to clarify that the Fed has the tools to take similar measures in the event of a future crisis. However, viewed ex ante, one might think that by clearly denying the Fed the power to relieve financial firms of their toxic assets, Dodd-Frank removes an incentive for firms to accumulate risky assets that may turn toxic. In this view, Dodd-Frank binds the Fed to the mast when the financial seas are calm, thus signaling to large interconnected firms that the Fed will have no choice but to resist their siren song in the event that their investment strategy threatens to crash the global economy; thus, they will not undertake systemically risky investment strategies in the first place. Similarly, the Fed will have even more reason to be vigilant in monitoring financial developments and preventing crises from developing, lest it find itself faced with another crisis after having been stripped of its best policy response.

We express no view on whether Congress made the right decision by clarifying in Dodd-Frank that the Fed lacks both de jure and de facto authority to purchase troubled financial assets. For our purposes it suffices to note that the questions about the legality of the Fed bailouts of Bear Stearns and AIG do not rise to the level of a structural problem calling for a structural solution such as ending or auditing the Fed.

Nor does Dodd-Frank's clarification of any prior ambiguity in the Federal Reserve Act touch on the central issue of Fed independence. The Fed bailed out Bear Stearns and AIG because no other institution of government was able to do so in a timely fashion, and it had at least a colorable claim of authority. But bailouts need not be a core function of a central bank. True, just as there are reasons of political economy to vest monetary policy in an independent central bank, there are similar reasons to vest bailout authority in a financial actor that is independent of short-term political pressure. In this context too, political accountability can lead to dangerous departures

8412 U.S.C. $\$ 343(3)(B)(i i i)(2012)$. 
from sound economic policy. ${ }^{85}$ And arguably, considerations of expertise suggest that the power to bail out systemically important firms ought to be given to the same independent central bank that already addresses other matters of macroeconomic policy through loans as well as purchases and sales of financial assets.

However, it is also possible to delegate bailout authority to some other independent agency. The Federal Deposit Insurance Corporation (FDIC) has long had resolution authority for a class of depositary institutions, and Title II of Dodd-Frank expanded its role with respect to systemically important financial institutions. ${ }^{86}$ Whether or not the Fed, rather than some other independent agency, has bailout authority simply does not bear on Fed independence with respect to monetary policy. As noted in Part I, separating these functions would necessitate some coordination among agencies that could, at least during a crisis, functionally turn those separate agencies into a single decision-making unit, but that is not necessarily a problem. It would not be our first choice to separate these functions, but separating them would say nothing about the wisdom of maintaining the Fed's ability to act as lender of last resort (because the FDIC would, if the crisis were large enough, run out of money), and to conduct independent monetary policy.

Does this mean that the complaints by critics that the Fed broke the law during the financial crisis can be ignored as irrelevant to our project? Probably, but not necessarily. We acknowledge that a longstanding pattern of law breaking by a government agency would be cause for dramatically reforming,

85 See Duff, supra note 12, at 204 ("The same basic rationale for delegating authority over monetary policy to an independent agency applies to financial stabllity policy."); Levitin, supra note 79, at 505 ("Political accountability . . can also make bailout policy driven by electoral concerns . . . .").

86 See Dodd-Frank Wall Street Reform and Consumer Protection Act, 12 U.S.C. $\S \S 5381-94$ (2012); 12 C.F.R. § 380 (2015); Kwon-Yong Jin, Note, How to Eat an Elephant: Corporate Group Structure of Systemically Important Financial Institutions, Orderly Liquidation Authority, and Single Point of Entry Resolution, 124 YALE L.J. 1746, 1750-51 (2015) (discussing a regulatory gap closed by DoddFrank); Martin J. Gruenberg, Acting Chairman, Fed. Deposit Ins. Corp., Remarks to the Federal Reserve Bank of Chicago Bank Structure Conference (May 10, 2012) (transcript available at https://www.fdic.gov/news/news/speeches/ archives/2012/spmay 1012.html [https://perma.cc/2WZ4-DFBV]) (arguing for broad resolution authority in the FDIC); Martin J. Gruenberg, Chalrman, Fed. Deposit Ins. Corp., Remarks to the Peterson Institute for International Economics: A Progress Report on the Resolution of Systemically Important Financial Institutions (May 12, 2015) (transcript avallable at https://www.fdic.gov/news/ news/speeches/spmay 1215.html [https://perma.cc/546G-EW67]) (explaining the FDIC's role under Dodd-Frank as a supplement to ordinary bankruptcy procedures). 
or even abolishing, that agency. However, in our view, the claim that the Fed exceeded its authority in the Bear Stearns and AIG bailouts, even when fully credited, does not come close to demonstrating a pattern of law breaking. The bailouts, the complaint that they were illegal, and the congressional response in Dodd-Frank were an important episode in and after the financial crisis, but they do not bear on the fundamental question of central bank independence. ${ }^{87}$

\section{B. Transparency}

Critics also charge that the Fed is insufficiently transparent. 88 The validity of this criticism varies with respect to task. The Fed achieves its various objectives through two kinds of actions. In stabllizing the macroeconomy, the Fed buys and sells financial assets, especially Treasury securities. Although situated differently from private actors, in taking such actions, the Fed functions as a kind of market actor. Meanwhile, the Fed also has regulatory authority over various market actors. In carrying out its role as regulator, the Fed operates much like any other agency, promulgating rules and bringing enforcement actions. ${ }^{89}$

In carrying out its regulatory mandates, the Fed ought to be-and is-no less transparent than most other agencies. In

87 We have focused in this subpart on the critics' strongest case, based on the claim that the Bear Stearns and AIG bailouts were outside of the authority of the Fed under Section 13 of the Federal Reserve Act. Some critics argue that in engineering the Bear Stearns bailout the Fed abused its authority to grant exemptions from limits on Fed lending under Section 23A of the Act, 12 U.S.C. \& 371c (2012). Without that exemption, the extension of credit to J.P. Morgan to acquire Bear Stearns would have been clearly unlawful. See, e.g., Orticelli, supra note 18, at 670 (noting that absent the exemption "the statute would expressly prohibit JPMorgan . . . from taking over Bear"). More broadly, on multiple occasions following the collapse of the sub-prime mortgage market, the Fed granted exemptions from Section 23A's limits. "Under the circumstances, the Board's chosen course of action may have been well justified, if not inevitable . . . [but] the crisisdriven exemptions from section 23A, which purposely exposed banks to risks associated with their affiliates' nonbanking business and transferred federal subsidy outside the depository system, were not, and could not have been, consistent with the fundamental purposes of that statute." Omarova, supra note 18, at 1762-63. Although we agree with this assessment, even in combination with the claims regarding violations of Section 13 , it does not lead to the conclusion that the Fed is lawless.

88 See supra note 20; LABONTE, FEDERAL RESERVE: OVERSIGHT AND DISCLOSURE ISSUES, supra note 11 , at 9-10; Emerson, supra note 11 , at 133-37 (pointing to laws that render Fed decision-making relatively opaque to outsiders).

8912 U.S.C. $\S 248$ (2012); Enforcement Actions, BD. GOVERNORS FED. RES. SYs., http://www.federalreserve.gov/apps/enforcementactlons/ [https:// perma.cc/ZU79-BHAR) (last updated Sept. 9, 2014) (listing the entities agalnst which the Fed has authority to take enforcement actions). 
general, modern administrative law strikes a balance between deference to agency expertise and accountability by imposing procedural constraints on agency rulemaking, enforcement actions, and adjudication. More than anything, these constraints aim to expose the reasons for agency decision-making-that is, to render agency action transparent. The Fed falls within the sweeping definition of covered agencies in the Administrative Procedure Act (APA), ${ }^{90}$ and thus, as a regulator, it is legally as transparent as any other agency ${ }^{91}$-and more transparent, at least as a formal matter, than those agencies that are specifically exempt from the APA. With respect to rulemaking, for example, like any other agency covered by the APA, if the Fed wishes its regulations to receive deference in court, it must follow the notice-and-comment procedure affording the public rights to participate. ${ }^{92}$

905 U.S.C. $\$ 551$ (2012).

91 Consider a recent example of accountability via transparency and participation afforded by the APA. "After evaluating thousands of comments" on its proposed rule, the Fed "issued a Final Rule that" differed substantlally from its original proposal. NACS v. Bd. of Governors of the Fed. Reserve Sys., 746 F.3d 474, 481 (D.C. Cir. 2014) (upholding credit card regulation).

92 See Perez v. Mortg. Bankers Ass'n, 135 S. Ct. 1199, 1204 (2015) (noting that mere "interpretative rules" issued outside the notice-and-comment process lack "the force and effect of law and are not accorded that weight in the adjudicatory process") (quoting Shalala v. Guernsey Mem'l Hosp., 514 U.S. 87, 99 (1995)). Courts grant rules promulgated by independent agencies the same degree of deference that they grant to rules that emanate from executive branch agencies. But cf. Andrew T. Bond, Note, Parting the Chevron Sea: An Argument for Chevron's Greater Applicability to Cabinet than Independent Agencles, 90 NOTRE DAME L. REV. 397, 411-17 (2014) (criticizing but acknowledging this feature of administrative law). To be sure, according to some versions of the so-called unitary executive theory, by vesting "The executive Power" in the president, Article II entirely forecloses execution of the law by independent agencies. See, e.g., Steven G. Calabresi \& Kevin H. Rhodes, The Structural Constitution: Unitary Executive, Plural Judiciary, 105 HARV. L. REv. 1153, 1165-68 (1992). However, many of the regulatory activities of the Fed and other independent agencies do not amount to execution of the law. See Humphrey's Ex'r v. United States, 295 U.S. 602, 624 (1935) (distinguishing "quasi-judicial and quasi-legislative" agency action from executive action). Moreover, even with respect to execution, there may be reasons to exempt financial regulation from a putative more general constitutional requirement that law execution be accountable through the president. See Dina Mishra, An Executive-Power Non-Delegation Doctrine for the Private Administration of Federal Law, 68 VAND. L. REV. 1509, 1602 (2015) (explaining that financial regulation "may be" a "context[ ] in which the need for political impartiality is particularly strong," and thus where any requirement of accountability through the president would be appropriately relaxed). Even if the Fed cannot be distinguished from other independent agencles, we treat general arguments about the constitutionality of independent agencies as beyond the scope of this Article. We assume the longstanding status quo permitting Congress to create independent agencies to be constitutional, and focus, chiefly in Part IV, on whether there are sufficient policy justifications for retaining Fed independence. 
Perhaps it could be argued that because the Fed, as an independent agency, is not politically accountable, it ought to be subject to stricter transparency requirements than executive branch agencies. This argument would, in our view, be mistaken. As we shall explain momentarily, ${ }^{93}$ at some point, increased transparency amounts to external control. Yet if it makes sense, all things considered, to grant some regulatory task to an independent agency rather than to an executive branch agency, then it also makes sense to impose no greater transparency requirements on the independent agency; doing so would render the independent agency de facto politically accountable, which would be inconsistent with the initial judgment to make the agency independent.

To be clear, we do not need to quarrel with the claim that some of the regulatory missions now assigned to the Fed might be better assigned to a politically accountable actor, such as the Treasury Department. We take no position on that issue. Our point is only that so long as Congress has good reason to assign a regulatory task to an independent agency like the Fed, Congress also has good reason not to subject the agency to stricter transparency obligations than are thought appropriate for executive agencies engaged in regulation.

For our purposes, the more important question is whether the Fed is insufficiently transparent with respect to monetary policy. As then-Chair of the Fed Ben Bernanke acknowledged in a 2010 speech, the case for transparency of the Fed's market-participant functions is weaker than for the actions the Fed undertakes as a regulator. ${ }^{94}$ But even in the course of championing central bank independence, Bernanke acknowledged that weaker does not mean nonexistent, and Fed monetary policy is in fact somewhat open to public scrutiny. Fed chairs regularly testify before Congress and give speeches, while the FOMC-which sets monetary policy-releases minutes of its meetings and issues reports. ${ }^{95}$ These measures, Bernanke argued, "provide[ ] substantial grist for the activities of legions of

93 See infra text accompanying notes 99-102.

94 See Ben S. Bernanke, Chairman, Bd. of Governors of the Fed. Reserve Sys., Central Bank Independence, Transparency, and Accountability, Speech at the Institute for Monetary and Economic Studies International Conference, Bank of Japan, Tokyo, Japan (May 25, 2010), (transcript avallable at http:// www.federalreserve.gov/newsevents/speech/bernanke20100525a.htm [https:// perma.cc/2DSL-E9FN]) ("[T]he independence afforded central banks for the making of monetary policy should not be presumed to extend without qualification to [their] nonmonetary functions.").

95 see id. 
'Fed watchers' who analyze all aspects of monetary policy in great detail." 96

Bernanke was and is correct that the Fed is not a secret cabal. Still, it can be argued that after-the-fact transparency does little good for those politicians and private actors who disagree with Fed policy. When undertaking notice-and-comment rulemaking pursuant to the APA, the Fed, like other agencies, must give the public an opportunity to comment on its proposed action and then actually give consideration to the public's input before proceeding. ${ }^{97}$ By contrast, although the Fed can fairly be said to tell interested observers what it is doing and why, there are no direct mechanisms for those observers to challenge the Fed's actions. As David Zaring observes, the FOMC is, in practice, "an agency governed by internally developed tradition in lieu of externally imposed constraints." 98

Yet a transparency obligation, even without any mechanism for direct regulation, can act as a form of behavior modification for the actor subject to the obligation. Transparency requirements for private firms ${ }^{99}$ as well as public actors ${ }^{100}$ often work on the principle that sunlight is the best disinfectant. ${ }^{01}$ At the same time, requirements of complete transparency can backfire-as when open meeting laws have the unintended but foreseeable consequence of driving the real action outside of the meeting and thus outside of the spotlight. ${ }^{102}$

\section{Id.}

97 See Motor Vehicle Mfrs. Ass'n. of U.S., Inc. v. State Farm Mut. Auto. Ins. Co., 463 U.S. 29, 54-57 (1983) (rejecting agency's rescission of passive restraint requirement as arbitrary and capricious where it failed to offer adequate basis and explanation for its action).

98 David Zaring, Law and Custom on the Federal Open Market Committee, 78 LAW \& CONTEMP. PROBS. 157, 158 (2015).

99 See Cass R. Sunstein, Informational Regulation and Informational Standing: Akins and Beyond, 147 U. PA. L. REV. 613, 618-29 (1999) (cataloguing and evaluating various regimes of regulation via transparency requirements).

100 The federal Freedom of Information Act and open meeting requirements, 5 U.S.C. $\S 552$ (2012), along with their state analogues, are examples.

101 Louls D. Brandeis, What Publicity Can Do, HARPER's WeEKLY, Dec. 20, 1913, at 10, http://3197d6d 14b5f19f2f440-5e13d29c4c0 16cf96cbbfd 197c579b45.r81. cf1.rackcdn.com/collection/papers/1910/1913_12_20_What_Publicity_Ca.pdf [https://perma.cc/2PV7-VE9P] ("Sunlight is said to be the best of disinfectants ....").

102 See, e.g., 3 United STATES CONSTITUTIONAL CONVENTION, THE RECORDS OF THE FEDERAL CONVENTION OF 1787, at 479 (Max Farrand ed. 1911) (quoting James Madison on the need for privacy during the Constitutional Convention of 1787); James Bowen, Behind Closed Doors: Re-Examining the Tennessee Open Meetings Act and Its Inapplicability to the Tennessee General Assembly, 35 CoLUM. J.L. \& SOC. PROBS. 133, $134(2002)$ (promoting "a zone of privacy in which . . . discussions can freely take place [because s]unshine laws present the real possibility of 
Most deliberative bodies need at least some opportunities to meet in private so that members can speak freely. Even absent any illicit motives, both private and public actors will hesitate to give voice to positions that they wish to explore tentatively for fear that the public or a subset thereof will overreact. Where the relevant actors are the policy makers of a central bank-and with global markets finely attuned to interest rates-the risk is acute.

There are also questions of practicality. Each day the Fed (or more precisely, the Federal Reserve Bank of New York, acting on behalf of the FOMC) purchases and sells financial assets in order to carry out monetary policy. ${ }^{103}$ These numerous transactions could not possibly achieve their aim in real time if they were subject to the sort of back and forth with the public associated with notice-and-comment rulemaking.

Accordingly, during a July 2015 appearance before the House Financial Services Committee, Fed Chair Janet Yellen resisted calls for greater direct oversight of the Fed, treating proposed transparency requirements as a form of congressional control. ${ }^{104}$ One need not agree with Yellen that current law requires exactly the right degree of Fed transparency to see two general truths: first, that for just about any entity, there is an optimal level of transparency that falls short of total transparency; and second, that given the tendency of transparency to bleed into external control, where policy factors justify making an agency independent of direct external political control, the optimal level of transparency for that agency will be some-

deleterious incidental effects.") (footnote omitted); TIm Groseclose \& Nolan McCarty, The Politics of Blame: Bargaining Before an Audience, 45 AM. J. POL. SCI. 100,114 (2001) (finding a chilling effect of sunshine laws); Rebecca M. Kysar, Listening to Congress: Earmark Rules and Statutory Interpretation, 94 CORNELL L. REV. 519, 531 (2009) ("[T]ransparency may promote polarization and partisanship in the political dialogue.") (footnote omitted).

103 FED. RESERVE BANK OF RICHMOND, THE FEDERAL RESERVE TODAY 12 (16th ed. 2012), https://www.richmondfed.org/ /media/richmondfedorg/publications/ education/federal_reserve_today/frtoday.pdf [https://perma.cc/47XC-JWP7] (describing how the Open Market Committee conducts monetary policy); Open Market Operations, FED. RES. BANK N.Y., http://www.newyorkfed.org/aboutthefed/fedpoint/fed32.html [https://perma.cc/4FWY-N7XB] (explaining the role of the New York Fed); What We Do, FED. RES. BANK N.Y., http://www.newyorkfed. org/aboutthefed/whatwedo.html [https://perma.cc/7YLY-X5CE] (same).

104 See Binyamin Appelbaum, Janet Yellen Warns Congress Against Adding to Fed's Oversight, N.Y. TıMEs (Jul. 15, 2015), http://www.nytimes.com/2015/07/ 16/business/yellen-federal-reserve-house-testimony-oversight.html [https:// perma.cc/DUX5-LUNA] (quoting Fed Chair Yellen stating that "[e]fforts to further increase transparency, no matter how well intentioned, must avoid unintended consequences that could undermine the Federal Reserve's ability to make policy in the long-run best interest of American families and businesses"). 
what less (other things being equal) than the optimal level of transparency for agencies deemed properly subject to such control. ${ }^{105}$

Thus, the claim that the Fed is insufficiently transparent has two dimensions. To the extent that the critics wish to see the Fed subject to greater transparency requirements in its regulatory functions, they may or may not have a point, but even if they do, greater transparency in this domain would not undermine the Fed's core functions when it acts as a central bank. This aspect of the claim touches nothing fundamental. However, to the extent that the critics would like to see greater transparency in the Fed's conduct of monetary policy as a means of controlling such policy, the prescription would undermine Fed independence in an area where such independence has been thought essential to its role as a central bank.

\section{Substantive Priorities}

The Fed's substantive mandate obligates it to set and carry out monetary policy in such a manner that will "maintain long run growth of the monetary and credit aggregates commensurate with the economy's long run potential to increase production, so as to promote effectively the goals of maximum employment, stable prices, and moderate long-term interest rates." 106 As we noted briefly in Part I, these objectives can conflict. Other things being equal, and when the economy lacks substantial excess capacity, lower interest rates boost employment but also increase the risk of inflation, and viceversa. Accordingly, actors with different interests will sometimes criticize the Fed for unduly emphasizing one aspect of its mandate at the expense of another. To paint with a very broad brush, conservatives would like the Fed to focus chiefly on fighting inflation, while progressives would like to see the Fed promote economic growth and thus job growth. ${ }^{107}$

105 These are general rather than universal truths. Consider military affairs. Article II enshrines civilian control of the military by making the president Commander in Chief. The armed forces thus are not an independent agency. However, the need for operational secrecy will often be inconsistent with transparency to the general public or even to all of Congress.

10612 U.S.C. § 225a (2012).

107 See, e.g., Michelle A.L. Goldberg, Note, The Fed's Dual Mandate: One Too Many?, 33 REV. BANKING \& FIN. L. 343, 352 (2013) (detailing Democratic support for and Republican opposition to the Humphrey-Hawkins Full Employment Act, which made explicit the unemployment prong of the Fed's dual mandate); Mark Felsenthal, Fed Officials Not Attached to Dual Mandate, REUTERs (Jan. 9, 2011, 5:38 PM), http://www.reuters.com/article/2011/01/09/us-usa-fed-mandate-id USTRE70839720110109 [https://perma.cc/RWZ6-ULS6] (quoting Mike Pence, 
It is tempting to say that if the Fed is simultaneously being criticized from the right for being too soft on inflation while being criticized from the left for being too soft on unemployment, then it must be doing its job just right by steering a middle course, consistent with its multi-factor mandate. But that is not necessarily correct. Although economists disagree about the relative contribution of the price shock in oil and monetary policy in causing stagflation in the $1970 \mathrm{~s}, 108$ there is little doubt that a poorly run central bank (in combination with external public and private factors) can set and conduct monetary policy in a way that neither constrains inflation nor promotes job growth. The very possibility of stagflation shows that monetary policy is not necessarily a zero-sum game, with every action that exacerbates one problem necessarily contributing to a solution to the converse problem.

The post-2008 crisis period provides another, more positive example of how inflation and unemployment are not strictly inversely correlated. Despite repeated dire warnings by conservatives that extremely low interest rates would lead to

then the No. 3 House Republican (and currently Governor of Indiana and Republican Vice Presidential nominee), saying that the Fed "could do more for the American economy by focusing singularly on maintaining the value of the dollar and protecting the purchasing power of Americans .... .); see also id. ("[W]ith the Democrats in control of the White House and the Senate, a move to strip the Fed's employment mandate would be unlikely to gain sufficient backing to become law."); Arjun Kapur, Janet Yellen and the Future of the Federal Reserve, HARV. POL. REV. (Dec. 31, 2013, 12:49 AM), http://harvardpolitics.com/united-states/janetyellen-future-federal-reserve/ [https://perma.cc/D3SC-BN2V] ("One might expect Republicans to run a tight monetary policy and Democrats an easy one ....").

108 See Alan S. Blinder \& Jeremy B. Rudd, The Supply Shock Explanation of the Great Stagflation Revisited 46 (Princeton Ctr. for Econ. Policy Studies, Working Paper No. 176) (2008), https://www.princeton.edu/ceps/workingpapers/ 176 blinder.pdf [https://perma.cc/8AR4-TSMV] (concluding that supply shocks were chiefly responsible for unemployment during stagflation-60\% and $45 \%$ in the 1970 s and 1980-82, respectively-with monetary policy playing only a minor role). But see Robert B. Barsky \& Lutz Killian, Do We Really Know that Oil Caused the Great Stagflation? A Monetary Alternative, 16 NBER MACROECONOMics ANNUAL 137, 163-70 (2002), http://www.nber.org/chapters/c11065.pdf [https:// perma.cc/3NJY-KZU2] (arguing that exogenous oil supply shocks alone were insufficient to cause stagflation in the 1970s); see also Robert B. Barsky \& Lutz Kilian, Oil and the Macroeconomy Since the 1970s, 18 J. ECON. PERSP. 115, 133 (2004) https://fraser.stlouisfed.org/docs/meltzer/jep_2004_barsky_lutz_oil macro.pdf [https://perma.cc/L8YE-P8BH] (“[O]il price shocks are neither necessary nor sufficient to explain stagflation in real GDP and in the implicit GDP deflator."); Lutz Kilian, Oil Price Shocks, Monetary Policy, and Stagflation 64-70, (Ctr. for Econ. Policy Research, Discussion Paper No. DP7324, 2009), http:// www-personal.umich.edu/ lkilian/rbakilianpub.pdf [https://perma.cc/W5Y8GTRQ] (suggesting that exogenous oil price shocks led to stagflation because the Fed raised interest rates in response to the resulting inflationary pressures). 
runaway inflation, ${ }^{109}$ the Fed's policy-including effectively negative interest rates for some of the recent period ${ }^{110}$-has not led to high inflation, even though that policy has been in place for almost eight years.

Meanwhile, some of the policy preferences expressed by some conservatives are, to put the point politely, not exactly reality-based. The charge that the Fed has debased the currency ${ }^{11}$ could most charitably be understood as a shorthand for the mistaken but not completely irrational fear that increases in the money supply would lead to inflation. This view is mistaken because the link between low interest rates and inflation depends on the economy functioning at or close to full capacity. ${ }^{112}$ However, the fear is not irrational because timing is delicate. It is at least possible that a central banker could

109 See, e.g., Merrill Goozner, Bernanke Defends Low Interest Rates as Necessary, FISCAL TIMES (Feb. 2, 2012), http://www.thefiscaltimes.com/Articles/2012/ 02/02/Bernanke-Defends-Low-Interest-Rates-As-Necessary [https://perma.cc/ GM2Y-6M2P] (citing Republican Congressman Paul Ryan's warning that low interest rates would lead to higher inflation); Victoria McGrane, GOP Senate Takeover Puts Fed on Hot Seat, WALL ST. J. (Nov. 5, 2014, 12:11 AM), http://www.wsj. com/articles/gop-senate-takeover-would-put-fed-under-microscope-141510 4673 [https://perma.cc/SX7S-YLTS] (explaining that Alabama Senator Richard Shelby voted against Janet Yellen due to her support for bond-buying programs, which he believed would lead to inflation); Cliff Asnes et. al., Open Letter to Ben Bernanke, WALL ST. J. (Nov. 15, 2010, 12:01 AM), http://blogs.wsj.com/econom ics/2010/11/15/open-letter-to-ben-bernanke/ [https://perma.cc/VLAB-EHST] (warning that quantitative easing would result in inflation).

110 Richard G. Anderson \& Yang Liu, How Low Can You Go? Negative Interest Rates and Investors' Flight to Safety, REGIONAL ECON.: FED. RES. BANK ST. LOUIS, Jan. 2013, https://www.stloulsfed.org/ /media/Files/PDFs/publications/pub_ assets/pdf/re/2013/a/investments.pdf [https://perma.cc/A7FS-2LJY] (calculating real interest rates as negative); Diana A. Cooke \& William T. Gavin, The Ups and Downs of Inflation and the Role of Fed Credibility, REGIONAL ECON.: FED. RES. BANK ST. LoUIS, Apr. 2014, https://www.stlouisfed.org/ /media/Files/PDFs/ publications/pub_assets/pdf/re/2014/b/credibility.pdf [https://perma.cc/ 5GG5-9JZH] (same).

111 See, e.g., Lerer \& Hirschfeld Davis, supra note 11 (quoting then vice presidential candidate Paul Ryan saying "[t]here is nothing more insidious that a government can do to its countrymen than to debase its currency-yet this is in fact what is occurring"): Paul Krugman, Opinion, Money Makes Crazy. N.Y. TIMES (Feb. 13, 2015), http://www.nytimes.com/2015/02/13/opinion/paul-krugmanmoney-makes-crazy.html?_r=1 [https://perma.cc/D8TX-CM69] ("Mr. Paul likes to warn that the Fed's efforts to bolster the economy may lead to hyperinflation; he loves talking about the wheelbarrows of cash that people carted around in Weimar Germany.").

112 See, e.g., Paul Krugman, Check Out Our Low, Low (Natural) Rates, N.Y. TIMES: THE CONSCIENCE OF A LIBERAL (Oct. 28, 2015, 10:34 AM), http://krugman. blogs.nytimes.com/2015/10/28/check-out-our-low-low-natural-rates/ [https:// perma.cc/WAV4-Z5GS] (noting, in the sixth year after the recession officially ended, that "we've had multiple years of very low rates, with no hint of a runaway boom or an inflationary takeoff"). 
keep interest rates too low too long out of the erroneous belief that the economy has more excess capacity than it in fact has.

Yet some Fed critics pretty clearly do not simply mean their objections as shorthand for a view about the timing of interest rate increases. Rather, in the period since the crisis, some commentators have issued the debasement charge based on the apparent belief that increasing the money supply is inherently problematic. For example, the complaint that that the Fed's policy of quantitative easing created money "out of thin air" 113 assumes as a baseline some definition of money that is not created out of thin air. Yet that assumption is unwarranted. Any medium of exchange-including precious metalhas value only because people believe that other people will continue to believe that it has value. There are sound reasons why, in particular circumstances, the money supply ought not to be increased, but the mere fact that a central bank in a sovereign nation with its own currency can increase the money supply without having to discover and dig up nuggets of a material that is arbitrarily denominated as valuable is not itself a ground for concern. ${ }^{114}$

Likewise, calls by some on the right to amend the Fed's mandate so that it only focuses on inflation ${ }^{115}$ cannot be taken at face value. A central bank that viewed its mission as solely and constantly battling inflation would risk sending the econ-

113 See supra note 13.

114 Moreover, even those countries that wish to tie their currency to such nuggets of a precious metal must still set policies that determine how much currency is supported by a given weight of the metal. Setting that amount is monetary policy. The only question is who should set that policy. Our argument is not that we must choose between a system with a human element and one that is purely mechanical. Instead, we must choose between systems on the basis of which humans, in which institutional arrangements, will make those policy decisions. See infra text accompanying notes 120-122.

115 See LABONTE, CHANGING THE FEDERAL RESERVE's MANDATE, supra note 15, at Summary (describing bills that "would strike the goal of maximum employment from the mandate, leaving a single goal of price stability, and require the Fed to adopt an inflation target"); Goldberg, supra note 107, at 368 (citing Daniel Thornton of the Federal Reserve Bank of St. Louis for the proposition that most economists do not support the dual mandate because they believe elther that unemployment is affected by economic fundamentals distinct from monetary police or price stability alone check unemployment); Victorla McGrane \& Kristina Peterson, For Yellen, Fed's Dual Mandate Guides Thinking, WALL ST. J. (Nov. 12, 2013, 7:31 PM), http://www.wsj.com/articles/SB100014240527023048684045 79194300406860572 [https://perma.cc/ADU7-T8KB] ("[S]ome Republicans think the employment component has taken the Fed's focus off the more important and achievable mission of low inflation."); Timothy Lavin, End the Fed's Dual Mandate and Focus on Prices, BLOOMBERGVIEW (Sept. 16, 201 1, 2:27 PM), http:// www.bloombergview.com/articles/2011-09-16/end-the-fed-s-dual-mandateand-focus-on-prices-john-b-taylor [https://perma.cc/5H6R-KUAS]. 
omy into a deflationary spiral that could easily turn into a depression. No one could sensibly advocate that the Fed target a zero rate of inflation because even a small error on the wrong side could yield deflation. Accordingly, the rational version of the conservative critique of the Fed's multi-prong mandate must be that the critics wish to see the balance struck differently. So long as there is no serious risk of deflation, the critics mean (or at least ought) to say that the Fed ought not permit additional inflation as the price of promoting job growth.

That claim finds its mirror in a criticism by progressives that, notwithstanding its multi-prong mandate, too often the Fed has prioritized fighting inflation over promoting economic and job growth. ${ }^{116}$ This critique sometimes has an institutional component. The Fed is a hybrid public/private entity that gives substantially greater weight to the interests and outlook of bankers and investors than to the interests of Americans who live from paycheck to paycheck. Accordingly, the argument goes, the Fed is rigged to favor its inflation-fighting mandate at the expense of job growth. ${ }^{117}$

This charge strikes us as simplistic and unrealistic. It is certainly true that workers (for example) are not directly represented in the Fed's monetary-policy-making processes. But it does not follow that their interests are unrepresented, partly because economic progressives are not the only people who (other things being equal) prefer low interest rates. Investors in

116 See LABONTE, ChANGing THE FEDERAL RESERve's MANDATE, supra note 15, at 4 ("It is debatable whether an inflation target is compatible with the equal weighting of maximum employment and price stability in the dual mandate-arguably, it communicates to the public a greater focus on inflation . . . ."); George A. Kahn \& Lisa Taylor, Evolving Market Perceptions of Federal Reserve Policy Objectives, FED. RES. BANK KAN. CITY ECON. REV., First Quarter 2014, at 5, https://www.kansascity fed.org/publicat/econrev/pdf/14q1Kahn-Taylor.pdf [https://perma.cc/M9H69FSW] ("[D]uring the Volcker era when inflation was deemed excessive, policymakers placed a high priority on lowering inflation even at the expense of high and rising unemployment. During the Greenspan era, as further disinflation was achieved, policymakers emphasized 'sustainable economic growth,' with a view that such an outcome could be achieved only in an environment of low and stable inflation."); Thornton, supra note 15, at 128 (noting that former Fed Chairman Paul Volcker made a case for "inflation first" monetary policy); Cameron DeHart, The Federal Reserve's Dual Mandate: Balancing Act or Inflation Fixation? 5 (Apr. 16,2013 ) (unpublished honors research thesis, The Ohio State University) (on file with The Ohio State University Knowledge Bank), , https://kb.osu.edu/dspace/ bitstream/handle/181 1/63984/DeHart_Honors_Thesis.pdf?sequence $=1$ [https:/ /perma.cc/VWS4-NJX4] ("The Fed uses its independence to re-interpret the dual mandate' such that price stability is a precondition for maximum employment.") (emphasis omitted); id. at 11 (" $[$ A]nalytical evidence suggests that the Fed was decidedly more focused on inflation during the observed time period."); see also Bd. of Governors of the Fed. Reserve Sys., supra note 15.

117 See supra notes 14-15. 
stocks and holders of existing bonds like low interest rates as well. ${ }^{118}$ Thus, insofar as the Fed's structure gives weight to the preferences of investors, that does not systematically disfavor pro-growth policies. And indeed, the Fed's record since the crisis (and, somewhat less consistently, before the crisis as well) shows that whatever else one might say about the Fed, it has hardly been captured by inflation hawks.

To be clear, we do not claim that the Fed is a "Goldilocks" agency, always setting monetary policy neither too much in one or the other direction but always "just right." We are keenly aware that when inflation and growth correlate inversely, as they often do, it is possible for the Fed to err in one way or the other. Whether one thinks that the Fed has erred, or over time likely will err, in either direction will depend on one's interests and outlook. Our concern here is how judgments about the Fed's priorities might translate into concrete reforms.

In principle, it should be possible to set different priorities for the Fed without challenging Fed independence. For example, the Fed's statutory mandate could be rewritten to specify a numerical target of, say, two percent annual inflation, or three percent unemployment, or some particular formula that incorporated both-for example, minimize unemployment unless further steps to promote employment would cause inflation to rise above two percent.

In practice, however, the diversity of economic circumstances that can arise will mean that a rigid numerical formula will likely lead to a policy path that even a proponent of the formula would regard as suboptimal. For example, even holding inflation constant, there will be disagreement about the socalled natural rate of unemployment, and a statutory mandate based on assumptions that prove false over time could lead to a Fed that is bound by that mandate to adopt harmful monetary policies. In a macroeconomy that can fairly be described as subject to the influence of "animal spirits," 119 any rule-like approach to a central bank's mandate will leave the central bank with insufficient flexibility to rein in those spirits.

The solution-embodied in the Fed's existing multi-factor mandate-is to delegate to the central bank the discretion to

118 ANDREw B. ABEL, Ben S. Bernanke, \& DEAn Croushore, Macroeconomics 141 (6th ed. 2008) ("[A] higher real interest rate increases the user cost of capital and thus reduces desired investment."); N. GREGORY MANKIW, MACROECONOMICS 421 (6th ed. 2007) (stating that higher interest rates lead to decreases in investment). 119 JOHN MAYNARD KeyNES, THE GENERAL THEORY OF EMPLOYMENT, INTEREST AND MONEY 161 (1936). 
make an all-things-considered judgment about how to balance the sometimes-conflicting goals of monetary policy. This solution should be very familiar to anyone acquainted with the modern administrative state. Given the complexity and fluidity of the problem, a generalist legislature cannot formulate sensible precise rules in advance and so sets the broad outlines of the policy, leaving to the agency the task of filling in the details.

Accordingly, whether one thinks that the Fed tends to favor too-loose or too-strict monetary policy, one cannot sensibly propose ex ante formulaic controls on the Fed. This may explain why, regardless of where they fall on the political spectrum, many critics of the balance the Fed has struck among the factors in its multi-factor mandate seek to subject the Fed to ongoing political oversight. They cannot settle for a one-time change in the Fed's mandate substituting a rigid rule for Fed discretion because such discretion is needed to give sensible effect to any set of priorities. Instead, these critics aim to rein in the Fed each time it uses its discretion in ways the critics dislike. The critics want political actors to be able to require the Fed to make course adjustments that the Fed, in its discretion, would not otherwise make. In short, although not on its face a challenge to Fed independence, the claim that the Fed pursues the wrong priorities amounts in practice to a challenge to such independence.

There are also those who criticize the Fed for failing to adopt a rule-based monetary policy regime. In monetary theory, this is known as the "rules versus discretion" debate. ${ }^{120}$ One type of rule would tie the value of money to the supply of a commodity or set of commodities, the most famous version of which is the gold standard. But other rules are possible as well. For example, some economists have long called on the Fed to increase the money supply by a fixed percentage each year, with the rate determined by a simple equation. ${ }^{121}$ The

120 See, e.g., William Van Lear, A Review of the Rules Versus Discretion Debate in Monetary Policy, 26 E. ECON. J. 29, 29-39 (2000) (providing an overview of the debate).

121 The "quantity equation," usually written $M V=P Q$, when converted to annual rates of growth, connects the desired growth rate of the money supply $(M)$ to the growth in the rate at which money is used in transactions (the "velocity" of money, $V)$, the rate of growth of the price level $(P)$, and the rate of growth of real GDP $(Q)$. See Equation of Exchange $(M V=P Q) /$ Quantity Theory of Money, EcoNMENTOR, http://www.econmentor.com/college-macro/associated-macroeconom ic-topics/money/equation-of-exchange-mv=PQ - quantity-theory-of-money/text/ 362.html [https://perma.cc/ECM2-TTXE]. The last three variables are assumed to grow at constant rates, making it possible simply to mandate that the Fed increase $M$ at the rate necessary to achieve stable prices and economic growth. 
idea is to prevent the Fed from exercising discretion in setting monetary policy because the consequences of the Fed's overreacting or underreacting are supposedly worse than not acting at all.

There would thus appear to be two separate questions here. First, should monetary policy be operated under a fixed set of mechanical rules, or instead should the conduct of monetary policy be deliberately arranged to require ongoing human judgment in responding to emerging evidence? Second, if human judgment is going to be part of the setting of monetary policy, should that human judgment be exercised by politically insulated human beings or by more directly politically accountable human beings?

In one sense, then, our enterprise in this Article would seem to require us simply to assume that the answer to the first question is "discretion, not rules," and then to answer the second question by saying that such discretion should be exercised by an independent Fed. Yet that is not in fact our approach. We argue that the first question presents a false choice. Even if one thinks that monetary policy should be carried out according to rigid rules, there must be a human element in determining the content of those rules in the first place, including rules about whether and how the rules can be changed. Those rules can be set legislatively (that is, by politicians directly), by executive agencies (whose personnel are appointed and removable by politicians), or by an independent agency (whose staff are sheltered from direct political control). Our argument, that politically independent economic specialists should set monetary policy, thus subsumes the "rules versus discretion" question because we recognize that that debate-although important on its own terms, as a matter of determining the Fed's actions on an ongoing basis-falsely imagines that human judgment can be removed from the establishment and maintenance over time of a monetary system.

For example, if Congress decided (quite unwisely, in our view) to put the U.S. back on a gold standard, it might also decide that the only way to change the dollars-to-gold ratio in the future would be by enacting new legislation; in other words, the gold-standard legislation itself would set the ratio. Or, Congress could decide (much more wisely, at least given its

See id. This theory has long been contested, and the empirical evidence shows that the relevant variables change over time at varying and unpredictable rates. See IRVING FISHER, THE PURCHASING POWER OF MONEY: ITS DETERMINATION AND RELATION TO CREDIT, INTEREST AND CRISES 149-84 (1911). 
initial bad decision to adopt a gold standard) to set rules that anticipate when and by whom the ratio could be altered or even that the gold standard could be abandoned entirely, for example, during a crisis like 2008. Our argument here is that, no matter what the background regime might be, there is virtually no rules-based regime that removes the human ability (and responsibility) to set the rules and to alter the rules. ${ }^{122}$ The best institutional design, in our view, would have politically independent human beings making judgments about when and how to change the rules.

We have seen in this Part that some of the criticisms that have recently been leveled at the Fed do not challenge the Fed's independence in the area where conventional wisdom holds that it needs to be independent of day-to-day political influence: in the making and implementation of monetary policy. Yet some such criticisms do pose a challenge in just that area. We think that many of these criticisms are mistaken as a substantive policy matter, but others will draw different conclusions. If one is persuaded that Fed independence stands as an obstacle to substantively optimal policy, one will need a very strong reason for valuing Fed independence more highly than the substantive policy. Thus, we turn next to asking whether there is a strong justification for Fed independence.

III How the FED SAVEd THE ECONOMY, AND WHY IT Might
HAVE TO DO SO AGAIN

The Federal Reserve's role as an independent central bank necessarily puts it in a unique position in the U.S. economic and political system. When a crisis emerges, the Fed's combination of expertise and political insulation gives it the ability to respond quickly and with appropriately calibrated strength to prevent matters from getting truly out of hand, and to guide the financial markets and the economy back toward stability. The

122 The only exception that occurs to us would be an unamendable constitutional provision setting forth a mechanical rule. Although the initial adoption of such a rule would require the exercise of judgment, its subsequent operation would be, in principle at least, automatic. We dismiss this possibility because even those constitutions that purport to permanently entrench certain features, such as Article 79(3) of the German Basic Law, do not entrench institutional arrangements regarding monetary policy. See GRUNDGESETZ [GG] [BASIC LAW], art. 79(3), translation at https://www.gesetze-im-internet.de/englisch_gg/englisch _gg.html [https://perma.cc/LB6P-YY97]. 
Fed's recent performance in preventing a complete global economic meltdown is one of the under-appreciated stories of our time.

Moreover, the Fed's necessary emergency actions might be needed again in the not-too-distant future, in a situation that would make it clear that the Fed's vaunted independence is essential to solving and preventing self-inflicted damage. Perversely, however, if the Fed's actions actually do frustrate the desires of the politicians who might precipitate such a crisis, the Fed could be required to sign its own political death warrant in order to rescue the economy. Fortunately, there is a way to save the Fed from having to make such a fateful choice, as we discuss below.

\section{A. The Fed, the Existential Crisis of 2008-09, and the Aftermath}

Like most institutions of government, the Federal Reserve is designed to operate normally during normal times. ${ }^{123}$ Its day-to-day activities certainly include vigilantly scanning the horizon for storms, but most of its resources are quite sensibly devoted to making sure that the financial system runs smoothly even when no crises are imminent. Because some serious problems can arise not only from unexpected outside forces (such as a spike in a vital commodity such as oil due to a war in the Middle East, or a stock market crisis in a major foreign trading partner like China) but also from imbalances within the U.S. financial system, the Fed must actively ensure that the financial system is not developing problems that could suddenly metastasize into full-blown crises. Its regulatory role, therefore, is in part designed to guarantee that normal day-today operations are held within safe boundaries.

As we noted in our Introduction, ${ }^{124}$ one might reasonably fault the Fed for failing to carry out its oversight duties of the financial system during the years leading up to the 2008 global financial crisis. Especially in a low-interest rate environmentwhich was a sensible policy posture during that time period, given the continued weakness of the economy throughout George W. Bush's presidency - the Fed, at least with the benefit of $20 / 20$ hindsight, should have been much more vigilant

123 Some agencies are designed specifically to deal with unpredictable crises, such as the Federal Emergency Management Agency. 6 U.S.C. § 313 (2012). Even those agencies have ongoing operations and management imperatives that they pursue between crises.

124 See supra text accompanying note 18. 
about the emergence of problems that were perhaps inevitable in an economy where housing prices were rising very rapidly.

As we described in Part $I$, the fundamental danger in any financial system is that the banks could experience flash crises known as "runs," which can destroy not just individual banks but, through financial contagion effects, also spread to otherwise healthy financial institutions. ${ }^{125}$ Although the Fed, in its early years, failed its first big test of being the "lender of last resort" at the onset of the Great Depression in 1929 (and continuing for years thereafter), the Fed learned its lesson and subsequently became the lynchpin of a system that has protected the U.S. financial system from further such crises. ${ }^{126}$ The period between the end of the Great Depression and 2008 was not, obviously, one of uninterrupted prosperity, ${ }^{127}$ but it was a period notable for a significant decrease in the frequency and severity of financial and economic crises, compared to the decades before the Great Depression.

With hindsight, we now know that the 2000s boom in housing was enabled by the emergence of a so-called "shadow

125 For a particularly vivid depiction of a bank run, see IT'S A WONDERFUL LIFE (Liberty Films (II) 1946). There, the depositors in a financial institution learn that there is insufficient cash on hand for the institution to pay daily withdrawals. At that point, all of the depositors demand to be refunded their money immediately, which of course is not possible. A short-term cash flow problem thus threatens to shutter a fundamentally healthy financial institution. The film does not depict the effect that this run would have on other institutions, when word spread that depositors at this particular institution had not been pald their money. This fictionalized account repeatedly played out in real life, to disastrous effect, through the early years of the Great Depression.

126 Congress played a role as well, instituting important protections such as deposit insurance, along with other securities regulation and similar innovations. See 12 U.S.C. $\S 1811$ (2012). Congress repealed one of the most important protections against systemic collapse-the formal separation of commercial banks and investment banks-several decades later. Arguably, this later change and other deregulatory actions by Congress and relevant agencies set the stage for the 2008 crisis. The Glass-Steagall Act of 1933 (Banking Act of 1933), ch. 89, $\$ \$ 16$, $20,21,32,48$ Stat. 162 (1933) (codiffed as amended in scattered sections of 12 U.S.C.), repealed in part by The Gramm-Leach-Bliley Act of 1999, Pub. L. No. 106102, 113 Stat. 1338 (1999). Therefore, although we partly fault the Fed for failing to prevent the buildup of the financial imbalances that led to that crisis, we recognize that the Fed was perhaps only at fault for falling to respond adequately to a disaster that was set in motion by the unwise decisions of political actors.

127 This long period of rising national income has, unfortunately, also been a period of rising inequality. Although distributive justice is generally not within the Fed's policy goals, critics on the political left have long faulted the Fed for engaging in policies that enrich financial market players while paying insufficient attention to monetary policy's effects on the middle class and poor. See supra text accompanying notes 116-117. 
banking" sector. ${ }^{128}$ That is, although the Fed and other relevant regulators were able to prevent the banks from experiencing the types of runs that nearly destroyed the economy in the 1930s, investment banks like Lehman Brothers and a growing number of hedge funds were engaging in bank-like activities that created a global market in payment streams from aggregated mortgage debt, which in turn led to irresponsible lending. Whereas in the earlier period, a conventional local mortgage lender would typically issue a thirty-year mortgage and then patiently collect monthly payments for the life of the loan, by the dawn of the new millennium, financial "engineers" had figured out how to provide all kinds of variations on traditional mortgages, and to offer them through financial institutions that operated nationwide, with the payment streams sold to investors worldwide.

Even traditional mortgages were turned into new categories of investment securities that were then traded on globalized markets, with the buyers of those securities dependent on the representations of credit rating agencies that the underlying mortgages were safe and that the risk of default was computed accurately. ${ }^{129}$ As a further hedge against risk, financial institutions began to purchase insurance policies known as credit default swaps, which essentially were guarantees by other financial institutions that the holders of such swaps would be made whole if any securities unexpectedly failed to pay off.

This shadow-banking sector was, of course, just as interconnected as traditional banks have always been. ${ }^{130}$ In fact, the connections were more complex, and the aggregate dollar

128 Detalls of the now-famtliar story in the subsequent paragraphs can be found in many places. See, e.g., Daniel Sanches, Shadow Banking and the Crisis of 2007-08, PHILA. FED BUS. REv., Apr.-June 2014, at 7, 7-14 https://philadelphia fed.org/research.../brq2 14_shadow_banking.pdf [https://perma.cc/P3NK2VUN] ("One lesson of the financial crisis is that [the shadow banking system is] as vulnerable to panics as traditional banks because they are subject to similar risks."); Zoltan Pozsar, The Rise and Fall of the Shadow Banking System, MoodY's ECONOMY (July 2008), https://www.economy.com/sbs [https://perma.cc/Y7S8LEMJ) (describing the emergence of the shadow banking system as "the heart" of the financial crisis); Alan Moreira \& Alexi Savov, The Macroeconomics of Shadow Banking 1-4 (Yale Univ., Faculty Paper, 2016), http://faculty.som.yale.edu/ alanmoreira/Papers/ShadowMacro.pdf [https://perma.cc/C89T-KS9F] (explaining how shadow banking "bullds financial and economic fragility" and "sets up slow recoveries"). For a popular account, see generally MICHAEL LEWIS, THE BIG SHORT (2010) (detailing the creation of the credit default swap market and the Individuals who predicted that market's collapse and the ensuing financial crisis).

129 See supra note 128.

130 See supra note 128. 
amounts were in the trillions. These large portfolios were nonetheless deemed safe because analysts assessed the risk of default for any particular security as a statistically independent probability, isolated from the possibility of financial contagion. Or, to put it more simply, the financial engineers believed that all of the securities that they were creating were safe because if one security failed, all of the other securities would still be there. But it was only a matter of time before some securities would fail, and if the failure was significant enough, the interconnections between the various financial securities could start to unravel the system. ${ }^{131}$

Again, one can reasonably argue that the Fed should have seen these problems while they were emerging. Even though there is no obvious way to know when we have crossed over from a simple bull market to a bubble, the Fed might well have been in a position to tighten its regulations regarding these formerly unseen financial institutions. Of course, as we emphasize throughout this Article, the Fed does not act in a political vacuum, and there was a great deal of political pressure preventing the Fed and other agencies from tamping down these temporarily profitable opportunities. There was money to be made, and the political branches sided with those whose fortunes were dependent on a continued hands-off attitude by the Fed and other regulators.

At worst, then, the Fed can be blamed for being unwilling to risk its policy independence by taking actions that could have raised the ire of Congress and the Bush administration. Perhaps the Fed, like nearly everyone else at the time, also underestimated the risks. ${ }^{132}$ What is clear, however, is that the Fed not only stepped forward when the crisis erupted and quite literally saved the economy from collapse, but it was the only institution that could have done so, both practically and politically.

Once the financial crisis was set in motion by the collapse of Lehman Brothers and other shocking events, the ensuing financial panic wiped out trillions of dollars of notional value in the markets. One of the largest insurers of financial products, AIG, discovered that its business model was based on the

132 But not quite everyone. See LEWIS, supra note 128, at 1-25. 
flawed idea that not everything could go bad at the same time. But it could, and it did. ${ }^{133}$

In late 2008, there was serious question whether matters had already gotten so far out of hand that a second Great Depression was inevitable. As we noted in our Introduction, the political branches stepped forward with a combination of bailouts that prominently included the creation of the Troubled-Assets Relief Program (TARP). TARP, however, was worth only about $\$ 700$ billion, which was dwarfed by the trillions of dollars in paper wealth that were hanging in the balance. And because TARP alone created a political rebellion on the left of the Democratic Party and the right of the Republican Party, the political response was doomed to be inadequate. ${ }^{134}$

In that environment, the Fed was clearly the only institution that could be counted on to act in the interests of saving the system, rather than worrying about misplaced accusations of "bailing out losers." 135 Moreover, the trillions of dollars necessary to stop the contagion from spreading further simply did not exist. Only the Fed, with its unique ability to create new money when necessary, could do what was needed. As we discussed in Part II, ${ }^{136}$ there are prima facie plausible criticisms of the Fed for exceeding its statutory authority in pursuit of these policies, but such technical criticisms ultimately ignore the very nature of the Fed's role as lender of last resort.

Moreover, the Fed also knew that it possessed the ability to destroy money, which it could do if it found that the money that it had created threatened to create inflation. As it turned out, however, the new money had its desired effect with none of the bad possible side effects. Banks and other financial institutions were given sufficient funds to make it unnecessary to

133 See Carrick Mollenkamp et al., Behind AIG's Fall, Risk Models Failed to Pass Real-World Test, WALL ST. J. (Oct. 31, 2008 11:59 PM), http://www.wsj.com/ articles/SB122538449722784635 [https://perma.cc/2NTZ-RLLA].

134 The unpopularity of TARP on the populist right was a key element in the emergence of what is now known as the Tea Party movement. Bob Bennett, a conservative Republican U.S. Senator from Utah, voted to pass TARP. He then lost his party's nominating caucus in 2010 , ending his political career. Tea Party activists at the convention reportedly chanted derisively, "TARP! TARP! TARP!" to cheer Bennett's defeat. See Amy Gardner, Tea Party Wins Victory in Utah as Incumbent GOP Senator Loses Bid for Nomination, WASH. POST (May 9, 2010), http://www.washingtonpost.com/wp-dyn/content/article/2010/05/08/AR20 10050803430.html [https://perma.cc/R8S7-75A6].

135 If any institution is aware of the dangers of moral hazard, it is certainly the Fed because its regulatory mandate so clearly aims at discouraging financial arrangements that lead to increasingly risky behavior. Even so, the Fed's role also makes it aware that other factors must be balanced against such concerns.

136 See supra text accompanying notes 74-87. 
continue to sell off their financial holdings, stopping the contagion as other asset holders were not forced to sell their assets at fire sale prices. To the extent that the Fed's injection of liquidity was inadequate, it was largely because financial institutions sat on the money the Fed created, acting with newfound extreme caution to protect their own balance sheets from even the hint of risk. Rather than using the new money to restore prosperity, therefore, the bailed-out financial institutions simply held onto safe assets. The Fed had stopped the crisis, but the hope that the private sector would quickly resume normal activity went unfulfilled. ${ }^{137}$

In addition to pouring new money into the financial markets to contain the disaster that inadequate regulation had enabled, the Fed also deployed its key monetary policy tool to fight the Great Recession. Acting quickly, the Fed lowered its target interest rate in steps, setting a zero percent target beginning on December 16, 2008. ${ }^{138}$ The economy remained weak, and continuing to reduce interest rates is the standard response to a weakened economy. However, interest rates cannot be reduced below zero because (other than situations in which people will actually pay a financial institution to hold their money, in what amounts to purchasing a virtual vault) there is no reason to deposit money rather than hold onto it if the payoff is zero either way. ${ }^{139}$ Certainly, no one would give an institution money in exchange for the promise that the institution will return less money in the future. This is commonly known as the "zero lower bound." 140

Cutting its target interest rate to zero, therefore, was the most that the Fed could do, using its standard approach to

137 See Ben Protess \& Eric Dash, Many Banks Are Clinging to Billions of Bailout Money, N.Y. TIMES DEALBOOK (Mar. 18, 201 1, 9:31 PM), http://dealbook.nytimes. com/201 1/03/18/many-banks-are-clinging-to-billions-in-bailout-money/?_r=0 [https://perma.cc/LGG9-BJ5F].

138 See Joseph Lawler, Fed's Zero Interest-Rate Policy Stretches into Seventh Year, WASH. EXAMINER (Oct. 28, 2015, 2:34 PM), http://www.washingtonexamin er.com/feds-zero-interest-rate-policy-stretches-into-seventh-year/article/25 75117 [https://perma.cc/M5LV-48XR]; See Press Release, Bd. of Governors of the Fed. Reserve Sys. (Dec. 16, 2008), http://www.federalreserve.gov/newsevents /press/monetary/20081216b.htm [https://perma.cc/LAZC-MEJ4].

139 See supra note 110.

140 See R.A., The Zero Lower Bound in Our Minds, EConomisT (Jan. 7, 2012. 7:56 PM), http://www.economist.com/blogs/freexchange/2012/01/monetarypolicy [https://perma.cc/9MH4-8XEV]; see also Paul Krugman, How Negative Can Rates Go?, N.Y. Times: THE CONSCIENCE OF A LiBERAL (Mar. 3, 2015, 12:55 PM), http://krugman.blogs.nytimes.com/2015/03/03/how-negative-can-rates-go/ [https://perma.cc/6PRV-ZAJ9] (arguing that the lower bound is not precisely 0.0 percent for all borrowing, but the idea is the same). 
setting monetary policy. The hope was that the economy would quickly recover, and that the Fed could then move interest rates into a range within which it would again be possible to move rates up and down in anticipation of future fluctuations in the economy. Instead, because the economy has remained so disappointingly weak for so long, ${ }^{141}$ as of autumn 2016 , the Fed has only raised interest rates once since the onset of the Great Recession (from zero to 0.25 percent $^{142}$ in December 2015), although it has hinted at plans for further increases in the not-too-distant future. ${ }^{143}$

As we argue in Part IV, the main reason that the Fed has not been able to resume its historical role of prudently adjusting interest rates to smooth economic fluctuations is that the president and Congress have agreed to enact perversely contractionary policies that have slowed the economy's recovery. Moreover, these misguided fiscal policies have all but forced the Fed to do what it can to prevent the economy from sliding back into recession (and another potential financial crisis). The various waves of quantitative easing have seen the Fed redirect its asset purchases in a way that would provide some forward movement to the economy. Even those economists

141 Although the unemployment rate has recently fallen to levels that in the past would have suggested that the economy had reached full employment, other indicators that normally accompany a strengthening economy-in particular, robust wage increases and an increase in the growth rate of gross domestic product-have persistently falled to materialize. In the period since the official end of the Great Recession, the economy has stalled each time that it has shown some promise of accelerating. See Josh Bivens, Andrew Fieldhouse \& Heidi Shierholz, From Free-Fall to Stagnation 1-3 (Econ. Pol'y Inst., Briefing Paper No. 355, Feb. 14, 2013), http://www.epl.org/files/2013/bp355-five-years-after-start-of-greatrecession.pdf [https://perma.cc/HJ7D-HSQ9]; Jana Kasperkevic, US Economy Adds 173,000 Jobs as Unemployment Rate Drops to 5.1\%, GUARDIAN (Sept. 4, 2015. 8:42 AM), http://www.theguardian.com/business/2015/sep/04/us-econ omy-jobs-report-unemployment-drops-interest-rate [https://perma.cc/263QHV5X]; see also Ben Wolfgang, Low Unemployment Rate Obscures Decline in Americans Seeking Work, WASH. TIMES (July 7, 2015), http://www.washington times.com/news/2015/jul/7/unemployment-rate-drop-obscures-troubling-de cline-/?page=all [https://perma.cc/WHA2-KF86] (describing declining labor force participation rates). Therefore, the current low unemployment rate appears to be a false indicator (in part because so many people have dropped out of the labor force and not yet returned, which reduces the measured unemployment rate).

142 See Jeff Cox, Fed Raises Rates by 25 Basis Points, First Since 2006, CNBC (Dec. 16, 2015, 2:41 PM), http://www.cnbc.com/2015/12/16/fed-raises-ratesfor-first-time-since-2006.html [https://perma.cc/L9GP-KCUN].

143 See Binyamin Appelbaum, A January Pause, but Fed Affirms Plan for Gradual Rate Increases, N.Y. ThMES (Jan. 27, 2016), http://www.nytimes.com/2016/ $01 / 28 /$ business/economy/fed-interest-rates.html [https://perma.cc/U3EHE5PH]. We view even these anticipated modest rate increases as a bad idea at this point, given the failure of the economy's superficial strength to benefit most workers. See supra note 141 . 
who support the Fed in these efforts concede that the positive impacts have been modest, but something is still better than nothing. ${ }^{144}$

Disputes about the Fed's various policy choices aside, however, the important point here is that the Fed was the only institution in 2008 and 2009 that had the ability to create money - to be what central banks need to be, which is the lender of last resort. As it happened, a lot of money needed to be created, given the severity of the immediate crisis. And the Fed, even knowing that it is constantly in danger of running afoul of the predispositions of powerful politicians, stepped up and prevented the financial crisis from becoming a global depression.

We hope that the Fed will never need to take this kind of action again. At the very least, we ought to be able to count on our politicians not to create the threat of a crisis that only the Fed can prevent. As we shall see in subparts $B$ and $C$, however, there is a very real possibility that the Fed will be required to prevent a completely avoidable (and entirely politically inspired) train wreck.

\section{B. The Debt Ceiling and the President's Options During a Standoff}

A longstanding statute known as the "debt ceiling" purports to prevent the level of federal debt from rising above a specific dollar figure, specified in the statute. ${ }^{145}$ Prior to 2011 , this law was essentially a meaningless bit of feel-good legislation with no practical import. Although there had been occasions in previous decades in which the party in opposition to the then-sitting president would use the occasion of a required increase in the debt ceiling to offer patriotic speeches about the supposed irresponsibility of allowing the national debt to continue to increase, pretty much everyone knew that such grandstanding was meaningless political theater.

The problem was not necessarily that these politicians were insincere in their statements that they did not want the debt to rise. ${ }^{146}$ Indeed, as we discuss in Part IV below, one of

144 See Agustino Fontevecchia, FOMC: Fed Blames Congress and Obama for Slow Economy, Pledges Continued QE, FORBES (May 1, 2013, 2:23 PM), http:// www.forbes.com/sites/afontevecchia/2013/05/01/fomc-fed-blames-congressand-obamas-sequestration-for-slow-economy/ [https://perma.cc/5UZ4-UEW4]. 14531 U.S.C. \$ 3101 (2012).

146 Still, it is difficult not to suspect that insincerity and cynicism were, and are, in ample supply in fiscal policy debates. Many of the politicians who complain the loudest about the national debt refuse to vote to increase taxes at all, 
the major barriers to sensible policy in the current environment is the belief among so many politicians that budgetary austerity somehow will heal the economy's ills. The larger problem, then, is not that there are politicians who refuse to control the national debt, but that there are so few politicians who know (or are willing to admit) a point so basic that it underlay Hamilton's 1790 Report on the Public Credit, which in turn laid the foundation for America's eventual emergence as the world's largest economy-that some level of government debt is a virtue, not a vice, so that it would be an affirmatively bad idea to pay the federal government's debt down to anywhere near zero. ${ }^{147}$

In that sense, then, the status quo ante was an essentially harmless matter of political theater. ${ }^{148}$ Everyone knew that the already-passed spending and taxing laws required additional borrowing, and the occasional necessity to increase the dollar limit in the debt ceiling statute afforded everyone the opportunity to blame everyone else for our supposedly irresponsible fiscal policies. After a few days of speechmaking, the reality would return that the spending and taxing laws actually had to be executed as written, which necessarily meant updating the debt ceiling statute.

After the 2010 midterm elections, however, the new Republican majority in the House of Representatives seized upon a novel political strategy. Rather than simply conceding that the debt ceiling's level would need to be adjusted in light of congressional enactments, the new view was that the president could be accused of "wanting to increase the debt ceiling." And because a person who wants something must necessarily pay for it, the "price" of a debt ceiling increase would be for the president to agree to change one or more laws in ways that the House majority found appealing, but which they had not been able to achieve through normal legislative means. Although there was nothing logically limiting the Republicans' demands

and the spending cuts that they are willing to countenance are too small to make a serious difference. Opposing borrowing, apparently, means wishing that it were posstble to get something for nothing. Although we are pleased that these politicians have not succeeded in their stated goal of cutting spending sufficiently to reduce the national debt, we note the logical inconsistency of their positions.

147 See ALEXANDER HAMILTON, First Report on the Further Provision Necessary for Establishing Public Credit, in 7 THE PAPERS OF ALEXANDER HAMILTON 225-35 (Harold C. Syrett \& Jacob E. Cooke eds., 1963); see also Neil H. Buchanan, Why We Should Never Pay Down the Nattonal Debt, 50 U. LOUISVILLE L. REV. 683, 688-97 (2012) (arguing that many concerns about the national debt are misguided and explaining the advantages of having some government debt).

148 See Buchanan, supra note 147 , at 686 . 
to the realm of fiscal policy-they could, after all, have refused to increase the debt ceiling unless the president agreed to repeal environmental laws, or to support abortion restrictions, or anything else that the president would not otherwise supportin the summer of 2011 , the Republican leadership in the House announced that their party would not increase the debt ceiling without further cuts in federal spending, even though the House had only weeks before passed a continuing resolution that included spending cuts, and even though the bill that they passed would, as a matter of simple arithmetic, still require the debt ceiling to be increased. ${ }^{149}$

The White House responded to these demands by agreeing to negotiate with House leaders, narrowly averting a first-ever default on U.S. obligations in early August 2011 only by agreeing to a series of actions that ended in large, new cuts in current and future spending. ${ }^{150}$ In particular, after the failure of a bipartisan "super-committee" to agree on precisely targeted measures, the now-infamous "sequester" went into effect, resulting in automatic and indiscriminate cuts in domestic and military spending ${ }^{151}$ that continue to this day to limit the path of federal spending, even after legislation enacted in 2013 and 2015 to ease the sequester caps somewhat. ${ }^{152}$

Unsurprisingly, Republicans in Congress viewed their victory in the summer of 2011 as a template for the future. Senator Mitch McConnell, then the minority leader in the Senate, announced that the debt ceiling would henceforth be a bargaining chip, and that President Obama should expect to have to give something up if he wanted Congress to give him the authority to borrow more money. Because the 2011 agreement had increased the debt ceiling only to a level that would be sufficient for a little more than two years, given the (decreasing,

149 See Lori Montgomery et al., Origins of the Debt Showdown, WASH. POST (Aug. 6, 2011), https://www.washingtonpost.com/business/economy/originsof-the-debt-showdown/2011/08/03/gIQA9uqIzI_story.html [https://perma.cc/ DF6P-LRRN].

150 See id.

151 See Buchanan \& Dorf, How to Choose, supra note 8, at 1176-96.

152 See James Gao, Debt Ceiling Resolved, but Long-Term Budget Outlook is Bleak, U. CHI.: THE GATE (Nov. 30, 2015), http://uchicagogate.com/2015/11/30/ debt-ceiling-resolved-but-long-term-budget-outlook-is-bleak/ [https:// perma.cc/UK8R-F3RT]; see also David M. Herszenhorn, Congress Strikes a Budget Deal with President, N.Y. TiMEs (Oct. 26, 2015), http://www.nytimes.com/ 2015/10/27/us/politics/congress-and-white-house-near-deal-on-budget.html [https://perma.cc/XVZ9-NA8U]. 
but still positive) annual budget deficit, the next debt ceiling political standoff was baked into that legislation. ${ }^{153}$

Before that next drop-dead date was reached, the authors of this Article wrote a series of articles in which we argued that the president would be justified in announcing that the debt ceiling statute is unconstitutional, and that he would therefore refuse to allow the debt ceiling to prevent him from carrying out his duties under the spending and revenue laws. ${ }^{154}$ We coined the term "trilemma" to describe the president's impossible position, should Congress refuse to increase the debt ceiling. If federal debt reached the statutory ceiling at any given time, and the difference between legislated expenditures and tax revenues was, say, $\$ 50$ billion, then the president would be required either to: (1) collect $\$ 50$ billion more in taxes than Congress had (via the Internal Revenue Code) ordered him to collect; (2) spend $\$ 50$ billion less than Congress had (via the appropriations laws) ordered him to spend; or (3) borrow $\$ 50$ billion more than Congress had (via the debt ceiling statute) authorized him to borrow.

Because each prong of the trilemma would require the president to usurp an enumerated power of Congress, any path that the president chose would violate the Constitution. We argued, however, that it was possible to rank the three unconstitutional choices, and we concluded that the president would do the least constitutional damage by honoring Congress's commands regarding spending and taxing, which he could only do by setting aside Congress's contradictory command regarding debt. If Congress disagreed with the president's choice to borrow the necessary amount of money to avoid a default on the government's obligations, it retained the power to change future spending and tax levels to achieve the level of debt that it desired.

The conventional wisdom in policy circles holds that faced with a shortfall caused by reaching the debt ceiling limit, the president ought to unilaterally withhold payment on spending obligations as they come due, but we argued (and still contend) that this conventional wisdom is wrong. For the president to arrogate to him- or herself the power to change Congress's spending priorities-honoring some of Congress's expressed

153 See Jennifer Depaul \& Eric Planin, McConnell Turns Debt Ceiling into a Political Football, FISCAL TIMES (July 12, 201 1), http://www.thefiscaltimes.com/ Articles $/ 2011 / 07 / 12 /$ McConnell-Turns-Debt-Ceiling-Into-a-Political-Football [https://perma.cc/F3F6-7DDP].

154 See supra note 8. 
wishes while frustrating others-would undo so much of the legislative branch's negotiated compromises that the constitutional structure cannot permit it. As now-Chief Justice John Roberts once wrote: "Separation of powers is a zero-sum game. If one branch unconstitutionally aggrandizes itself, it is at the expense of one of the other branches." 155 The degree of executive aggrandizement that would follow from a president's decision to reset Congress's spending priorities is simply too great, compared to the alternatives. The president should not be allowed or expected to use the debt ceiling statute as a reason to ignore Congress's hard-fought budgetary compromises, and instead to decide which bills to pay and which to ignore or delay.

Notwithstanding our analysis, the Obama White House endorsed the conventional wisdom that the president would have no choice but to usurp Congress's spending power by refusing to make required payments to the government's obligees, if Congress ever fails to make a timely adjustment in the debt ceiling. ${ }^{156}$ This decision might well have been based on savvy political strategizing. For example, the White House might have feared that the president could be accused of "wanting to borrow money," or that he has "blown through the debt ceiling," or similar baseless-but potentially potent-political attacks. Whatever the political reasons, however, there is no evidence that the Obama Administration was ever seriously contemplating following our advice.

President Obama did, however, change his political strategy after losing his first debt ceiling battle, in the summer of 2011. Rather than accepting the idea that an increase in the debt ceiling was a desirable goal in itself, for which he had to pay a political price, he pointed out (correctly) that the debt ceiling must be increased simply in order to prevent the federal government from defaulting on obligations to which it was already legally committed. To be able to pay our bills, the president took the position that the debt ceiling was nonnegotiable. ${ }^{157}$ Neither side wanted to increase the debt ceiling, as a matter of policy commitments, but both sides were respon-

155 John G. Roberts, Jr., Article III Limits on Statutory Standing, 42 DuKE L.J. 1219,1230 (1993).

156 See Buchanan \& Dorf, Nullifying the Debt Celling Threat, supra note 8, at 242-48 (2012).

157 See, e.g., Nell Irwin, Does Raising the Debt Ceiling Increase the Debt?, WASH. POST: WONKBLOG (Oct. 8, 2013), https://www.washingtonpost.com/news/ wonk/wp/2013/10/08/does-raising-the-debt-ceiling-increase-the-debt/ [https://perma.cc/T5FX-AKF7] (quoting President Obama and drawing an analogy to personal finance). 
sible for increasing it to the level that would be required to allow the nation's obligations to be met. The president thus drew a line in the sand, saying that he would accept only a "clean" debt ceiling increase, and that he would not negotiate over unrelated issues in order to adjust the nominal limit in the debt ceiling statute. ${ }^{158}$

As far as it went, the president's revised approach was clearly correct. The debt ceiling statute is simply not relevant to determining how much debt the government issues. Members of Congress who (wrongly, in our view) think that the deficit should be zero, or who even believe that the debt should be paid down (which would require annual surpluses, probably for decades to come) have the legislative means necessary to make that happen through the normal budgetary process. The debt ceiling is thus not about changing the amount of debt, but about making it impossible to finance the debt that Congress has already put in place.

As we argued in our most recent article, once there are spending and taxing laws in place that imply the need for deficit financing, the government will have to take on that new debt by issuing formal Treasury securities, or it will instead borrow the money without calling it debt by telling its obligees that they must wait to be paid. Either way, once the spending and taxing laws have been passed, the die is cast, and the debt will rise above the level specified in the debt ceiling statute, whether Republicans in Congress admit it or not. The only way around this conclusion, we noted, would be for the president to take the radical (and unconstitutional, even on the narrowest reading of the relevant provisions) step of repudiating its obligations outright. 159

In that sense, then, the president was correct to say that Congress has no choice under the Constitution but to increase the debt ceiling when appropriate (or, even better, to repeal the debt ceiling statute entirely), and to stop trying to use that law as a political battering ram.

In addition, as a matter of political strategy, one could understand why the president would loudly announce his new commitment not to sign a bill raising the debt ceiling if it in-

158 See Jim Acosta et al., Obama Says He'd Talk on GOP's Terms-If They Raise Debt Ceiling, Fund Government, CNN (Oct. 9, 2013, 6:22 AM), http:// www.cnn.com/2013/10/08/politics/shutdown-showdown/ [https://perma.cc/ HQ3P-SFSN] (quoting President Obama refusing to accede to Republicans' "ransom" demands in exchange for paying the government's bills).

159 See Buchanan \& Dorf, Borrowing by Any Other Name, supra note 8, at 28-33. 
cludes any other provisions. As in the deadly game of "chicken," such a "stare-down strategy," as we call it, can only work if the other side knows in advance that the president is fully committed to staying the course. The congressional Republicans' only choice at that point is to test the president's level of commitment. As it happens, President Obama's opponents did indeed blink each time that a debt ceiling increase was required in the post-2011 era, agreeing each time to increase the debt ceiling (or, in some cases, to "suspend" the debt ceiling temporarily, and then reset the limit to a higher level when the ceiling is later reinstated) and thus avoid a default on the government's obligations. In that sense, President Obama "won" the post-2011 debt ceiling standoffs. However, there is no guarantee that his successor will prevail in future standoffs, the first of which could occur in early 2017, when the debt ceiling will next need to be raised. ${ }^{160}$ Ominously, in February 2016, House Republicans released a report that strongly suggests that they continue to think that failure to raise the debt ceiling would impose no special hardship-and certainly no constitutional crisis-for the executive branch: they apparently regard the stare-down strategy as a bluff that they are now prepared to call. ${ }^{161}$

Thus, there was and continues to be an enormous danger inherent in the stare-down strategy. Imagine that the next president secretly agrees with our analysis, and thus that he or she would be willing-if Congress ultimately refuses to blink during a future stare-down-to issue new debt in order to honor Congress's dictates regarding spending and taxing. At what point would the president be able to announce that he or she is going to issue new debt? Announcing his or her fallback strategy before the very last second would allow opponents in Congress to blame him or her in exactly the way that the president would hope not to be blamed, which would supposedly weaken him or her in the competition for public approval (and

160 See Joseph Lawler, Deal Would Suspend Debt Ceiling Until After 2017 Inauguration, WASH. EXAMINER (Oct. 27, 2015, 9:41 AM), http://www.washingtonexam iner.com/deal-would-suspend-debt-celling-until-after-2017-inauguration/arti cle/2574984 [https://perma.cc/2HDN-DRHF].

161 See StafF OF H. COMM. ON Fin. SERVS., SubComm. on OVERSight and INVEsTi-

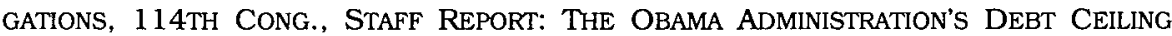
SubTERFuge: SubPOENAED DOCUMENTS REVEAL TREASURY MisLED PUBLIC IN ATTEMPT TO "MAXIMIZE PRESSURE ON CONGRESS" 16-22 (Feb. 1, 2016), http://financialservices. house.gov/uploadedfiles/debt_ceiling_report_final_01292015.pdf [https:// perma.cc/MKB7-DQYA]. As the report's title indicates, House Republicans believe that the Obama Administration had contingent plans to prioritize payments, and that the stare-down strategy was therefore a bluff. 
of finger pointing). Meanwhile, the stare-down strategy's likelihood of working is at its highest as the clock ticks toward midnight on the drop-dead date, as congressional opponents become convinced that the president will refuse to blink.

Yet waiting until the witching hour to announce the issuance of debt-ceiling-violating debt would create serious technical implementation issues. Normally, the sale of new debt securities in a standard bond auction (which is the method by which the federal government borrows money) is announced weeks in advance, and the process plays out over hours or days. If the president is strategically committed to waiting until the last possible second, however, he or she would be unable to authorize the necessary auction in time to prevent a default. The federal government must pay bills that come due every day, and if sufficient tax revenues do not come in on that day, abiding by the debt ceiling would leave the Treasury with no way to pay the people to whom the government owes money. On the drop-dead date, bills would come due that could only be paid by borrowing money, yet the money would not yet have been borrowed, and it would be logistically impossible to hold a timely bond auction.

Importantly, when we describe such an event as a "firstever" default on the government's obligations, we also mean to emphasize the gravity of such an unprecedented event. The U.S. government is considered the safest borrower in the world, and its reputation for sound finances is based on the fact that no one has ever been denied payment in full on the date that the federal government has legally committed to making a payment. The United States has never said, "sorry, I'll get it to you in a few days." People and businesses to which the government owes money count on timely and complete payments, and they make further commitments on that basis. Missing payments by even a day is no small matter.

In short, the stakes in a debt ceiling stare-down are incalculably high. The federal government's future ability to borrow, to enter into contracts, and its very ability to continue to conduct its affairs in a businesslike fashion would be harmed by any failure to pay its obligations. That is not to say that people would henceforth refuse to do business with the government, or to lend it money, but just like any other borrower with a tarnished credit rating, the government would see its future borrowing costs rise. And the shame of it is that these increased costs to be borne by taxpayers are completely avoidable. 
Therefore, the danger of a presidential debt ceiling staredown strategy is that, if neither side blinks, it would be too late for the president to adopt a new strategy that would both minimize the constitutional violation and save the nation's creditworthiness. Fortunately, there is one way out. Unfortunately, relying on the needed deus ex machina would be extraordinarily dangerous.

\section{The Dangers of Requiring the Fed to Use Its Full Powers}

As we described above, the Federal Reserve's most important duty is to protect the financial markets, and ultimately the economy. Usually, this means that it must act as the lender of last resort for financial institutions, as we described in subpart A, above. Here, however, we see the possibility that the Fed could be the only lender that could act quickly enough to prevent the debt ceiling from creating a default on some of the government's obligations.

The Fed's concern in this instance would not only be based on the idea that the government's future borrowing costs would rise in the aftermath of a default. The Fed would also be required to consider the immediate effects on financial markets, if the United States were to default on any of its legally required payments between the expiration of the deadline to raise the debt ceiling and when a sale on the open market of what we have previously called "Presidential bonds" could be implemented. ${ }^{162}$ Even assuming that banks, foreign governments, and other financial players could eventually be found to buy the bonds (at an appropriate interest premium reflecting the cloud on their legality), such purchases would come too late to avoid default. In the meantime, financial actors, both at home and abroad, would likely respond to the initial default by taking protective measures, reducing their exposure and thus cutting off financial transactions that they would otherwise have been quite willing to consummate. The risk of financial contagion would be quite real.

In these circumstances, the Fed might well decide that it should intervene and immediately buy the new bonds itself. It

162 We previously used the term "Presidential bonds" to emphasize that the president would need to issue Treasury securities that had not been authorized by Congress. See Buchanan \& Dorf, How to Choose, supra note 8, at 1209. Because that distinction is not the focus of our analysis here, we will not continue to use that term. Instead, we simply point out that the president would be required to issue new bonds, in order to borrow enough money to pay the bills that Congress's previous spending and taxing laws require. 
would need to purchase enough Treasury securities-at midnight on the drop-dead date-to allow the federal government to avoid its first-ever default. For these purposes, the Fed's independent status is key because it counts as "the public" when it buys securities from the Treasury. ${ }^{163}$ Although it would be buying those securities-that is, lending to the government-with money that it created of its own volition, that would not be extraordinary, and there is nothing about the Fed's actions here that would be any different from any other time that it indirectly increases the money supply (such as its standard approach to lowering interest rates in the face of a weak economy). The important point is that the Treasury would receive the money that it needs to pay all of its obligees, in full and on time.

Here, of course, the Fed would know that there are no good choices. The markets would be in some amount of turmoil in any event, and the Fed's intervention would itself create uncertainty (and no small amount of acrimony). However, because the Fed is the only institution that would be capable of acting fast enough and decisively enough to prevent the country from permanently damaging its credit rating, we would expect the politically independent Fed to step in to save the day, and to save the nation from the irresponsible actions of those politicians who would have tried to use an unconstitutional statute to achieve political ends that they cannot otherwise achieve.

Indeed, we believe that the Fed would be required to buy the Treasury's new bonds in such a situation, in order to meet its primary responsibility of protecting the stability of the financial markets. But even if we are wrong, and the people who are then in charge of the Fed choose not to intervene, that would merely mean that they have concluded that the consequences of a first-ever default are outweighed by other considerations. Having an institution in place that possesses the political independence that would allow it at least to consider following our advice-rather than being subject to political supervision-is precisely why we believe that the Fed's independence is so important in a crisis. It might not always make the tough calls that other people might want it to make, but it would nonetheless be empowered to act on its best judgment.

Note, however, that even if the Fed were to follow our advice, the debt limit would still have been breached, precisely

163 See Understanding the Federal Debt, U.S. Gov'T ACCOUNTABILITY OFF., http:/ /www.gao.gov/fiscal_outlook/understanding_federal_debt/interactive_graphic/ components_of_federal_debt [https://perma.cc/Y4W2-W544]. 
because the Fed counts as "the public" when it lends money to the government, and it would be holding more Treasury securities than it held before, increasing the total outstanding debt above the statutory limit. Nonetheless, as we noted above, that ship would have sailed when Congress enacted spending and taxing laws that imply borrowing in excess of the debt ceiling. The president would still have faced a trilemma and would thus violate the Constitution's separation of powers by authorizing the Treasury Department to borrow money from the Fed. As we have emphasized, however, because this is the least unconstitutional of the president's three options, it is the least bad choice from a set of only bad options. And at the point where it became clear that the stare-down strategy had resulted in a stalemate, the Fed would be the only institution that could allow the president to come close to meeting his or her constitutional obligations-and, of course, to minimizing the damage to the financial system and the economy.

Even so, if the Fed were to follow our advice, it would open itself up to charges that it had taken sides with the president in a partisan fight. Even though it would not have made its decision for political reasons, it would have been forced to choose to anger either Republicans or Democrats. And this is no small matter. As we described in Part II, the Fed is already under constant attack for its activities, with "end the Fed" and "audit the Fed" efforts now afoot in Congress, as the latest incarnations of the undying distrust of central banks that seems always to exist just outside the political mainstream.

Here, the action that the Fed would be obligated to takebuying bonds that have not been authorized by Congress in order to prevent a federal default-would not only stoke the fears of "unaccountable" bankers working behind the scenes, but would also feed into one of the central complaints on the political right: that the Fed is "enabling the growth of the federal debt." 164 As noted above, the Fed carries out its mandate to control interest rates and monetary aggregates by buying and selling Treasury securities. It would be possible for the Fed instead to buy private financial assets such as corporate stocks and bonds, but it is difficult to imagine that this would make the Fed's populist critics feel any better. After all, do they really

164 Binyamin Appelbaum, Challenged on Left and Right, the Fed Faces a Decision on Rates, N.Y. TIMES (Aug. 30, 2015), http://www.nytimes.com/2015/08/ 31 /business/challenged-on-left-and-right-the-fed-faces-a-decision-on-rates. html [https://perma.cc/ZE6W-75VD]. 
want the Fed to hold ownership stakes in corporate America or to be a creditor to American businesses?

In any event, the current reality is that the Fed pushes new money into the financial system by buying and holding U.S. Treasury securities. This, in turn, can easily be mischaracterized as "fund[ing] Washington's deficit spending." 165 Even though the debt ceiling itself has nothing to do with the growth of the debt, the superficial logic would go something like this: The Fed already finances the debt. The Democrats want more debt. The debt ceiling would stop them from issuing it. The president is refusing to negotiate to reduce spending and thus reduce the debt. The Fed has just proved that it is on the president's side by allowing the president to illegally ignore the debt ceiling.

This possibility suggests that the Fed could have to choose between following its best judgment and maintaining its political independence. The Fed might well agree with us that the best measure to take, should Congress insist on creating a trilemma for the president, is to buy the new Treasury securities that would be issued on the drop-dead date. Yet it would have to weigh against that policy judgment the possibility that it could be signing its own death warrant because enraged opponents could seize on its actions to justify legislation curtailing Fed independence or eliminating the Fed entirely.

In short, the possibility that some members of Congress will again force a debt-ceiling showdown, combined with the decision of a future president to use a stare-down strategy, could result in a crisis that is in some sense tailor-made for an independent central bank to step in and solve. Yet the result of such a situation could be either that the Fed does the right thing at the expense of its own independence, or that it does the wrong thing to protect that independence. Given the stakes, and the importance of the Fed in serving as an independent but accountable institution, it would be better if the Fed were never to face such a choice.

We are aware, of course, that in some sense our analysis here could be used as a roadmap to guarantee the Fed's destruction. For someone who is determined to "end the Fed," after all, we have described how a deliberately concocted debt-

165 Ylan Q. Mui, Conservatives Have Falled to End the Fed, but They're Not Giving Up Hope, WASH. POST: WONKBLOG (Sept. 2, 2015), http://www.washington post.com/news/wonkblog/wp/2015/09/02/conservatives-have-failed-to-endthe-fed-but-theyre-not-giving-up-hope/ [https://perma.cc/PVJ8-CCR2] (noting various criticisms of the Fed, including its supposed funding of deficit spending). 
ceiling crisis could not only serve the purpose of putting the president in a political bind, but it could also set in motion the Fed's final demise. We have no doubt that there are those who would be willing to bet the country's future and roll the dice (although we dearly hope that there are not enough of those people actually to make it happen). Even so, we do not view our role as analyzing an issue but then hiding unwelcome conclusions. Moreover, our analysis here shows even more clearly why a president's decision to adopt a stare-down strategy, rather than confronting well in advance of a debt-ceiling standoff the reality that the debt-ceiling statute is unconstitutional, is such a dangerous game.

Beyond the cautionary tale that comes from this possible series of events, the larger issue is whether the Fed should continue to exist as an independent policy actor. This really boils down to the question of whether we want the Fed to be able to exercise human judgment. Although we would never want the Fed to be forced to decide whether to rescue the economy during a debt ceiling standoff, that it could do so serves as an important example demonstrating the unique role that the Fed serves in the U.S. political and economic system. It is precisely when the political branches are incapable of responding to a crisis-either because of the rush of events, or because the political process has ground to a halt-that we would most need a politically independent Fed to do what otherwise could not be done.

\section{IV}

\section{JUSTIFYING FED INDEPENDENCE}

We have just seen the value of Fed independence in a crisis-both a recent real one and a potential near-future one. Yet the Fed acts as an independent agency in normal times as well as during crises. Can Fed independence be justified in normal times?

In our view, during the years since the financial crisis the Fed made better macroeconomic policy choices than the political branches did. Whereas the latter deployed expansionary fiscal policy too timidly during the crisis and then pivoted to deficit reduction well before the economy had fully recovered, the Fed pursued an aggressive, expansionary monetary policy. ${ }^{166}$ Yet the fact that an expert agency pursues better poli-

166 MARC LABONTE, CONG. RESEARCH SERV., RL30354, MONETARY POLICY AND THE FEDERAL RESERVE: CURRENT POLICY AND ISSUES FOR CONGRESS 13-17 (2015). 
cies than those pursued by political actors is not, standing alone, a sufficient reason to insulate that agency from political supervision. If it were, then we would have reasons to favor technocracy presumptively across a wide range of subject matter areas.

Accordingly, the case for Fed independence in ordinary times must rest on something beyond the superior substantive competence of Fed economists relative to elected officials. Conventionally, that something is thought to be the risk that, if given control over monetary policy, elected officials-especially the president-will use that control to boost the economy in the short term so that the voters reward them, even as the best approach for the long-term health of the economy would be tighter money. Yet the experience of recent years reverses the conventional wisdom. More commonly now, elected officials favor tighter monetary policy than the Fed. ${ }^{167}$ The conventional justification for Fed independence in normal times appears to be out of date.

This Part nonetheless defends Fed independence by emphasizing that times change. No one thinks that Americans' generally healthy regard for freedom of speech justifies eliminating the First Amendment, so, likewise, the fact that we live in a period when the roles of the Fed and political actors are upside-down does not mean that the traditional relation will not reappear. A structural defense of institutional independence should be based on the long-term incentives of the actors. In elaborating this point, we draw on an analogy between an independent judiciary and an independent central bank. We also emphasize a distinctive justification for Fed independence based on our consideration of the Fed's performance in recent years and its potential role in responding to future crises. ${ }^{168}$ Fed independence from the political branches of the government does not merely enable the Fed to check them or to act on its own. Rather, Fed independence facilitates cooperation with the rest of the government because the Fed can act as a financial counterparty to the political parts of the government

167 See Matt O'Brien, Why Republicans Are Getting One of the Most Obvious Things Wrong, WASH. POST: WONKBLOG (Nov. 10, 2015), https://www.washington post.com/news/wonk/wp/2015/11/10/why-republicans-are-getting-one-ofthe-most-obvious-things-wrong/ [https://perma.cc/TK5R-8S3R]; see also Michael Grunwald, Republicans Want Us to Be Europe, TIME (Apr. 3, 2014), http:/ /time.com/49010/republicans-want-us-to-be-europe/ [https://perma.cc/7YHYXPSC] (describing similarities between Republican monetary policies and postcrisis European austerity measures).

168 See supra Part II. 
(especially the Treasury), in both normal times and emergency times.

\section{A. From Expertise to Self-Dealing}

In an important speech two decades ago, administrative law scholar Peter Strauss explained how, over time, the chief rationale for delegation of substantial power to administrative agencies shifted from expertise-the notion that complex technical questions call for solutions fashioned by objective experts-to politics-the recognition that agencies make policy choices constrained by public input and presidential supervision. ${ }^{169}$ The leading administrative law doctrine of our era, Chevron deference, reflects that shift: in the eponymous case, the Supreme Court sustained the Reagan Administration's loosening of the emissions rules governing power plants on the ground that, within the broad linguistic bounds of the relevant statutory delegation, an agency may (indeed must) make policy choices, but that ultimate supervision by the president ensures political accountability for those choices. ${ }^{170}$

To be sure, comparative expertise continues to play a role in justifying delegation to administrative agencies. When Congress paints with a broad brush, the case law assumes that, other things being equal, it intends that agency experts rather than generalist judges will fill in the details. ${ }^{171}$

In addition, recent scholarship calls attention to an institutional dimension to agency expertise. In the traditional pic-

169 See Peter L. Strauss, From Expertise to Politics: The Transformation of American Rulemaking, 31 WAKE FOREST L. REV. 745, 755-56 (1996) (describing shift in 1960 s and 1970s as reflecting "a general social trend that came to view agencies less as apolitical 'experts' administering a strictly rational process, and more as political bodies making choices among alternatives in response to social needs and political inputs").

170 The Court stated in Chevron, U.S.A., Inc. v. Natural Res. Def. Council, Inc., 467 U.S. 837, 865 (1984), that "an agency to which Congress has delegated policymaking responsibilities may, within the limits of that delegation, properly rely upon the incumbent administration's views of wise policy to inform its judgments. While agencies are not directly accountable to the people, the Chief Executive is, and it is entirely appropriate for this political branch of the Government to make such policy choices ...."

171 See id. ("Judges are not experts in the field . . . .); Talk Am., Inc. v. Mich. Bell Tel. Co., 131 S. Ct. 2254, 2265 n.7 (2011) (explaining, in the course of deferring to an agency's construction of its own rule that the existence of a "technical factual dispute" between the parties "simply underscores the appropriateness of deferring [because s]o long as the [agency] is acting within the scope of its delegated authority and in accordance with prescribed procedures, it has greater expertise and stands in a better position than this Court to make the technical and policy judgments necessary to administer the complex regulatory program at issue here"). 
ture, courts (and others) would give epistemic deference to experts because, in virtue of their training and experience, they know more about the underlying technical issues than the layperson. The new work on agency expertise supplements this view of expertise "in the air" by describing how specialized training and experience interact with a particular institutional setting. As Matthew Stephenson helpfully summarizes this perspective using what he himself calls "the jargon of modern social science, public decisionmakers' expertise about policy decisions is often endogenous (produced by factors internal to the legal-institutional system) rather than exogenous (determined by factors external to, and therefore independent of, legal-institutional design choices)." 172 In other words, agencies do not merely collect experts under one roof where they exercise their pre-existing expertise; the agency and its professional staff co-produce expertise.

This new attention to how agencies produce and exercise expertise arguably justifies restoring some of the lost luster of expertise as a justification for both delegation of authority to agencies and judicial deference to agency decision-making. At the same time, however, the factors that Strauss identified as leading to the earlier shift from expertise to politics have hardly disappeared. Agencies remain susceptible to capture by the industries they regulate, ${ }^{173}$ and many decisions delegated to agencies involve trading off values that are matters of political contestation. Perhaps the most that can be said is that the case for delegation and deference to agencies rests on an uncertain and context-dependent mix of expertise and politics.

We take no position on the precise proportions of that mix in any given setting or more broadly. Our point here is that, whatever the mix in any particular context, something extra must be offered to justify structuring an agency to be relatively independent of political oversight. In principle, that something could be the extraordinarily technical nature of the underlying subject matter, but in practice, that sort of justification cannot explain the haphazard pattern of supervision that Congress has in fact devised. Indeed, there is not even agreement on which agencies count as independent ${ }^{174}$ or whether one can

172 Matthew C. Stephenson, Information Acquisition and Institutional Design, 124 HARV. L. REV. 1422, 1426 (2011).

173 See Strauss, supra note 169, at 756 (describing risk of capture as part of the process by which agency decision-making came to be seen as polltical).

174 See Miroslava ScholTEN, THE POLITICAL ACCOUNTABILITY OF EU AND US INDEPENDENT REGULATORY AGENCIES 200-01 (2014) (noting that "no general definition of 'independent regulatory agency' exists" but nonetheless listing sixteen such agen- 
sensibly draw a sharp distinction between independent and executive-branch agencies. ${ }^{175}$

But even treating "independence" as a matter of degree rather than kind, it is plain that the degree to which the relevant regulatory subject matter calls for technical skill cannot, by itself, explain why Congress chooses to make some agencies more or less politically accountable. For example, environmental regulation requires extraordinarily complex scientific judgments, yet the Administrator and deputy Administrators of the Environmental Protection Agency are political appointees heading an agency within the executive branch. ${ }^{176}$ Likewise, the Energy Department, which has responsibility for many highly technical matters, ${ }^{177}$ is an executive agency. At the same time, however, the Federal Energy Regulatory Commission and the Nuclear Regulatory Commission have the usual indicia of independent agencies. ${ }^{178}$

Thus, the technical skill needed to regulate an area cannot have been the decisive criterion in Congress's decisions whether to make particular agencies subject to direct political control versus relatively independent. And accordingly, the need for technical expertise does not provide a sufficient expla-

cies based on the list set forth by statute, 44 U.S.C. $\$ 3502$, and objective indicia of independence such as "multi-member management boards, bipartisan criteria for appointment and the removal 'for cause' restriction"). But see Note, The SEC Is Not an Independent Agency, 126 HARV. L. REV. 781, 785-93 (2013) (arguing that members of the Securities and Exchange Commission, which appears on Scholten's list of independent agencies, do not enjoy for-cause dismissal protection and that the Commission is thus not independent).

175 See, e.g., Rachel E. Barkow, Insulating Agencies: Avoiding Capture Through Institutional Design, 89 TEX. L. REv. 15, 17 (2010) (arguing that "conventional discussion of administrative law and agency design has overlooked [the fact] that the traditional metrics for an independent agency" ignore various structural means of insulating agencies); Kirti Datla \& Richard L. Revesz, Deconstructing Independent Agencies (and Executive Agencies), 98 CORNELL L. REV, 769, 825-27 (2013) (finding that no list of functional criteria satisfactorily distinguishes executive from independent agencies and concluding that independence should be regarded as a multi-factor matter of degree); Adrian Vermeule, Conventions of Agency Independence, 113 CoLUM. L. REv. 1 163, 1165 (2013) (arguing that "unwritten political norms" or "conventions," rather than criteria such as insulation of agency personnel from removal by the president, define which agencies are "independent").

176 See, e.g., Clean Water Act, 33 U.S.C. $\$ 1313$ (2012) (prescribing standards for water quality and implementation plans); see also, e.g., 40 C.F.R. $\$ 130.7$ (2016) (identifying the total maximum daily loads (TMDL) and individual water quality-based effluent limitations).

177 For example, the Department of Energy has responsibility for managing nuclear weapons and nuclear energy. See Nuclear Security \& Nonproliferation, ENERGY.GOV, http://energy.gov/public-services/national-security-safety/nuclear-security-nonproliferation [https://perma.cc/8H2J-TJBZ].

178 See SCHOLTEN, supra note 174, at 200. 
nation for the Fed's independence. Yes, regulation of the macro-economy through the purchase and sale of financial assets requires considerable technical expertise, but certainly not more technical expertise than the sorts of tasks undertaken by some more politically accountable agencies.

In any event, strictly as a normative matter, the need for expertise should not suffice as a reason for an agency's independence from political oversight. To justify creating an independent agency, Congress should have some special reason beyond subject matter difficulty. Otherwise, given the complexity of just about everything, Congress would be justified in delegating nearly all regulation to independent agencies.

We recognize that virtually no body of constitutional doctrine governs the question of when Congress can, and when it cannot, delegate power to an independent as opposed to an executive-branch agency. The issue arises, if at all, only indirectly, typically in cases challenging congressional restrictions on the president's power to remove officers wielding government power. ${ }^{179}$ Yet those cases make no serious effort to distinguish between the sorts of responsibilities that can be assigned to agency officials who are relatively insulated from political pressure and those that must be entrusted to officials directly answerable to the president. ${ }^{180}$

Accordingly, when we ask whether Fed independence can be justified, we do not mean to inquire whether Fed independence is constitutionally permissible. Under the current doctrine, the answer to that question is pretty clearly yes. Perhaps the doctrine ought to be modified so that, in Gillian Metzger's turn of phrase, the president has a "duty to supervise" the administrative state. ${ }^{181}$ If so, that duty might be calibrated to take account of the particular mission and characteristics of each of the various agencies of government.

For present purposes, however, our task is sufficiently complicated even when we employ the simplifying assumption

179 See, e.g., Free Enter. Fund v. Pub. Co. Accounting Oversight Bd., 561 U.S. 477, 495-98 (2010) (invalidating double level of for-cause protection for members of board created by Sarbanes-Oxley Act); Morrison v. Olson, 487 U.S. 654, 685-96 (1988) (upholding restrictions on removal of independent counsel).

180 Myers v. United States, 272 U.S. 52 (1926), which invalidated restrictions on the president's power to fire a postmaster, is an exception, as the Court there reasoned that all principal officers exercising executive power must be subject to direct presidential removal, but the logic of Myers has not been followed in subsequent cases. See Morrison, 487 U.S. at 723-26 (Scalia, J., dissenting).

181 Gillian E. Metzger, The Constltutional Duty to Supervise, 124 YALE L.J. 1836, 1842-43 (2015) (rooting such a duty in the Take Care Clause and separation of powers, notwithstanding worries about judicial competence). 
that there are just two kinds of agencies: executive agencies that answer to the president and independent agencies that are less directly accountable to political oversight. Any plausible classificatory scheme would put the Fed in the second category. Accordingly, when we ask whether Fed independence is justified we mean simply whether Congress had a good reason for thinking that the Fed needs the kind of independence it enjoys ${ }^{182}$ - that is, whether the Fed is special in some way. This is why, in order to avoid the slippery slope to technocracy tout court, a good answer would have to point to something other than the expertise of Fed economists.

The standard answer in the literature on the Fed (and central banks more generally) is the risk that politicians will manipulate the money supply for short-term political ends at the expense of long-term economic health. ${ }^{183}$ In the United States, the clearest example is the pressure that President Richard Nixon applied to Fed Chair Arthur Burns. ${ }^{184}$ That Nixon was able to apply such pressure notwithstanding the Fed's institutional insulation only underscores the danger we would face if the Fed were subject to more direct political control.

The next subpart raises questions about the continuing vitality of this justification for Fed independence, but for now we note that it bears a strong structural resemblance to the standard justification for an independent judiciary with the power of judicial review. Constitutions mark the boundaries of government's authority-whether at the border of other branches or levels of government or of individual rights-and so there is a risk of self-dealing if the very government officials, whose actions a constitution constrains, have final authority

182 We mean independence from the president and Congress. Rachel Barkow has argued that insulating agencles from direct control by political actors can be a means of avolding agency capture, that is, of making the agency independent of the influence of private actors. See Barkow, supra note 175 , at 17 . We take no position on whether avoiding capture justifies agency independence, but we do note that this interest would not appear to provide the "something extra" that we believe is needed because there is a risk that just about any agency will be captured. Perhaps, however, some agencies are substantially more vulnerable to capture than others. If so, this greater susceptibility might warrant independence.

183 Conti-Brown explains that this picture is widely known through two metaphors: Ulysses bound to the mast to resist the sirens' song; and the Fed Chair as the chaperone who removes the spiked punch bowl just when the party is heating up. See CONTI-BROWN, supra note 21 , passim (repeatedly referring to the "Ulysses/punch-bowl" view of Fed independence); id. at 3 (ascribing the punch bowl metaphor to William McChesney Martin, who served as Fed Chair for nearly two decades).

184 Burton A. Abrams, How Richard Nixon Pressured Arthur Burns: Evidence from the Nixon Tapes, 20 J. ECON. PERSP. 177, 177-79 (2006). 
over the meaning of the constitution. That risk is perhaps least tolerable when, in John Hart Ely's memorable phrase, "the ins are choking off the channels of political change to ensure that they will stay in and the outs will stay out." 185

Ely's justificatory account of judicial review by an independent judiciary translates to the Fed quite tightly. If left to their own devices, incumbent presidents-the ins-will use the levers of monetary policy to stay in and to keep challengers out. The worry also applies to a second-term president, who would be tempted to froth up the economy in the hope of aiding in the election of a successor from the same political party.

In at least one way, Ely's worry about the ins favoring their political interests over the interests of the public in general carries even greater urgency with respect to monetary policy by the Fed than with respect to judicial review by an independent judiciary. Politicians unconstrained by Ely-style representation-reinforcing judicial review will have incentives to rig the political process to give themselves an electoral advantage. Consequently, any policy chosen by the resulting unrepresentative government officials can be said to be bad on process grounds, but the rigging of the system will not systematically lead to substantively bad policy. By contrast, the rigging of monetary policy to benefit incumbents will not only distort electoral results, but will also systematically yield bad policy outcomes because it will bias monetary policy in favor of loose credit, even when tighter credit would be the preferable course on strictly economic grounds. These two concerns-the risk of self-dealing and the tendency of such self-dealing to lead to bad monetary policy-together provide the something extra that we have said is needed to justify Fed independence.

To be sure, "self-dealing" is a relative term. In some sense anything the government does carries a risk of some sort of self-dealing. For example, if the government borrows irresponsibly to fund short-term consumption rather than long-term investment, that choice can benefit incumbents because only the satiated consumers of the here and now vote in the next election. Or the president (with or without congressional authorization or acquiescence) can wage an unnecessary war to create a rally-round-the-flag effect that benefits his or her party

185 ELY, supra note 27, at 103. Ely described political malfunction justifying judicial intervention as occurring either when the ins abuse their power to hold it or when "representatives beholden to an effective majority are systematically disadvantaging some minority out of simple hostility or . . . prejudice[ ]." Id. We focus here on the former rationale. 
in the next election, while imposing future costs on service members, their families, taxpayers, and the general public whose security may be undermined by later blowback.

Nonetheless, the risks of self-dealing with respect to monetary policy are sufficiently different in degree from some other risks of self-dealing to warrant treating them as different in kind. The irresponsible use of monetary policy poses a risk of catastrophic harm, as the history of countries that have experienced hyperinflation confirms. Most other sorts of self-dealing-such as pork barrel spending-may be wasteful and foolish, but do not risk catastrophe.

To be sure, there are risks of catastrophic harm in some other domains. To stick with the clearest example, the use of military force may pose the risk of escalation to nuclear war. The decision to abandon policies favoring alternative energy and instead to tap some potent carbon-based resource could tip the balance towards irreversible and catastrophic climate change. Accordingly, if we were designing American public institutions from scratch, we might conclude that one or more of the agencies responsible for policy in these areas ought to be insulated from direct political control as well. An "independent military" is certainly a conceptual possibility. ${ }^{186}$

However, we are not designing our institutions from scratch. The Commander-in-Chief clause of the Constitution we have plainly requires that the military be subject to direct presidential control. Moreover, even if the Constitution did not rule out an independent military, the risk of catastrophic harm from self-dealing by political actors in the military context must be weighed against other risks. A military not subject to direct political control could increase the risk of a coup d'etat. Even apart from that risk, on the whole, political accountability of the military may actually reduce the risk of catastrophic harm. The Framers' distrust of standing armies ${ }^{187}$ and the decision to give Congress a role in the decision to go to war-together with the Kantian observation that democracies rarely go to war, at

186 Cf. SAMuel P. Huntington, THE SOLDIER AND THE STATE 83-84 (1957) (asserting that the state should encourage "an independent military sphere" so that "multifarious civilian groups" do not "maximize their power in military affairs" by involving the military in political activity).

187 The concern loomed largest among Anti-Federalists. See, e.g., THE ANTIFEDERALIST No. 24 (Brutus), reprinted in THE ANTIFEDERALIST PAPERS 62, 62 (Morton Burden ed., 1965) ("Standing armies are dangerous to the liberties of a people."). The Framers responded by acknowledging the dangers of standing armies but denying that the Constitution would lead to a standing army. See, e.g., THE FEDERALIST Nos. 8, 26, 29 (Alexander Hamilton). 
least against each other ${ }^{188}$-provide reasons to think that an independent military would be, on net, harmful.

Meanwhile and conversely, there is yet another reason for thinking that monetary policy in the hands of directly politically accountable actors would be especially vulnerable to the risk of self-dealing. More than almost any other policy area with systemic effects, monetary policy is opaque to ordinary Americans. If a president "wags the dog" by engaging in politically motivated war, or Congress promotes the coal industry, what is happening will be clear enough to anyone paying attention. By contrast, manipulation of monetary policy can often fly under the public's radar, especially given the diversity of opinion about where interest rates should be set at any particular moment.

In any event, it is not our aim here to show that monetary policy is uniquely suited for an independent agency. If the sorts of factors we have identified that justify independence for the Fed (or other relevant factors) justify the conclusion that, all things considered, some other agencies also ought to be insulated from direct political control, so be it. Our claim is simply that something extra should justify independence for any agency, and that the Fed, more than many agencies operating in other policy areas, satisfies that requirement because of the special risks of self-dealing and catastrophe involved in monetary policy if conducted by politicians or people directly accountable to politicians.

Indeed, far from justifying too many independent agencies, our requirement of a special justification for making an agency independent might prove problematic for many of the existing independent agencies. Independence for some agencies perhaps could be justified on the ground that they address acute versions of the self-dealing concern. For others, one might enlist other sorts of reasons, some of which might also apply to the Fed itself. For example, independent agencies often include representatives from the private sector in order to attain some

188 See Immanuel Kant, Perpetual Peace: A Philosophical Sketch (1795), reprinted in KANT'S POLITICAL WRITINGS 93 (Hans Reiss ed., H.B. Nisbett trans., lst ed. 1970) (setting forth conditions needed to avoid war, including republican government). Modern theorists contest the democratic peace hypothesis. Compare Sebastian Rosato, The Flawed Logic of Democratic Peace Theory, 97 AM. POL. SCI. REV. 585, 588-89 (2003) (critiquing the democratic peace thesis), with Michael W. Doyle, Three Pillars of the Liberal Peace, 99 AM. POL. SCI. REV. 463, 463-66 (2005) (offering a qualified defense of it). Although we agree with Doyle and others that, ceteris paribus, representative government reduces the risk of war, our point here is more limited-namely, that a policy maker or constitution writer could reasonably conclude that control of the military by elected officials reduces the risk of war. 
of the advantages of industry self-regulation. ${ }^{189}$ To render an agency answerable to the private sector, even in part, is necessarily to render it relatively independent of political control. But whether this or some other sort of justification can be found for every independent agency is beyond the scope of this Article. ${ }^{190}$ Our focus is on the Fed, for which the self-dealing rationale apparently suffices.

\section{B. Pathology and Spandrels}

Or does it? Perhaps the standard justification for Fed independence is passé. No longer do we see the Fed fighting to maintain the integrity of the currency against a set of profligate political actors seeking to add temporary froth to the economy in order to boost their standing with the electorate. Instead, as we have noted, the current pattern is just the opposite: many political actors favor tighter monetary policy than the Fed has pursued. Does this role reversal mean that Fed independence can no longer be justified?

We think the answer is no, for there is no reason to think that political actors' current endorsement of monetary (and fiscal) austerity as the path to prosperity is permanent. Institutions like a central bank should be designed with an eye towards the long term, and over the long term the incentives of political actors could once again unduly bias them towards short-term easy money timed to the political cycle at the expense of long-term growth.

Once again, constitutional law provides a useful analogy. In an important article three decades ago, Vincent Blasi argued that in interpreting the First Amendment courts ought to be guided by what he called

189 For a cautious endorsement of the advantages of self-regulation in some contexts, see Michael C. Dorf \& Charles F. Sabel, A Constitution of Democratic Experimentalism, 98 CoLUM. L. REV. 267, 373-88 (1998) (discussing statutes that encourage environmental self-regulation).

190 We also do not address arguments that the Constitution requires all agencies to be subject to the supervision of the president. See, e.g., STEVEN G. CALABResi \& Christopher S. YoO, THE Unitary EXECUTIVE: PRESIDENTIAL POWER From WASHINGTON TO BUSH 10-21 (2008) (describing the modern constitutional debate over the "unitary executive"); Steven G. Calabresi \& Saikrishna B. Prakash, The President's Power to Execute the Laws, 104 YALE L.J. 541, 582 (1994) ('The exclusivity of the power granted by the Executive Power Clause confirms our view that Congress cannot create independent entities under the Constitution .... ."); David Casazza, Note, Liberty Requires Accountability: Checking Delegations to Independent Agencies, 38 HARV. J.L. \& PUB. POL'Y 729, 740-47 (2015) (arguing that delegations to independent agencies violate the nondelegation doctrine). See also sources cited supra, note 92 . We take as given that independent agencies are here to stay. 
the pathological perspective. That is, the overriding objective at all times should be to equip the first amendment to do maximum service in those historical periods when intolerance of unorthodox ideas is most prevalent and when governments are most able and most likely to stifle dissent systematically. The first amendment, in other words, should be targeted for the worst of times. ${ }^{191}$

Blasi explained that even though pathological periods tend to be short-lived, they can do lasting damage, and that the body of free speech doctrine therefore ought to be designed, even in ordinary times, with pathological periods in mind. ${ }^{192}$ Blasi was not so naïve as to believe that judicial adoption of the pathological perspective would utterly prevent pathological periods, but he thought that conscious adoption of the pathological perspective during ordinary times "might help to blunt or delay the impact of some pathological pressures, keep a pathology in certain bounds, or stimulate the regenerative forces that permit a political community to work its way out of a pathological period." 193

It is at least arguable that U.S. free speech doctrine-which is stronger relative to other governmental objectives than free speech protection in any other country-already incorporates something like a pathological perspective. Yet, as Geoffrey Stone has shown, the courts have been powerless to prevent, and have often acquiesced in, unnecessary curtailments of civil liberties when the nation felt threatened. 194 To be sure, many of the episodes Stone details pre-dated modern free speech doctrine, although the post-9/11 measures did not.

In any event, for our current purposes, we do not need to take a position on whether matters would have been still worse had the courts not adopted the pathological perspective in the First Amendment area or, more broadly, whether Blasi's prescription is sound in its own domain. At the very least, there is a logic to Blasi's argument that could be true in any given domain. And that logic translates quite well to monetary policy.

191 Blasi, supra note 24, at 449-50.

192 See id. at 458 (characterizing as "remote" the possibility that "the best way to fortify a constitutional regime against pathological challenge is to develop a strong tradition of adjudication geared to normal times").

193 Id. at 459.

194 See GEOFFrey R. STONE, PERILOUS TIMES: FREE SPEECH IN WARTIME FROM THE SEDITION ACT OF 1798 TO THE WAR ON TERRORISM 4-13 (2004) (describing the U.S. curtailment of civll liberties in response to perceived threats as overreactions). 
Whereas Blasi offered the pathological perspective as an attitude for judges construing the First Amendment, legislators and constitution writers can also take the pathological perspective in designing institutions. Indeed, one might think of a judicially enforceable bill of rights as the product of constitution writers (or amenders) who have taken the pathological perspective. The sort of polity likely to produce a bill of rights that is meant to be taken seriously (by contrast with the rights protections one sees in sham constitutions) ${ }^{195}$ will generally be one that, in normal times, is inclined to respect rights even without the bill of rights. Although Justice Scalia surely overstated the point when he averred that the whole point of a bill of rights is to fortify a society's deep commitments against the possibility that those commitments may be cast aside in a future crisis, ${ }^{196}$ that is certainly part of what a bill of rights does. 197

The same sort of argument justifies Fed independence even in an era when the political branches favor tighter monetary policy than the Fed does. So long as politicians can manipulate the money supply to favor their short-term interests at the expense of the economy's long-term health, an institutional designer who takes the pathological perspective will seek to insulate the central bank from direct political oversight, so as to minimize that risk. Just as Blasi noted that robust pathologically-oriented free speech doctrine will not be sufficient to prevent all overreactions against civil liberties, so too, an independent Fed will not stand up to all political pressure, as the Nixon/Burns episode illustrates. But just as the pathological perspective on free speech can nonetheless be defended on the ground that it may reduce the likelihood and severity of periods of unwarranted invasions of civil liberties, so taking the pathological perspective by designing an independent Fed can be justified on the ground that it reduces the likelihood of political actors bullying the Fed into unwisely increasing the money

\footnotetext{
195 See David S. Law \& Mila Versteeg, Sham Constitutions, 101 CALIF. L. REV. 863, 897-912 (2013) (comparing the rights-protective elements of constitutions with the human rights records of governments).

196 See Antonin Scalia, Common-Law Courts in a Civil-Law System: The Role of United States Federal Courts in Interpreting the Constitution and Laws, in A MATTER OF INTERPRETATION 3, 40-41 (Amy Gutmann ed., 1997) (describing the purpose of a constitution as a hedge agalnst the possibility that the society will "rot").

197 See Michael C. Dorf, The Aspirational Constitution, 77 GEO. WASH. L. REv. 1631, 1633 (2009) (acknowledging that "constitutional rights" sometimes "entrench deep values against future backsliding" even though they "are typically established as the culmination of a struggle to change the status quo, rather than to enshrine well-accepted fundamental values").
} 
supply when the best long-term economic analysis would call for a tight monetary policy.

We would add, moreover, that our concern about self-dealing-with preventing the "ins" from abusing policymaking power to stay in office and to oust their opponents from the offices that the more powerful "ins" currently do not hold-also justifies a concern that politicians could manipulate monetary policy toward inappropriate tightening, as well as easing. As we described above, the classic concern is that incumbents will pump up the economy in order to win elections, but it is in fact possible that politicians could instead decide to strangle the economy as a short-term political maneuver.

Why would a politician want to harm the economy? A long line of political science research has found that, at least in the United States and Britain, the incumbent party's electoral fate is all but sealed by the direction that the economy is taking in the months immediately preceding the election. ${ }^{198}$ That is, it is not a question of whether times are good or bad, but whether the economy is getting better or worse before an election. This means that a savvy politician could decide to manufacture a recession early in her term, in order to set the stage for the economy to experience a robust recovery as the next election looms. President Carter, in fact, was criticized for political naiveté, by essentially running this strategy in reverse. He nominated a Fed chairman in 1979, Paul Volcker, who immediately instituted severe monetary contraction, which meant that Carter and his party faced the electorate in 1980 while presiding over a weakening economy. ${ }^{199}$

We take no position on whether this reductionist view of economic cause and political effect is true or false. Instead, we simply note that some incumbents could believe that it is true, and if those politicians had the ability to control or unduly influence monetary policy, they would have the means and motive to use contractionary monetary policy for political ends,

198 See RAY C. FAIR, PREDICTING PRESIDENTIAL Elections ANd OTHER THINGS 47-55 (2d ed. 2012); Robert S. Erikson. Economic Conditions and the Presidential Vote, 83 AM. POL. SCI. REV. 567, 567-70 (1989); Michael S. Lewis-Beck et al., The Compleat Economic Voter: New Theory and British Evidence, 43 BRIT. J. POL. SCI. 241, 253-61 (2012); Gregory B. Markus, The Impact of Personal and National Economic Conditions on the Presidential Vote: A Pooled Cross-Sectional Analysis, 32 AM. J. POL. SCI. 137, 142-51 (1988).

199 Ann Mari May, Fiscal Policy, Monetary Policy, and the Carter Presidency, 23 PRESIDENTIAL STUD. Q. 699, 708 (1993) (describing the "massive contraction in late 1979 and early $1980^{\prime \prime}$ due to Fed policy, which only turned expansionary in mid1980 , when it was too late to have much effect in time for the presidential election). 
in much the same way that one would usually worry about the inappropriate use of expansionary monetary policy.

Furthermore, the existence of divided government (that is, of one party controlling the presidency, while the other party controls one or both houses of Congress) raises the possibility that one party or the other could exploit a non-independent monetary policy to manufacture pre-election downturns as well as upturns. ${ }^{200}$ For example, in late 2010, Republican Senator Mitch McConnell famously said: "The single most important thing we want to achieve is for President Obama to be a oneterm president."201 There is some controversy over whether McConnell was saying baldly that he would oppose the president no matter what, or instead that he merely meant to say that enacting the Republicans' substantive agenda was contingent on Obama's losing his reelection bid in 2012. ${ }^{202}$ Even on the more generous reading, however, the point is that McConnell wanted Obama to lose the next election. And if monetary policy had been under congressional control-even as a matter of creating stasis, as the Republicans succeeded in doing with regard to fiscal policy after 2010 - the danger would have existed that monetary policy would also have been used to generate an unfavorable political environment for the president in 2012.

Therefore, even in a world where the politicians currently favor tighter monetary policy than the Fed does, they could abuse non-independent monetary policymaking as a way to manipulate political outcomes. Although we view the pathological perspective as sufficient to justify an independent Fed even in an age of austerity, we also can see that the concern about self-dealing is justified even in the current environment.

To say that the pathological perspective ultimately justifies Fed independence, however, is not to deny the value of an

\footnotetext{
200 The party that believed its opponents would be blamed for a weakening economy would have a motive to favor monetary contraction. Usually, the fate of the president's party is thought to depend on the economy, which would give the other party's congressional leaders reason to sink the economy. Where that is not the case, the president would have the motive to impose contractionary policies late in her term, rather than earlier, so that (by hypothesis), her political opponents in Congress pay the political price.

201 Glenn Kessler, When Did McConnell Say He Wanted to Make Obama a "One-Term President"?, WASH. POST (Sep. 25, 2012), http://www.washingtonpost. com/blogs/fact-checker/post/when-did-mcconnell-say-he-wanted-to-makeobama-a-one-term-president/2012/09/24/79fd5cd8-0696-1 1e2-afff-d6c7f 20a83bf_blog.html [https://perma.cc/VC2S-A6NU] (reprinting in full an interview originally published in the National Journal on October 23,2010 ).

202 See id.
} 
independent Fed in ordinary times. Here too we can usefully analogize to an independent judiciary.

Various normative theories of judicial review extend to some but not all of the domain of judicial enforcement of the Constitution. For example, Jesse Choper has argued that judicial enforcement of the Constitution's federalism and separation-of-powers norms creates unnecessary friction with the political branches and that the courts should therefore spend their precious capital on protecting individual rights, where counter-majoritarianism finds its strongest justification. ${ }^{203}$ At the same time, however, Choper does not maintain that the courts act lllegitimately when they enforce federalism and separation-of-powers norms. ${ }^{204}$ Likewise, even as Ely built a theory that justified judicial review to reinforce democracy and protect minority rights, he allowed that the courts can also enforce textual provisions that do neither. ${ }^{205}$

In acknowledging that judicial review can be legitimately exercised across a broader range of cases than those that fall within its core justification, both Choper and Ely were recognizing a basic truth about law and institutions. Just as laws are necessarily over- and under-inclusive with respect to their background justifications, ${ }^{206}$ so an institution may be designed with one purpose in mind, but peculiar features of that design allow it to function well-or poorly-in other settings. Where the design feature is otherwise advantageous, we might borrow a term from architecture and call it a spandrel; where the design feature proves disastrous for some unanticipated reason we might borrow a term from literature and call it a Frankenstein's monster. ${ }^{207}$

In our view, the fact that the Fed has been able to minimize the damage done by insufficiently expansionary fiscal policy since the 2008 economic crisis through loose monetary policy is a happy accident - a byproduct of Fed independence that has been designed to serve a very different purpose. We recognize, however, that people who worry that the Fed's "debasing" of the

203 Jesse H. Choper, Judicial ReView and the National POltical Process $169-70$ (1980).

204 See id. at 381.

205 See ELY, supra note 27, at 76 (accepting that "positive law has its claims, even when it doesn't fit some grander theory").

206 See, e.g., Frederick SCHAUER, PLAYING BY THE RULES 25 (1991).

207 Michael C. Dorf, Spandrel or Frankenstein's Monster? The Vices and Virtues of Retrofitting in American Law, 54 WM. \& MARY L. REV 339 (2012) (arguing that numerous features of American law currently serve purposes for which they were not originally devised). 
currency means that runaway inflation is just around the corner would regard the Fed's use of its independence over the recent period as a very unhappy accident.

If we shared the view of the economic austerians, ${ }^{208}$ we would worry that the recent tendency of the Fed to keep interest rates low calls into question the wisdom of continuing to allow the Fed to act independently. An austerian might still favor Fed independence, however, if she thought that its benefits in pathological circumstances outweighed the harms it inflicts when the Fed's conduct of monetary policy is more expansionary (and thus, to an austerian, dangerous) than the monetary policy favored by political actors. That would be a complex predictive judgment, which could come out the other way. Because we are not austerians, however, to us the calculus looks quite different. The pathological perspective provides the "something extra" needed to justify Fed independence. The happy accident that in normal times Fed independence currently leads to better monetary policy than our era's politics would otherwise appear to allow is simply an added bonus.

\section{An Insider/Outsider Role}

In our view, the foregoing analysis suffices to justify Fed independence even in an age when political actors favor tight monetary policy. Nonetheless, we would call attention to one additional benefit of Fed independence that may be sufficiently substantial as to count as a freestanding justification for Fed independence. Because of the Fed's status as a governmental entity that is not fully answerable to the political branches, it can act as a credible purchaser of government debt. As we described in detail in Part III, that is a useful function in ordinary times and a potentially economy-rescuing function during a crisis.

As we have explained, in a liquidity crisis, a central bank serves the vital role of lender of last resort. In a sovereign debt crisis, a distinctly national central bank serves another function. Recent debt crises in Europe illustrate the point by nega-

208 "Austerian" is a neologism for the view that tight monetary policy during an economic downturn will have a stimulative effect. It playfully combines "austerity" and "Austrian," the latter in reference to "Austrian," that is, Hayekian or antiKeynesian, economics. See, e.g., Paul Krugman, Bully for the Baltics?, N.Y. TimEs: THE CONSCIENCE OF A LiBERAL (Sept. 24, 2011, 9:31 AM), http://krugman.blogs. nytimes.com/2011/09/24/bully-for-the-baltics/ [https://perma.cc/D7RSU4S6] (arguing that austerian cladms for success in Ireland, Latvia, and elsewhere are mistaken). 
tive example. Most prominently Greece-but also other countries struggling to repay sovereign debt-would have a ready solution if they had borrowed in their own currency: they could simply increase the money supply, thereby devaluing the currency, and effectively reducing the value of the debt to levels that could be repaid. To be sure, such a course carries its own rather serious risks, which partly explains why Greece has not (yet) simply abandoned the euro or exited the European Union (EU), but the decision to retain the euro and stay within the EU was undoubtedly influenced by other factors as well.

First and most obviously, because Greece borrowed in euros, a return to and devaluation of the drachma would not by itself affect its debt level. ${ }^{209}$ A country with its own currency and central bank has the advantage of borrowing in its own currency, but once it has accumulated debt in another currency, switching to a national currency does not automatically convert the debt. Thus "Grexit" 210 can only be accomplished by a default (or a negotiated haircut) on debt owed in euros, with an attendant increased cost of obtaining future credit. ${ }^{211}$

Second, restarting a national currency would entail substantial transition costs. As soon as people learned of an impending currency shift, many of them would seek to withdraw their euros from Greek financial institutions before their money was converted into drachmas of uncertain and likely declining value. Bank runs would result. Indeed, something very much like this happened in Greece in the summer of 2015 when a Grexit began to be taken seriously as a possibility. ${ }^{212}$

And finally, it appears that Greece faced the possibility of political and national security consequences if it abandoned the euro. ${ }^{213}$ Thus, the fact that no Grexit has (yet) occurred

209 Leslie Shaffer, Why the Drachma Can't Save Greece: Goldman, CNBC (Mar. 3, 2015, 11:35 PM), http://www.cnbc.com/2015/03/03/why-the-drachma-cant -save-greece-goldman.html [https://perma.cc/Y7J5-QAMM].

210 "Grexit" is a neologism signaling the idea of Greece's exit from the Euro area. It was coined by economists Willem Buiter \& Ebrahim Rahbari, Global Economics View: Rising Risks of Greek Euro Area Exit, CITIGROUP (Feb. 6, 2012), http://willembuiter.com/Citi44.pdf [https://perma.cc/QHS6-BVDH].

211 Countries that default on their sovereign debt are not forever banished from credit markets but, ceteris paribus, they pay an interest premium. See generally ODETTE LIENAU, RETHINKING SOVEREIGN DEBT (2014) (finding little historical evidence for a categorical norm punishing sovereigns for all defaults).

212 See Robert Peston, Greek Banks 'Days Away from Running Out of Cash,' BBC NEws: BusinEsS (July 5, 2012), http://www.bbc.com/news/business33403008 [https://perma.cc/U5RQ-4ZJ6].

213 See Naftali Bendavid \& Katerina Voutsina, Possible Greek Exit from Eurozone Sparks Wider Geopolitical Concerns, WALL ST. J. (July 9, 2015, 7:10 AM), http://www.wsj.com/articles/possible-greek-exit-from-eurozone-sparks-wider- 
hardly shows that Greece would not have been better off had it never abandoned the drachma for the euro in the first place.

The Greek case illustrates the value of a national central bank when a country desperately needs credit, but it does not show that the central bank must be independent. On the contrary, one might think that it shows the value of a central bank that does the bidding of the elected leaders of the government. From the Greek perspective, the problem with the European Central Bank in the current era is that it is too independent of the government of Greece.

It does not follow, however, that a central bank should be subject to direct political control. For one thing, as we argued above, the pathological perspective warrants some degree of independence to address the structural risk of self-dealing. Moreover, even in a sovereign debt crisis, independence is valuable.

Consider the debt-ceiling scenario we discussed in Part III. The immediate impact of a Fed policy of buying technically illegal bonds would be to enable the government to pay its bills and thus to avoid defaulting on its legal obligations; buying those bonds buys time for the political actors to come to their senses.

But a Fed policy of buying such bonds would also have a second, arguably more important, impact. It would calm financial markets. Seeing the Fed purchasing the new bonds would reassure holders of existing (pre-crisis) bonds that their assets remain valuable. The policy would thus prevent a massive selloff of Treasuries that would further raise the government's cost of borrowing and might even threaten the status of the dollar as a reserve currency.

Crucially, however, the Fed can only play this market-pacification role if the Fed is seen as a credible, responsible actor. Independence greatly strengthens that perception. Imagine how markets would react if a politically controlled central bank were to buy new bonds in a debt-ceiling crisis. Seeing that the administration's "own" central bank was complicit in the issuance of debt-ceiling-violating bonds, markets would hardly be

geopolitical-concerns-1436440251 [https://perma.cc/KZ7S-9CMZ]; Maria Petrakis, Keeping Greece in the Euro May Have Nothing to Do with Finances, BLOOMBERG BUSINESS (June 11, 2015, 7:01 PM), http://www.bloomberg.com/news/ articles/2015-06-11/keeping-greece-in-the-euro-may-have-nothing-to-do-withfinances [https://perma.cc/D55W-Q9ZT]; Nicholas Sambanis \& Ioannis Galariotis, Is GREXIT a Threat to Greece's Security?, WASH. POST: MONKEY CAGE (May 3, 2015), https://www.washingtonpost.com/news/monkey-cage/wp/2015/05/ 03/is-grexit-a-threat-to-greeces-security [https://perma.cc/8D64-RX4W]. 
reassured of the real value of those bonds. Precisely because the actual Fed is insulated from political control, it can act as a credible counterparty to the government when the government issues debt.

The point is easiest to see in a crisis, but it also holds true in ordinary times. As we explained above, money itself has no inherent value; it derives its value from the fact that everyone expects everyone else to treat it as valuable. ${ }^{214}$ A central bank that acts independently of the political branches of government can credibly signal to the public that the money (whether in the form of currency or bonds) the government issues indeed has value. A central bank that is-and is therefore perceived as-a mere tool of the political branches of government can make no such commitment.

Finally, the Fed's political independence is also essential to allow it to fulfill its key function as the agency that adjusts monetary policy in response to the political branches' changes in fiscal policy. A common view among economists is that, in normal times, the Fed should adjust monetary policy to offset the expansionary or contractionary effects of fiscal policy. For example, when politicians decide that it is a good idea to reduce annual deficits or to run surpluses and thus pay down some of the government's debt, the associated government spending cuts or tax increases acting on their own would tend to shrink the economy. If the Fed has room to cut interest rates, however, ${ }^{215}$ it can prevent the economy from contracting in response to the fiscal consolidation.

Crucially, if the Fed were not independent, it would be much more difficult to coordinate monetary and fiscal policies, and to guarantee to all relevant decision makers that the amount and timing of the offsetting policy changes will be carried out without political interference. But if the Fed can credibly guarantee to wavering members of Congress, who might otherwise worry that their votes for tax increases or spending cuts could result in job losses, that monetary policy will be used to offset those effects, it would be easier for those members of Congress to vote for fiscal contraction. Although there are plenty of situations in which particular tax increases or spending cuts might be unwise, the Fed's ability to remove macroeconomic concerns from the conversation allows the po-

214 See supra text accompanying notes 49-56.

215 It was precisely because the Fed had already cut interest rates to zero in 2008 that the fiscal austerity policies were so damaging in the U.S. and Europe. See Bd. of Governors of the Fed. Reserve Sys., supra note 138. 
litical branches to discuss fiscal policy matters on their own merits. If, for example, the country were emerging from a severe recession in which the government had instituted fiscal measures that were intended to be temporary, the Fed's independence would ease the transition back to normal operations, thus preventing otherwise unnecessary temporary spending programs from becoming effectively permanent.

Similarly, if the political branches were to determine that there should be a large increase in spending (for example, a multiyear program to rebuild the nation's infrastructure), there might be serious concern that such an expansionary fiscal policy could generate inflation. Knowing that the Fed would prevent that from happening would again allow politicians to evaluate such a policy only on its merits or demerits.

In short, even the political branches have good reason to want the Fed not to be a tool of those same political branches. Just as it is important to the health of the financial system (and ultimately, therefore, to the overall economy) that the public not view the Fed as being part of the political mix, it is important that the politicians themselves know that their decisions on fiscal policy will be paired with appropriately non-politicized monetary policy decisions. Only an independent Fed can credibly make such a guarantee.

\section{CONCLUSION}

In response to repeated market panics in the nineteenth and early twentieth centuries, Congress created the Federal Reserve System in 1913 to serve as the nation's central bank. The Fed's core function is to be the "lender of last resort," that is, to intervene when market contagions create runs on banks and to counter other market pathologies that could, if unchecked, threaten the viability of the entire financial system and thus the economy. Because of the surpassing importance of that core function, Congress granted the Fed substantial independence in setting policy and in implementing the market interventions that it deems necessary. Being the lender of last resort, in turn, requires the Fed either to set monetary policy after a crisis has passed (to offset its actions during the crisis), or at least to coordinate with any other entity that Congress might endow with the power to set monetary policy (including Congress itself). Congress wisely chose to give the Fed that power directly.

The Fed's performance during and after the 2008 market collapse was exemplary. It was not only the Fed's political in- 
dependence that allowed it to succeed; in addition, its functional and perceived position as being "outside the government" allowed the Fed to calm the markets and rescue the economy from what could have become a second Great Depression. The extent of the Fed's actions in the 2008 crisis, and the inability of any other public or private entity to intervene successfully in the crisis, made Congress's decisions in setting up the Fed as a powerful entity freed from day-to-day political considerations look prescient.

Nonetheless, the Fed's recent actions have led to vituperative attacks on its independence. This is hardly the first time that the Fed or its predecessors have been targeted, but the current round of attacks has included extreme calls to inject political considerations into the Fed's decision-making and attempts to intimidate Fed decision makers to set aside their own best judgment in favor of the Fed's attackers' policy preferences.

In this Article, we have argued that the Fed should not be rendered more directly accountable to political actors. The very real possibility of a near-future crisis that would be caused by the political branches' failure to increase the federal debt ceiling shows how the Fed's unique structure makes it the only actor that could minimize the damage in such a crisis, both because of the Fed's ability to act as lender of last resort and its power to act exactly when needed. We also warn, however, that pushing the Fed into the role of last-minute savior in such a crisis risks exposing it to accusations that it has taken sides in a political conflict. In proving that its political independence is essential, the Fed might endanger that very independence.

Even if we are wrong about how that particular hypothetical crisis would play out, our broader goal is to explain how the Fed's political independence enables it to act, during good times as well as bad, as an essential bulwark against policy making that would harm the financial system and the economy as a whole. We note that the Fed's "insider-outsider" role provides the latitude for the Fed to take actions that would safeguard financial markets, whereas any other agency of government that tried to engage in those same actions would more likely fail (and possibly even make matters worse).

In addition, drawing an analogy to the Article III judiciary, we argue that institutional independence is easiest to justify when it prevents the "ins" from abusing power for political advantage. We thus show that the Fed's independence protects the public from politicians' efforts to use the especially tempt- 
ing levers of monetary policy to entrench themselves in power. We further argue that the Fed's independence allows politicians to undertake policy initiatives with the knowledge that their actions will not be undermined by politically motivated activity at the Fed. In both good times and bad, therefore, an independent-but-ultimately-accountable Federal Reserve is an essential guardian of both the economy and the political system. 